\title{
Buildout and Upgrade of Central Emergency Generator System, Generators 3 and 4 Electrical Installation
}

Gary D. Seifert

G. Shawn West

Kurt S. Myers

Jim Moncur

July 2006

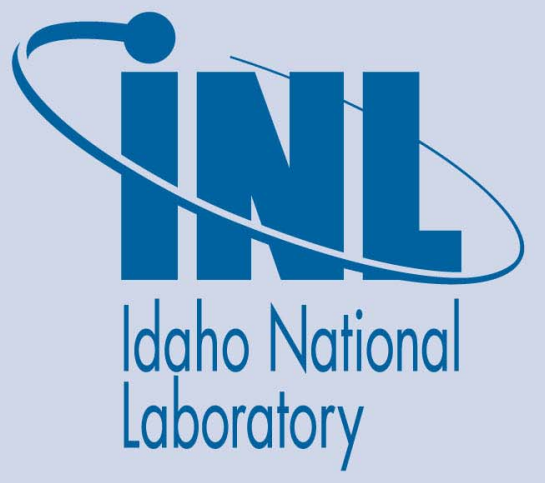

The INL is a U.S. Department of Energy National Laboratory operated by Battelle Energy Alliance 
INL/EXT-06-11603

\title{
Buildout and Upgrade of Central Emergency Generator System, Generators 3 and 4 Electrical Installation
}

\author{
Gary D. Seifert \\ G. Shawn West \\ Kurt S. Myers \\ Jim Moncur \\ July 2006 \\ Idaho National Laboratory \\ Idaho Falls, Idaho 83415 \\ Prepared for NASA DFRC \\ NASA Project Number \\ and for the \\ U.S. Department of Energy \\ Under DOE Idaho Operations Office \\ Contract DE-AC07-05ID14517
}




\section{BUILDOUT AND UPGRADE OF CENTRAL EMERGENCY GENERATOR SYSTEM, GENERATOR 3 AND 4 ELECTRICAL INSTALLATION}

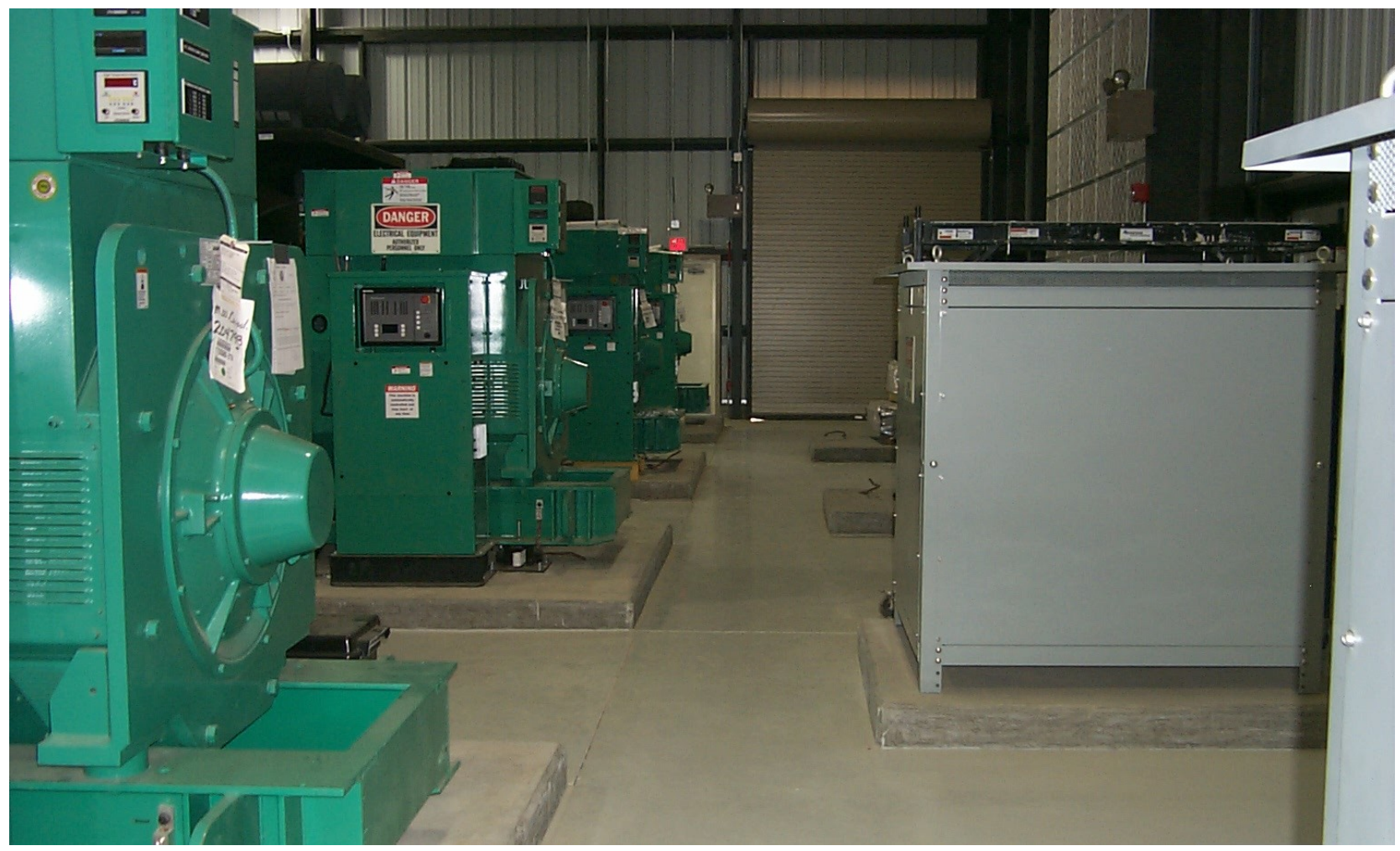

Prepared for NASA DFRC

For NASA Project \#?????

By Idaho National Laboratory

Under DOE Work Authorization \#DE-AC07-05ID14517 


\section{PROJECT TABLE OF CONTENTS}

DIVISION 01 - GENERAL REQUIREMENTS

$01000 \quad$ SUMMARY OF WORK

01010 STANDARD REQUIREMENTS

01330 SUBMITTAL PROCEDURES

01401 CONTRACTOR QUALITY CONTROL

01411 GENERAL SAFETY REQUIREMENTS

01420 SOURCES FOR REFERENCE PUBLICATIONS 


\section{$\underline{\text { SECTION 01000-SUMMARY OF WORK }}$}

\section{PART 1 - GENERAL}

\subsection{SUMMARY}

The work to be performed under this project consists of providing the labor, equipment, and materials to perform "Buildout and Upgrade of Central Emergency Generator System, Generator 3 and 4 Electrical Installation" for the National Aeronautics and Space Administration at the Dryden Flight Research Center (NASA/DFRC), Edwards, California 93523. All modifications to existing substations and electrical distribution systems are the responsibility of the contractor. It is the contractor's responsibility to supply a complete and functionally operational system. The work shall be performed in accordance with these specifications and the related drawings.

The work of this project is defined by the plans and specifications contained and referenced herein. This work specifically includes but is not limited to the following:

Scope of Work - Installation

1. Install all electrical wiring and controls for new generators 3 and 4 to match existing electrical installation for generators 1 and 2 and in accordance with drawings. Contractor shall provide as-built details for electrical installation.

2. Install battery charger systems for new generators 3 and 4 to match existing battery charging equipment and installation for generators 1 and 2 . This may require exchange of some battery charger parts already on-hand. Supply power to new battery chargers from panel and breakers as shown on drawings. Utilize existing conduits already routed to generators 3 and 4 to field route the new wiring in the most reasonable way possible.

3. Install electrical wiring for fuel/lube systems for new generators 3 and 4 to match existing installation for generators 1 and 2. Supply power to lube oil heaters and fuel system (day tanks) from panel and breakers as shown on drawings. Utilize existing conduits already routed to generators 3 and 4 to field route the new wiring in the most reasonable way possible. Add any conduits necessary to complete wiring to fuel systems.

4. Install power to new dampers/louvers from panel and breakers as shown on drawings. Wiring shall be similar to installation to existing dampers/louvers. Utilize existing conduits already routed to louver areas to field route the new wiring in the most reasonable way possible. Add any conduits necessary to complete wiring to new dampers/louvers.

5. Install power to jacket water heaters for new generators 3 and 4 from panel and breakers as shown on drawings. Utilize existing conduits already routed to generators 3 and 4 to field route the new wiring in the most reasonable way possible. 
6. Install new neutral grounding resistor and associated parts and wiring for new generators 3 and 4 to match existing installation for generators 1 and 2. Grounding resistors will be Government Furnished Equipment (GFE).

7. Install two new switchgear sections, one for generator \#3 and one for generator \#4, to match existing generator \#1 cubicle design and installation and in accordance with drawings and existing parts lists. This switchgear will be provided as GFE.

8. Ground all new switchgear, generators 3 and 4 , and any other new equipment to match existing grounding connections for generators 1 and 2, switchgear and other equipment. See drawings for additional details. Grounding grid is already existing. Ensure that all grounding meets National Electrical Code requirements.

9. Cummins DMC control for the generator and switchgear system shall be modified to make the control system more similar to a standard Cummins control format. The intent is to try to make only minor modifications, not major changes or a total overhaul, to the existing PLC/HMI programming. Any functions in the DMC program that do not currently work properly (see more details below) shall be modified either in the program or wiring to the DMC, whatever is necessary, to enable those functions to work properly under all testing and operational conditions. Specific items to be addressed include, but are not limited to:

- All status points that are critical to system control shall be hardwired into the DMC system instead of routing through Alstom relay communications channels and cables (see additional details below, i.e. breaker status " $a$ " contacts should be directly wired in for all breakers associated with generator system, including breakers in the substation yard, etc.)

- Remote permissive switch and trip and close arrangements for all the breakers in the substation yard 12.47 KV switchgear need troubleshooting and modification to ensure proper operation. Permissive switch status shall be disconnected from Alstom relays and wired directly into Cummins DMC system. See drawings for additional details.

- Any DMC inputs that are delayed due to communication cable and relay timing shall be used only for status and monitoring, not control.

10. Wire/connect an "a" contact from each feeder breaker in the existing substation yard 12.47 KV switchgear into the Cummins DMC control system and modify program to utilize and indicate breaker open and closed status using this hardwired point instead of the point previously routed through the Alstom relays and communication cables. Cummins DMC and PLC programming shall only use hardwired points for control commands. No inputs that come through communication channels shall be used for control (communication delays have caused problems with previous attempts). See drawings for additional details.

11. Remote permissive switch arrangements for all the breakers in the substation yard $12.47 \mathrm{KV}$ switchgear need troubleshooting and modification to ensure proper operation. Complete all wiring and DMC programming of previously started permissive arrangement to make this function fully operational for each breaker. See drawings and PLC program for additional details. 
12. Re-wire contact from new LS1-X breaker charged relay directly to the Cummins DMC control panel/system instead of through the Alstom relay communication loop for each feeder breaker in the substation yard $12.47 \mathrm{KV}$ switchgear. Modify DMC programming accordingly to properly indicate breaker charged status of the feeder breakers. See drawings and PLC program for additional details. Breaker charged status cannot be derived (without some significant modifications) from the mains and tie breakers in the substation yard switchgear because of the different breaker type and control arrangement, so breaker charged status from these three breakers will not be required for this project.

13. Specific items to be addressed and corrected, identified during commissioning tests:

- Feeder breakers \#4 and \#10 status indications on the DMC control display were incorrect. Showed closed when they were in the open position. Feeder breakers \#2 and \#3 also indicate incorrectly. Check wiring and programming and correct. This problem may be alleviated when breaker status is directly wired into the DMC from the "a" contacts instead of through the Alstom communications loop.

- Test to switch from source M-1 to M-2 did not work. Check wiring and programming and correct.

- Test to switch from source M-2 to M-1 did not work. Check wiring and programming and correct.

- Mode switch Manual operation did not work as expected, must use the computer to finish switch. Check wiring and programming and correct.

- Circuit breaker PHB was switched from Manual to Auto and the breaker opened. Reason is believed to be that the nametags were not labeled correctly. Check wiring and programming and correct.

- Feeder breakers 5,6 and 7 did not operate in the Auto mode (Load Shed). Check wiring and programming, submit possible solutions, and correct if possible. It is possible that this becomes corrected by breaker status improvements.

- Feeder breakers could not be closed by the PLC. Check wiring and programming and correct. The breaker status improvements should contribute to solution of this problem.

14. Contractor shall verify that generator building fire alarm logic is in the Fire Alarm Panel (FAP), and that only one shutdown contact/signal shall go between the FAP and the generator control PLC to enable generator shutdown. If any programming for this fire alarm logic is in the generators PLC, it shall be removed and transferred to the FAP.

15. The 79, 60 and 47 relay devices and associated wiring and time delay relays shall be removed from the Substation $1612.47 \mathrm{kV}$ switchgear cubicles M1, M2 and MBT. Blank cover plates shall be installed. See drawings for additional details.

16. Contractor shall reprogram Alstom relays (Substation $1612.47 \mathrm{kV}$ switchgear) and Cummins DMC for only one Alstom trip status from each Alstom RL0 output. That output shall close upon any type of trip function programmed into the Alstom relay. Coordinate with NASA 
engineering to verify that new Alstom relay programming incorporates the proper trip

functions and settings based on previous relay coordination study.

17. Contractor shall calibrate any new relays installed as part of this project.

18. Ensure that all electrical wiring and grounding meets National Electrical Code requirements.

19. All switchgear and cable referred to as $12.47 \mathrm{kV}$ shall be rated to $15 \mathrm{kV}$.

\section{Bid Additives:}

None at this time.

\subsection{NASA DESIGN CRITERIA}

1.2.1 Background: The NASA-Dryden Central Emergency Generator System currently has two (2) $1.5 \mathrm{MW}$ generators connected to a double-ended $12.47 \mathrm{kV}$ substation. The generator system and building has physical space for two additional generators. NASA-Dryden has procured two additional generators and associated switchgear. This equipment will be provided as Government Furnished Equipment (GFE).

1.2.2 General Scope Requirements for "Buildout and Upgrade of Central Emergency Generator System, Generator 3 and 4 Electrical Installation"

1.2.2.1 Install 2 - 1.5 Megawatt generators and related switchgear, paralleling equipment, synchronization equipment, associated electrical wiring/equipment and ancillary mechanical support equipment to increase the total generating capacity of Building 4872 to 6 Megawatts. Mechanical portions of this upgrade project will be installed as part of a separate contract.

1.2.2.2 Simplify existing generator control system. The upgraded control system will be simple, reliable, and easy to understand and maintained by factory service technicians and on-site maintenance personnel.

1.2.3 Bldg 4872/Substation 16 Control System Reprogramming and Hardware Reconfiguration (additional information for item 1.2.2.2 above)

1.2.3.1 The control system will be a standard Cummins-Onan control schema. Upon loss of power, all four (4) 1.5MW generator will, start, synchronize and assume facility load at Substation 16.

1.2.3.2 Remove existing automatic load shedding software routines. The $12.47 \mathrm{KV}$ branch feeders at Substation 16 will not be part of the controls decision-making process. Only Feeders 5, 6, and 7 (Thermostructures/heat soak) will be disconnected upon loss of SCE power (normal power) and reconnected when SCE power is re-gained. The final contract 
shall either modify existing PLC programming (preferred) or completely re-write PLC program.

1.2.3.3 The operation of the control system will remain essentially as defined in the original specifications "Rehabilitation and Modification of Central Emergency Generator System, NASA-Dryden, EDM-1644, dated 05/24/02, Section 16344”. The following sub-sections will be omitted:

1.2.3.3.1 Section 16344, 2.1.2.7 "Automatic Priority Load Control" - remove.

1.2.3.3.2 Section 16344, 2.1.2.8 "Automatic Operation - Fault Isolation"

1.2.3.3.3 Section 16344, 2.1.2.9 "Automatic Operation - Single Phased Source

1.2.3.3.4 Section 16344, 2.1.2.10 "Automatic Operation - Faulted Bus"

The protective relays on individual breakers will provide fault protection and isolation. The PLC shall not be used to reclose on fault conditions. Existing graphics interface shall be re-programmed to accommodate deletions and changes.

1 2.3.4 The Quantum PLC will interactively make decisions only based on the status of 12.47KV M1, M2 and TIE breakers. These breakers/status are currently hardwired to Quantum PLC. Existing Current and Voltage from M1 and M2 will also be used as inputs and are currently hard-wired.

1.2.3.5 There are three third party network loops that provide translated data to the Quantum PLC. After this upgrade is completed, these network loop interfaces to Quantum PLC shall only be used for monitoring. All programming using these networks for control input or output shall be removed.

1.2.3.5.1 Sub 16 GEC-Alstom relays - PLC and HMI programming (for these devices) that uses this network data for control should be changed to monitoring only. Existing hardwired trip and health status inputs for these relays may remain in the program only for display/monitoring (no control).

1.2.3.5.2 Sub 16 NEXUS relays - PLC and HMI programming (for these devices) that uses this network data for control should be changed to monitoring only.

1.2.3.5.3 Bldg 4872 GEC-Alstom relays - PLC and HMI programming (for these devices) that uses this network data for control should be changed to monitoring only. Existing hardwired status inputs for these relays may remain in the program only for display/monitoring (no control).

\subsubsection{Additional Hardware Modifications}

1.2.4.1 Upon activation of permissive override switches, all manual breaker functions shall be restored, including pistol grip operation.

1.2.4.2 Ensure proper operation of Quantum Hot-swap computer or remove this 
capability.

\subsubsection{References}

1.2.5.1 Original Facility Requirements Document (FRD) "Rehabilitation and Modification of Central Emergency Generator System, NASA-Dryden"

1.2.5.2 Rehabilitation and Modification of Central Emergency Generator System, NASADryden, EDM-1644

1.2.5.3 Rehabilitation and Modification of Central Emergency Generator System, NASADryden, Various As-builting documentation

\subsubsection{Various documentation of wiring systems}

\section{$\underline{1.3 \text { PROJECT PHASES }}$}

The contractor shall perform the work in, and provide scheduling for four (4) distinct 'phases' of the project. After completion of each phase of construction, a final inspection will be performed by the Government prior to work commencing in the next phase. Once the work in one phase is completed and accepted by the Government, the Contractor will be issued a Notice to Proceed for the next phase establishing start and completion dates reflecting the number of days allowed per phase as shown in Paragraph 1.4 " Phased Construction Schedule".

The order of phase execution is:

1-Field Investigation

2-Submittal and Scheduling Phase

3-Construction and Installation Phase

4-Documentation submittals

1.3.1 Field investigation: Includes the site verification and location of work area, storage areas, conduit and wiring routing, switchgear layouts and details, etc. The Contractor shall submit a formal 'differing site conditions' report to the Contracting Officer for review. When all conditions have been satisfied the C.O. may issue a Notice to Proceed to Phase two (2) 'Design Submittal Phase'.

1.3.2 Submittal and Scheduling phase: Includes the submittal of all major components, material, design drawings showing specific installation, proposed programming and control changes, and a detailed construction schedule minimizing outages required to complete the project. The contractor must have an approved construction schedule prior to commencing any site work. Guideline notes for the construction schedule are included on the drawings. Upon approval of all required submittals, the C.O. may issue a NTP to Phase three (3) 'Construction and Installation'. 
1.3.3 The Construction and Installation shall be sequenced with other area projects to ensure minimum customer impact. Construction includes the installation of all electrical wiring, connections, equipment and programming additions and changes for the addition of new generators 3 and 4 to the existing generator system at Sub 16, and installation of all approved components, wiring, terminations, testing and operations to complete an operational system.

1.3.4 Documentation Submittals: The contractor is responsible for correcting all changes (as build drawings) that may have occurred during construction and providing final submittals and contract drawings with all corrections. Contractor shall validate and submit formal as build drawings and Operations \& Maintenance (O\&M) manuals and

Training curriculum \& lesson plans for approval. All as build drawings shall be delivered in electronic media, in AutoCAD R14 format with all entities in model space and all external references blinded to the drawing. Each drawing will be autonomous containing all block, functions, macros and entities.

\subsubsection{Base Bid}

The contract is structured with the scope of work described in Section 1.1 above as all base bid work.

\subsection{SUBMITTALS}

All submittals shall be supplied in accordance with Section 01330 "Submittal Procedures" in sufficient detail to show full compliance with the specification:

SD-18 Records

Sequence Plan and Procedures shall be submitted in accordance with Paragraph 1.6 "PHASE CONSTRUCTION SCHEDULE “ of this section. The Construction progress schedule/sequence plan shall be submitted and continually updated as necessary.

\section{$\underline{1.5 \text { CONTRACT DOCUMENTS }}$}

The following drawings and documents accompany this specification and are a part thereof:

a. Drawings: " Buildout and Upgrade of Central Emergency Generator System", (Drawing Number) sheets T-1, A-2, M-7 and E-1 through E-48.

b. Reference Documents:

(1). NASA Substation 16 diagrams and schematics, existing as-built drawings for Emergency Generator System. 
Five sets of contract drawings, documents, and specifications will be furnished to the Contractor without charge. One copy of the Reference document(s) will be furnished after contract award. The Contractor shall immediately check furnished drawings and documentation and notify the Government of any discrepancies.

\subsection{PHASED CONSTRUCTION SCHEDULE}

The contractor will commence and complete all work within the overall project schedule of 170 days. Liquidated damages (LDs) will be assessed for Contractor delays in the amount of \$128.00 per day.

The following reflects the number of calendar days that will be allowed.

Task

NTP-Mobilize Site Calendar Days

Field Investigation Phase

021

Submittal and scheduling 030

Construction/installation Phase $1 \quad 95$

Documentation (Asbuilts, O\&M Manuals) 014

Total

170

\section{$\underline{1.7 \text { WORK HOURS }}$}

All work that can performed without adversely affecting the NASA facilities operation shall normally be performed during normal duty hours, which are from 07:30a.m. to 04:00p.m. Normal duty hours are defined in Section 01010 "Standard Requirements" Paragraph 1.8 "Normal Duty Hours". Work may be scheduled outside normal working hours, on Weekends and Government holidays on a case by case need basis, however the Contractor must obtain approval from the Contracting Officer fourteen (14) days in advance to work on weekends or holidays. Work that requires a power outage or that may interfere with normal on-going work by NASA and other contractors must be performed outside normal duty hours at no additional cost to the government.

The Contractor shall allow for a maximum of ten (10) days per year where construction activity is not permitted because NASA facilities are closed.

\subsection{GOVERNMENT-FURNISHED PROPERTY}

Government Furnished Equipment (GFE) to be installed by the contractor for this contract includes generators 3 and 4 and generator local control panels. GFE will include generator grounding resistors and new switchgear cubicles for generators 3 and 4 . The Contractor will be held responsible for the correct, safe and efficient operation of the equipment that will require the services of experienced and qualified Electricians. The Contractor will be responsible for all 
installation, anchoring, bus work, grounding, control wiring, power cable connections and terminations, and testing of this equipment.

\subsection{REUSED MATERIAL, EQUIPMENT}

All material and equipment that may be reused is designated on the drawings. All equipment or components removed by this contract shall be turned over to the Contracting Officer who may at his option require the contractor to remove from the site with proper disposal (Ref. Section 01010 Para 1.1.7 SALVAGE MATERIAL AND EQUIPMENT).

\subsection{REQUIRED OPERATIONAL TEMPORARY EQUIPMENT}

The Contractor is responsible for providing electrical, pneumatic, and other power utilities, including telephones, to operate all equipment necessary to complete the project (Ref. 01010 Para 1.13 TEMPORARY UTILITIES). The contractor may however utilize existing electrical power where available and as appropriate and approved by the contracting officer. A formal request is required for specific connection to Government facilities.

\subsection{PROPRIETARY EQUIPMENT, MATERIALS, SYSTEMS}

There are no known proprietary products required by this contract with the exception of parts to match existing generator installation and equipment.

\subsection{PROGRESS SCHEDULE}

Reference: Section 01010 STANDARD REQUIREMENTS Paragraph 1.5 (PROGRESS

SCHEDULE).

PART 2 PRODUCTS (Not Applicable)

PART 3 EXECUTION (Not Applicable)

END OF SECTION 01000 


\section{SECTION 01010-STANDARD REQUIREMENTS}

\section{PART 1 - GENERAL}

\subsection{SUMMARY}

The requirements of this section apply to, and are a component part of, each section of the specifications. The following are standard requirements in construction contracts at the National Aeronautics and Space Administration Dryden Flight Research Center (DFRC).

\subsection{REFERENCES (Not Applicable)}

\subsection{SUBMITTALS}

The following shall be submitted in accordance with Section 01330 "Submittal Procedures" in sufficient detail to show full compliance with the specification:

SD-01 Preconstruction Submittals

Progress Schedule shall be submitted in accordance with Paragraph 1.5 "PROGRESS SCHEDULE".

Schedule of Prices shall be submitted in accordance with Paragraph 1.6 "SCHEDULE OF PRICES".

SD-06 Test Reports

Daily Report to the Inspector shall be submitted in accordance with Paragraph 1.4 "DAILY REPORT TO THE INSPECTOR".

The following shall be submitted in accordance with Paragraph 1.18 "STARTING OF SYSTEMS":

Test Procedures

Functional Test Report

SD-07 Certificates

Contractor's Invoice shall be submitted in accordance with Paragraph 1.7 "CONTRACTOR'S INVOICE".

Salvage Material Records shall be submitted in accordance with Paragraph 1.17 "SALVAGE MATERIALS AND EQUIPMENT".

SD-10 Operation and Maintenance Data 
Operation and Maintenance Manuals shall be submitted in accordance with Paragraph 1.20 "OPERATION AND MAINTENANCE DATA".

The following shall be submitted in accordance with Paragraph 1.20

"OPERATION AND MAINTENANCE DATA":

Preventive Maintenance and Inspection Instructions

Posted Instructions

SD-11 Closeout Submittals

As-Built Drawings shall be submitted in accordance with Paragraph 1.21 "ASBUILT DRAWINGS".

\subsection{DAILY REPORT TO THE INSPECTOR}

The Contractor shall deliver to the Contracting Officer a "Daily Report to the Inspector" on a form furnished by the Contractor. The form shall be completed daily and delivered to the Contracting Officer by 10:00 am on the next work day. Data to be reported shall include:

a. Number of hours worked for the day.

b. Cumulative total of hours worked on the contract.

c. Number of workers by classification for the day.

d. Work activities completed for the day.

e. The move-on and move-off of construction equipment during the day, and whether furnished by the Contractor, Subcontractors, or the Government.

f. Material and equipment delivered to the site during the day.

g. Any significant events on the site during the day.

\section{$\underline{1.5}$ PROGRESS SCHEDULE}

The Contractor shall prepare and submit to the Contracting Officer for approval a practicable schedule showing the order in which the Contractor proposes to perform the work, and the dates on which the Contractor contemplates starting and completing the major salient features of the work, including acquiring materials and equipment. The schedule shall be in the form of a progress chart of suitable scale to indicate appropriately the percentage of work scheduled for completion by any given date during the period. The Contractor shall:

a. Submit the progress chart in three copies to the Contracting Officer for approval no later than 15 days after notice to proceed.

b. Prepare the progress chart in the form of a bar chart utilizing a comparable format acceptable to the Contracting Officer.

c. Include no less than the following information on the progress chart: 
1. Break out by major headings for primary work activity.

2. A line item break out under each major heading sufficient to track the progress of the work.

3. A line item showing final contract tasks which include punch list, cleanup, O\&M data, and As-Built drawings.

4. The estimated cost and percentage weight of total contract cost for each line item on the chart. This shall be consistent with the Schedule of Prices.

5. Separate line items for submittal preparation and reviews. These shall be consistent with the "Schedule of Submittals" required in Section 01401, "QUALITY CONTROL". Submittal preparation and reviews are to show no associated costs.

6. Separate line items for mobilization and demobilization.

d. Update the progress schedule in 3 copies every 30 days throughout the contract performance period. The updated schedule shall be submitted with the monthly payment request.

\subsection{SCHEDULE OF PRICES}

Within 15 days after notice to proceed, the Contractor shall submit, for approval by the Contracting Officer, on a form furnished by the Contractor, a Schedule of Prices consisting of a detailed cost breakdown of the contract price for each definable feature of work. This shall include work item quantities, unit material and labor costs, and extended sub-totals. Unit costs shall include all project overhead and profit. Line items for Bonds, Mobilization and Demobilization are allowable. All cost items shall be accurate and reasonable and reflect pricing figures from the subcontractors actually performing the various items of work. Progress payments shall be evaluated and paid from the approved Schedule of Prices.

\subsection{CONTRACTOR'S INVOICE}

Requests for payment in accordance with the terms of the contract shall consist of:

a. The Contractor's invoice on the form furnished by the Contracting Officer for this purpose, shall show in summary form the basis for arriving at the amount of the invoice.

b. The contract performance statement on the form furnished by the Contractor for this purpose and consistent with the approved Schedule of Prices, shall show in detail the estimated cost percentage of completion and value of completed performance for each definable feature of work. The format, content, and number of copies required will be prescribed by the Contracting Officer and will be subject to his/her approval.

No separate payments will be made for protection efforts necessitated by the safety provisions.

\subsection{NORMAL DUTY HOURS}


Normal duty hours for the Dryden Flight Research Center are from 7:30 am to 4:00 pm, Monday through Friday excluding holidays. The Contractor shall work during normal duty hours or outside normal duty hours as described in Section 01000 "SUMMARY OF WORK" Paragraph 1.6 "WORK HOURS". Requests to work outside the specified work hours shall require written approval from the Contracting Officer fourteen (14) days in advance of the proposed work period.

\subsection{SPACE SHUTTLE MISSION}

During Space Shuttle Mission landing dates at NASA/DFRC, Contract work on the site shall be restricted. During Space Shuttle Mission turn-around at NASA/DFRC, the Contractor may resume work, except for work on utilities which supply the Shuttle Area (Area 'A') or on utilities which are related to Space Shuttle activities.

In the event of an occasional shuttle landing at Edwards/DFRC the Contractor shall be required to suspend on-site construction work for the period of the shuttle turnaround (usually about 5 days). Primary landing site for most shuttle missions is Cape Canaveral, Florida, but Edwards/DFRC is always a stand-by secondary landing site. The Contractor shall be given at least 3 days advance notice of possible landing dates; and only about 3 hours notice of actual landing notification.

Space Shuttle landing schedules are subject to change and information can be obtained from the Contracting Officer. Upon written request to the Contracting Officer, the Contractor will receive time extensions for all Space Shuttle Landing delays.

\section{$\underline{1.10 \text { PROJECT MEETINGS }}$}

\subsubsection{Preconstruction Conference}

The Contractor shall attend a preconstruction conference scheduled by the Contracting Officer. Work shall not commence prior to the conference. Discussion shall address project orientation, personnel contact, safety issues, permits, deficiencies, and the location of the Contractor's office. Contractor shall provide at the meeting a safety plan that follows the outline of specification section 01411 - General Safety Requirements, specific to NASA Dryden.

\subsubsection{Weekly Project Meetings}

The Contractor shall attend weekly project meetings scheduled by the Government. Discussion shall address safety issues, quality control, submittals, progress schedule, schedule of submittals, as-built drawings, deficiencies, material delivery, permits, equipment delivery, invoices, potential factors of delay, request for information (RFIs), changes, and functional tests.

\subsection{OCCUPANCY OF PREMISES}


The buildings will be occupied during performance of work under this Contract. Before work is started, the Contractor shall arrange with the Contracting Officer a sequence of procedure, means of access, space for storage of materials and equipment, and use of approaches, corridors, and stairways. Government personnel will be allowed in the construction area to perform routine or emergency maintenance on building systems and equipment. This includes communication, electrical, mechanical, and fire protection systems.

\section{$\underline{1.12 \text { TEMPORARY UTILITIES }}$}

Contractor shall provide temporary utilities required for construction. Materials may be new or used, shall be adequate for the required usage, shall not create unsafe conditions, and shall not violate applicable codes and standards.

\subsubsection{Electricity}

Contractor will have access to electrical power in the generator building.

\subsubsection{Water}

Contractor shall make connections to existing facilities to provide water for construction purposes. Water used will be furnished by the Government.

\subsubsection{Telephone Service}

The Contractor shall provide telephone service for Contractor use. The Contractor shall pay costs of service. The Contractor shall coordinate with the Contracting Officer and NASA/DFRC telecommunications, at (661) 258-6100, to allow system coordination for emergency 911 services.

\subsubsection{Sanitary Facilities}

The Contractor shall provide temporary sanitary facilities and shall service, clean, and maintain these facilities and enclosures. Temporary facilities shall be removed from the site at the completion of the work.

\subsection{TEMPORARY STRUCTURES}

Contractor-owned or leased trailers and temporary structures, where telephone service is installed and connected to 911 emergency system, shall be identified by Government assigned numbers. The required building number shall be furnished by the Government. The required building number shall be displayed on the structure on signs having brilliant blue background, white numbers, and of dimensions 18 inches by 36 inches. The signs shall be displayed on two sides of the structure at the upper left corner. The Contractor shall apply the number to the trailers within 14 days of placement, or sooner, if directed by the Government. 


\section{$\underline{1.14 \text { TRAFFIC PROVISIONS }}$}

The Contractor shall conduct operations in a manner that will not close any thoroughfare, or interfere in any way with traffic on railways or highways, except with written permission of the Contracting Officer. Contractor shall provide, erect, and maintain, at his own expense, lights, barriers, signals, passageways, detours, signs, and other traffic devices that may be required. Other than the above restrictions, the Contractor may move oversized and/or slow moving vehicles to the worksite provided all requirements of the State Highway Department have been met.

\subsection{CONFORMANCE TO REFERENCED SPECIFICATIONS}

Wherever in the various Sections of these specifications, material or equipment to be furnished or work to be done is required to conform to Federal Specifications, IEEE, NEC, NESC, ASTM, AISC, ACI, SAE, or any other generally recognized authority, the latest revised edition of such specification in effect on the date of the solicitation shall apply.

\subsection{MATERIAL AND EQUIPMENT}

Shipments shall be addressed to the Contractor who shall be responsible for their receipt, unloading, handling, and storage at the site. The Government will not accept deliveries on behalf of the Contractor or Subcontractors or assume responsibility for security of materials, equipment, or supplies delivered to the site. The Contractor shall not have any material or equipment deliveries made to the DFRC shipping and receiving warehouse. The Contractor shall use the following address:

[Name of Contractor's firm or company]

P.O.C. [Name of Contractor's superintendent or other employee]

[Project title]

Dryden Flight Research Center

Edwards, CA 93524

The Contractor shall protect and preserve materials, supplies, and equipment of every description, including property that may be Government-furnished or Government-owned. Material to be salvaged and reinstalled by the Contractor shall be protected during removal and stored to prevent damage. Only material and construction equipment designated for performance of contract work may be stored at the construction site or located in Government-controlled areas.

Materials and equipment to be provided under this contract shall be standard catalogue products of manufacturers regularly engaged in the manufacture of the products. Material and equipment shall be installed in accordance with the requirements of the contract drawings and approved recommendations of the manufacturers.

\subsection{SALVAGE MATERIALS AND EQUIPMENT}


All items of materials designated by the Contracting Officer to be salvaged shall remain the property of the Government. Salvage items shall be marked, segregated, itemized, delivered, and off-loaded by the Contractor at the storage area near Building 4876 .

The Contractor shall maintain adequate property control records for all materials or equipment designated as salvage. These records may be in accordance with the Contractor's system of property control, if approved by the Contracting Officer. The Contractor shall be responsible for adequate storage and protection of salvaged materials and equipment and shall replace, at no cost to the Government, salvage materials and equipment broken or damaged during salvage operations.

\subsection{STARTING OF SYSTEMS}

The Contractor shall perform formal functional tests with full documentation using the approved recording form. Test procedures and recording form that document the test steps shall be submitted for approval to the Contracting Officer twenty one (21) calendar days prior to the proposed test date. The procedure shall consist of step by step instruction to verify system parameters, components, and functions.

The Contractor shall perform an "in-house" test to verify that the system and components have been properly installed and are functioning properly. Test shall be performed in the presence of the Contracting Officer. Test shall be completed and found acceptable when one full test has been performed without component or system malfunction. The contractor shall submit a Functional Test Report documenting the actual steps and results of the test.

\subsection{GOVERNMENT INSPECTION}

Government in-process and end-item inspections will be performed at the construction site and at the Contractor's or subcontractor's facility by a designated Government representative to assure compliance with the contract requirements, drawings, and technical specifications. The extent of such inspection will depend upon the level of quality and workmanship of the items. The Contractor shall notify the Contracting Officer of scheduled inspections a minimum of 48 hours prior to such scheduled inspections.

The Contractor shall give 24-hour advance notice to the Contracting Officer of the date when the contract work will begin at the site to allow coordination with the inspection staff. Should the Contractor unexpectedly suspend work at any time prior to completion of the contract, the Contractor shall notify the Contracting Officer as soon as possible. If work is suspended for 3 days or longer, the Contractor shall not resume work without notifying the Contracting Officer 24-hours in advance. (See also Section entitled "QUALITY CONTROL", Paragraph entitled "Government Inspections and Tests".)

\subsection{OPERATION AND MAINTENANCE DATA}

Submit five copies of the manufacturers' operation and maintenance (O\&M) data for the components, assemblies, subassemblies, attachments, and accessories specified herein. Submit 
O\&M data which is specifically applicable to this contract and a complete and concise depiction of the provided equipment or product. Present information in sufficient detail to clearly explain user O\&M requirements at the system, equipment, component, and subassembly level. Submit data specified for a given item within 30 calendar days prior to testing the system involved. List personnel hazards and equipment or product safety precautions for all operating conditions. Submit in accordance with section entitled "SUBMITTALS".

Preventive Maintenance and Inspection Instructions shall be submitted by the Contractor with schedules that state when systems should be retested. Included shall be procedures for preventive maintenance, inspection, adjustment, lubrication and cleaning necessary to minimize corrective maintenance and repairs. The instructions shall inform operators how to check out, troubleshoot, repair, and replace components of the system. Instructions shall include electrical and mechanical schematics and diagrams and diagnostic techniques necessary to enable operation and troubleshooting of the system after acceptance.

Posted Instructions shall be submitted by the Contractor with labels, signs, and templates of operating instructions that are required to be mounted near the product for normal safe operations. Include a control sequence for each of these following operations: startup, shutdown, and post shutdown. Include a list of environmental conditions (temperature, humidity, and other relevant data) which are best suited for each product or piece of equipment and describe conditions under which equipment should not be allowed to run. Include lubrication data.

Operation and Maintenance Manuals shall be submitted by the Contractor and shall be consistent with the manufacturer's standard brochures, schematics, printed instructions, general operating procedures, and safety precautions. Information shall be bound in manual format and grouped by technical sections. Caution and warning indications shall be clearly labeled.

\subsection{AS-BUILT DRAWINGS}

\subsubsection{Red-Marked Prints}

The Contractor shall maintain at the jobsite one set of full-size contract drawings, marked in red to show any deviations which have been made from the contract drawings, including buried or concealed construction and utility features revealed during the course of construction. Record the horizontal and vertical location of all buried utilities that differ from the contract drawings.

These red-marked drawings shall be available for review by the Contracting Officer's Technical Representative at all times. Upon completion of the work, deliver the red-marked sets of prints to the Contracting Officer. Requests for partial payments will not be approved if the red-marked drawings are not current.

\subsubsection{Electronic As-Builts (AutoCAD)}

Request for final payment will not be approved until the completed As-Built Drawings are delivered to the Contracting Officer and approved. The Contractor shall deliver to the Contracting Officer completed As-Built drawings in electronic format; AutoCAD 2002 with all 
entities in model space and all external references bound to each drawing. Each drawing shall be autonomous with all blocks, macros, functions and entities.

\subsection{WARRANTY OF CONSTRUCTION}

In addition to any other warranties in this contract, the Contractor warrants that work performed under this contract conforms to the contract requirements and is free of any defect in equipment, material, or design furnished, or workmanship performed by the Contractor or any subcontractor or supplier at any tier. This warranty shall continue for a period of one year from the date of final acceptance of the work. If the Government takes possession of any part of the work before final acceptance, this warranty shall continue for a period of one year from the date the Government takes possession.

PART 2 PRODUCTS (Not Applicable)

PART 3 EXECUTION (Not Applicable)

END OF SECTION 01010 
$\underline{\text { SECTION 01330-SUBMITTAL PROCEDURES 05/04 }}$

\section{$\underline{\text { PART } 1 \text { GENERAL }}$}

\subsection{SUMMARY}

Requirements of this Section apply to, and are a component part of, each section of the specifications.

\subsection{REFERENCES}

Not Used

\subsection{SUBMITTALS}

A standard transmittal form provided by the Government shall be used to transmit each submittal.

Submittal Description (SD): Drawings, diagrams, layouts, schematics, descriptive literature, illustrations, schedules, performance and test data, and similar materials to be furnished by the Contractor explaining in detail specific portions of the work required by the contract.

The following items, SD-01 through SD-11, are descriptions of data to be submitted for the project. The requirements to actually furnish the applicable items will be called out in each specification.

However, as a minimum, provide test reports, installation, operation and maintenance submittals and manuals as original data bound in three ring binders. Equipment actually installed will be clearly marked.

Provide only those submittals considered critical to assure quality and compliance to the contract as "approval" processing and are indicated with a "G." All other submittals include are for record only.

\section{SD-01 Preconstruction Submittals}

Submittals which are required prior to a notice to proceed on a new contract. Submittals required prior to the start of the next major phase of the construction on a multi-phase contract. Schedules or tabular list of data or tabular list including location, features, or other pertinent information regarding products, materials, equipment, or components to be used in the work, submitted prior to contract notice to proceed or next major phase of construction.

\section{SD-02 Shop Drawings}


Submittals which graphically show relationship of various components of the work, schematic diagrams of systems, detail of fabrications, layout of particular elements, connections, and other relational aspects of the work.

\section{SD-03 Product Data}

Data composed of catalog cuts, brochures, circulars, specifications and product data, and printed information in sufficient detail and scope to verify compliance with requirements of the contract documents.

\section{SD-04 Samples}

Samples, including both fabricated and unfabricated physical examples of materials, products, and units of work as complete units or as portions of units of work.

SD-05 Design Data

Design calculations, mix design analyses, or other data, written in nature, and pertaining to a part of the work.

\section{SD-06 Test Reports}

Written reports of a manufacturer's findings of his product during field inspections, attesting that the products are installed in accordance with the manufacturer's installation instructions, shop drawings, or other manufacturer's requirements. Written reports by a general contractor or his subcontractors including daily logs reporting on the progress of daily activities or attesting that the work has been installed in accordance with the contract plans and specifications.

\section{SD-07 Certificates}

A document, required of the Contractor, or through the Contractor by way of a supplier, installer, manufacturer, or other Lower Tier Contractor, the purpose of which is to further the quality or orderly progression of a portion of the work by documenting procedures, acceptability of methods or personnel, qualifications, or other verification of quality.

Statements signed by responsible officials of a manufacturer of a product, system, or material attesting that the product, system or material meet specified requirements. Statements must be dated after the award of this contract, name the project, and list the specific requirements which it is intended to address.

\section{SD-08 Manufacturer's Instructions}

Preprinted material describing installation of a product, system, or material, including special notices and material safety data sheets, if any concerning impedances, hazards, and safety precautions. 
SD-09 Manufacturer's Field Reports

A written report which includes the findings of a test made at the job site, in the vicinity of the job site, or on a sample taken from the job site, on a portion of the work, during or after installation. Report must be signed by an authorized official of a testing laboratory or agency and must state the test results; and indicate whether the material, product, or system has passed or failed the test.

SD-10 Operation and Maintenance Data

Data intended to be incorporated in an operations and maintenance manual.

\section{SD-11 Closeout Submittals}

Special requirements necessary to properly close out a construction contract. For example, as-built record drawings, manufacturer's help and product lines necessary to maintain and install equipment. Also, submittal requirements necessary to properly close out a major phase of construction on a multi-phase contract.

\subsection{PREPARATION}

\subsubsection{Marking}

Prepare, review and stamp with Contractor's approval all specified submittals.

Permanently mark each submittal to identify it by contract number; transmittal date; Contractor's, Subcontractor's, and supplier's name, address(es) and telephone number(s); submittal name; specification or drawing reference; and similar information to distinguish it from other submittals. Submittal identification shall include space to receive the review action by the Contracting Officer.

\subsubsection{Drawing Format}

Drawing submittals shall be prepared on translucent, reproducible sheets, not less than $8-1 / 2$ by 11 inches nor larger than 30 by 42 inches in size, except for full size patterns or templates.

Drawings shall be prepared to accurate size, with scale indicated, unless other form is required. Drawing reproducibles shall be suitable for microfilming and reproduction on the Diazo or Ozalid machines and shall be of a quality to produce clear, distinct lines and letters. Drawings shall have dark lines on a white background.

Copies of each drawing sheet shall have the following information clearly marked thereon:

a. Job name, which shall be the general title of the contract drawings.

b. Date of the drawings and revisions. 
c. Name of Contractor.

d. Name of Subcontractor.

e. Name of the item, material, or equipment detailed thereon.

f. Submittal number (e.g., first submittal to last submittal) in a uniform location adjacent to the title block.

g. Specification section to which submittal applies.

h. Government contract number shall appear in the margin, immediately below the title block.

Drawings shall be numbered in logical sequence. Contractor may use his own number system. Each drawing shall bear the number of the submittal in a uniform location adjacent to the title block. Government contract number shall appear in the margin, immediately below the title block, for each drawing.

A blank space, no smaller than 3 inches shall be reserved on the right hand side of each sheet for the Government disposition stamp.

\subsubsection{Data Format}

Required data submittals for each specific material, product, unit of work, or system shall be collected into a single submittal and marked for choices, options, and portions applicable to the submittal. Marking of each copy of product data submitted shall be identical. Partial submittals will be accepted for expedition of construction effort.

\subsubsection{Samples}

Samples shall be physically identical with the proposed material or product to be incorporated in the work, fully fabricated and finished in the specified manner, and full scale. Where variations in color, finish, pattern, or texture are inherent in the material or product represented by the sample, multiple units of the sample, showing the near-limits of the variations and the "average" of the whole range (not less than 3 units), shall be submitted. Each unit shall be marked to describe its relation to the range of the variation. Where samples are specified for selection of color, finish, pattern, or texture, the full set of available choices shall be submitted for the material or product specified. Sizes and quantities of samples shall represent their respective standard unit.

\subsection{SUBMISSION REQUIREMENTS}

\subsubsection{Schedules}


Within 15 calendar days of notice to proceed, provide, for approval by the Contracting Officer, the following schedule of submittals:

a. A schedule of shop drawings and technical submittals required by the specifications and drawings. Indicate the specification or drawing reference requiring the submittal; the material, item, or process for which the submittal is required; the "SD" number and identifying title of the submittal; the Contractor's anticipated submission date and the approval need date.

b. A separate schedule of other submittals required under the contract but not listed in the specifications or drawings. Schedule will indicate the contract requirement reference; the type or title of the submittal; the Contractor's anticipated submission date and the approved need date (if approval is required).

c. Submittals called for by the contract documents will be listed on one of the above schedules. If a submittal is called for but does not pertain to the contract work, the Contractor shall include the submittal in the applicable schedule and annotate it "N/A" with a brief explanation. Approval of the schedules by the Contracting Officer does not relieve the Contractor of supplying submittals required by the contract documents but which have been omitted from the schedules or marked "N/A".

d. Re-submit copies of both schedules and annotate monthly by the Contractor with actual submission and approval dates. When all items on a schedule have been fully approved, no further re-submittal of the schedule is required.

\subsubsection{Drawings Submittals}

Submit one translucent reproducible copy(s) and five blackline or blueline opaque print(s) of each drawing. Two prints, marked with review notations by the Contracting Officer, will be returned to the Contractor. All required installation, fabrication and connection drawings shall be submitted and approved prior to the start of work detailed on these drawings.

\subsubsection{Data Submittals}

Submit six complete sets of indexed and bound product data. Two sets, marked with review notations by the Contracting Officer, will be returned to the Contractor.

\subsubsection{Samples}

Submit one set of identified samples. A copy of the transmittal form, marked with review notations including selections by the Contracting Officer, will be returned to the Contractor.

Samples that are intended or permitted to be returned and actually incorporated in the work are so indicated in the individual technical sections. These samples will be returned to the Contractor, at his expense, to be clearly labeled, with installation location recorded. Samples shall be in undamaged condition at the time of installation. 
Where mockups and similar large samples are required by individual technical sections, it is recognized that these are a special type of sample which cannot be readily "transmitted" as specified for submittal of samples. Otherwise, and except as indicated in the individual technical sections, the requirements for samples shall be complied with and a transmittal form shall be processed for each mockup, to provide a record of the activity.

\subsection{GOVERNMENT'S REVIEW}

\subsubsection{Review Notations}

Contracting Officer will review submittals and provide pertinent notation within 15 calendar days after date of submission. Submittals will be returned to the Contractor with the following notations:

a. Submittals marked "approved" authorize the Contractor to proceed with the work covered.

b. Submittals marked "approved as noted" authorize the Contractor to proceed with the work covered provided he takes no exception to the corrections. Notes shall be incorporated prior to submission of the final submittal.

c. Submittals marked "return for correction" require the Contractor to make the necessary corrections and revisions and to re-submit them for approval in the same routine as before, prior to proceeding with any of the work depicted by the submittal.

d. Submittals marked "not approved" or "disapproved" indicate noncompliance with the contract requirements and shall be re-submitted with appropriate changes. No item of requiring a submittal shall be accomplished until the submittals are approved or approved as noted.

e. Contractor shall make corrections required by the Contracting Officer. If the Contractor considers any correction or notation on the returned submittals to constitute a change to the contract drawings or specifications; notice as required under the clause entitled, "Changes" shall be given to the Contracting Officer. Approval of the submittals by the Contracting Officer shall not be construed as a complete check, but will indicate only that the general method of construction and detailing is satisfactory. Contractor shall be responsible for the dimensions and design of connection details and construction of work. Failure to point out deviations may result in the Government requiring rejection and removal of such work at the Contractor's expense.

f. If changes are necessary to approved submittals, the Contractor shall make such revisions and submission of the submittals in accordance with the procedures above. No item of work requiring a submittal change shall be accomplished until the changed submittals are approved.

\subsubsection{Sample Approval}


Furnish, for the approval of the Contracting Officer, samples required by the specifications or by the Contracting Officer. Shipping charges shall be paid by the Contractor. Materials or equipment requiring sample approval shall not be delivered to the site or used in the work until approved in writing by the Contracting Officer.

Each sample shall have a label indicating:

a. Name of project

b. Name of Contractor

c. Material or equipment

d. Place of origin

e. Name of producer and brand

f. Specification section to which samples applies

g. Samples of furnished material shall have additional markings that will identify them under the finished schedules.

Contractor shall submit to the Contracting Officer two samples of materials where samples are requested. Transmit to the Contracting Officer with each sample a letter, original and two copies, containing the above information.

Approval of a sample shall be only for the characteristics or use named in such approval and shall not be construed to change or modify any contract requirements. Before submitting samples, the Contractor shall assure that the materials or equipment will be available in quantities required in the project. No change or substitution will be permitted after a sample has been approved.

Materials and equipment incorporated in the work shall match the approved samples. If requested, approved samples, including those which may be damaged in testing, will be returned to the Contractor, at his expense, upon completion of the contract. Samples not approved will also be returned to the Contractor at its expense, if so requested.

Failure of any materials to pass the specified tests will be sufficient cause for refusal to consider, under this contract, any further samples of the same brand or make of that material. Government reserves the right to disapproved any material or equipment which previously has proved unsatisfactory in service.

Variations from contract requirements shall be specifically pointed out in transmittal letters. Failure to point out deviations may result in the Government requiring rejection and removal of such work at no additional cost to the Government. 
Samples of various materials or equipment delivered on the site or in place may be taken by the Contracting Officer for testing. Samples failing to meet contract requirements will automatically void previous approvals. Contractor shall replace such materials or equipment to meet contract requirements.

Approval of the Contractor's samples by the Contracting Officer shall not relieve the Contractor of his responsibilities under the contract.

\subsection{PROGRESS SCHEDULE}

\subsubsection{Bar Chart}

a. Submit the progress chart, for approval by the Contracting Officer, at the Preconstruction Conference in one reproducible and 4 copies.

b. Prepare the progress chart in the form of a bar chart utilizing form "Construction Progress Chart" or comparable format acceptable to the Contracting Officer.

c. Include no less than the following information on the progress chart:

(1) Break out by major headings for primary work activity.

(2) A line item break out under each major heading sufficient to track the progress of the work.

(3) A line item showing contract finalization task which includes punch list, clean-up and demolition, and final construction drawings.

(4) A materials bar and a separate labor bar for each line item. Both bars will show the scheduled percentage complete for any given date within the contract performance period. Labor bar will also show the number of men (man-load) expected to be working on any given date within the contract performance period.

(5) The estimated cost and percentage weight of total contract cost for each materials and labor bar on the chart.

(6) Separate line items for mobilization and drawing submittal and approval. (These items are to show no associated costs.)

d. Update the progress schedule in one reproduction and 4 copies every 30 calendar days throughout the contract performance period.

\subsubsection{Project Network Analysis}


Submit the initial progress schedule within 21 calendar days of notice to proceed. Schedule shall be updated and resubmitted monthly beginning 7 calendar days after return of the approved initial schedule. Updating shall entail complete revision of the graphic and data displays incorporating changes in scheduled dates and performance periods. Redlined updates will only be acceptable for use as weekly status reviews.

Contractor shall provide a single point contact from his on-site organization as his Schedule Specialist. Schedule Specialist shall have the responsibility of updating and coordinating the schedule with actual job conditions. Schedule Specialist shall participate in weekly status meetings and present current information on the status of purchase orders, shop drawings, offsite fabrication, materials deliveries, Subcontractor activities, anticipated needs for Government furnished equipment, and any problem which may impact the contract performance period.

Include the following in the project network analysis:

a. Graphic display shall be a standard network or arrow diagram capable of illustrating the required data. Drafting shall be computer generated on standard 24 by 36 inch (nominal size) drafting sheets or on small (11 by 17 inch minimum) sheets with separate overview and detail breakouts. Provide a project network analysis that is legible with a clear, consistent method for continuations and detail referencing. Clearly delineate the critical path on the display. Clearly indicate the contract milestone date on the project network analysis graphic display.

b. Data shall be presented as a separate printout on paper or, where feasible, may be printed on the same sheet as the graphic display. Data shall be organized in a logical coherent display capable of periodic updating.

c. Data shall include verbal activity descriptions with a numerical ordering system cross referenced to the graphic display. Additionally, costs (broken down into separate materials and labor costs), duration, early start date, early finish date, late start date, late finish date, and float shall be detailed for each activity. A running total of the percent completion based on completed activity costs versus total contract cost shall be indicated. A system for indicating scheduled versus actual activity dates and durations shall be provided.

d. Schedule shall be of sufficient detail to facilitate the Contractor's control of the job and to allow the Contracting Officer to readily follow progress for portions of the work.

\subsection{STATUS REPORT ON MATERIALS ORDERS}

Within 15 calendar days after notice to proceed, submit, for approval by the Contracting Officer, an initial material status report on all materials orders. This report will be updated and resubmitted every 30 calendar days as the status on material orders changes.

Report shall list, in chronological order by need date, materials orders necessary for completion of the contract. The following information will be required for each material order listed: 
a. Material name, supplier, and invoice number.

b. Bar chart line item or CPM activity number affected by the order.

c. Delivery date needed to allow directly and indirectly related work to be completed within the contract performance period.

d. Current delivery date agreed on by supplier.

e. When item $d$ exceeds item $c$, the effect that delayed delivery date will have on contract completion date.

f. When item $d$ exceeds item c, a summary of efforts made by the Contractor to expedite the delayed delivery date to bring it in line with the needed delivery date, including efforts made to place the order (or subcontract) with other suppliers.

PART 2 PRODUCTS (Not Applicable)

PART 2 EXECUTION (Not Applicable)

END OF SECTION 01330 
$\underline{\text { SECTION 01401D - CONTRACTOR QUALITY CONTROL }}$

\section{PART 1 - GENERAL}

\subsection{REFERENCES}

The publications listed below form a part of this specification to the extent referenced. The publications are referred to within the text by basic designation only.

\section{AMERICAN SOCIETY FOR TESTING AND MATERIALS (ASTM)}

ASTM A 880

ASTM C 1077

ASTM D 3666

ASTM D 3740

ASTM E 329

ASTM E 543
(1995) Criteria for Use in Evaluation of Testing Laboratories and Organizations for Examination and Inspection of Steel, Stainless Steel, and Related Alloys

(2003a) Laboratories Testing Concrete and Concrete Aggregates for Use in Construction and Criteria for Laboratory Evaluation

(2003) Minimum Requirements for Agencies Testing and Inspecting Road and Paving Materials

(2001) Minimum Requirements for Agencies Engaged in the Testing and/or Inspection of Soil and Rock as Used in Engineering Design and Construction (2003) Agencies Engaged in the Testing and/or Inspection of Materials Used in Construction (2002) Agencies Performing Nondestructive Testing

\section{U.S. ARMY CORPS OF ENGINEERS (USACE)}

EM 385-1-1

(2003) Safety and Health Requirements Manual

\subsection{PAYMENT}

Separate payment will not be made for providing and maintaining an effective Quality Control program, and all costs associated therewith shall be included in the applicable unit prices or lump-sum prices contained in the Bid Schedule or Cost Proposal.

\subsection{SUBMITTALS}

Government approval is required for submittals with a "G" designation; submittals not having a "G" designation are for information only or as otherwise designated. The following shall be submitted in accordance with Section 01330 SUBMITTAL PROCEDURES: 
SD-01 Preconstruction Submittals

Construction Quality Control (CQC) Plan; G

Submit a CQC plan within $[\mathbf{1 5}$ ] calendar days after receipt of Notice To Proceed.

\section{PART 2 PRODUCTS (Not Applicable)}

\section{PART 3 EXECUTION}

\subsection{GENERAL REQUIREMENTS}

The Contractor is responsible for quality control and shall establish and maintain an effective quality control system in compliance with the Contract Clause titled "Inspection of Construction." The quality control system shall consist of plans, procedures, and organization necessary to produce an end product which complies with the contract requirements. The system shall cover all construction operations, both onsite and offsite, and shall be keyed to the proposed construction sequence. The site project superintendent will be held responsible for the quality of work on the job and is subject to removal by the Contracting Officer for noncompliance with the quality requirements specified in the contract. The site project superintendent in this context shall be the highest level manager responsible for the overall construction activities at the site, including quality and production. The site project superintendent shall maintain a physical presence at the site at all times, except as otherwise acceptable to the Contracting Officer, and shall be responsible for all construction and construction related activities at the site.

\subsection{QUALITY CONTROL PLAN}

The Contractor shall furnish for review by the Government, not later than $[15]$ calendar days after receipt of Notice to Proceed, the Contractor Quality Control (CQC) Plan proposed to implement the requirements of the Contract Clause titled "Inspection of Construction." The plan shall identify personnel, procedures, control, instructions, tests, records, and forms to be used. Construction will be permitted to begin only after acceptance of the CQC Plan [or acceptance of an interim plan applicable to the particular feature of work to be started. Work outside of the features of work included in an accepted interim plan will not be permitted to begin until acceptance of a CQC Plan or another interim plan containing the additional features of work to be started].

\subsubsection{Construction Quality Control (CQC) Plan}

Provide, for acceptance by the Contracting Officer, a Construction QC plan submitted in a 3-ring binder with pages numbered sequentially that covers both on-site and off-site work and includes the following: 
a. A table of contents listing the major sections identified with tabs in the following order:

I. QC ORGANIZATION

II. NAMES AND QUALIFICATIONS

III. DUTIES, RESPONSIBILITY AND AUTHORITY OF QC PERSONNEL

IV. OUTSIDE ORGANIZATIONS

V. APPOINTMENT LETTERS

VI. SUBMITTAL PROCEDURES AND INITIAL SUBMITTAL REGISTER

VII. TESTING LABORATORY INFORMATION

VIII. TESTING PLAN AND LOG

IX. PROCEDURES TO COMPLETE REWORK ITEMS

$\mathrm{X}$. DOCUMENTATION PROCEDURES

XI. LIST OF DEFINABLE FEATURES

XII. PROCEDURES FOR PERFORMING THE THREE PHASES OF CONTROL

XIII. PERSONNEL MATRIX

b. A chart showing the QC organizational structure.

c. Names and qualifications, in resume format, for each person in the QC organization. Include the CQM for Construction course certifications for the QC Manager and Alternate QC Manager as required by the paragraphs entitled "Construction Quality Management Training" and "Alternate QC Manager Duties and Qualifications".

d. Duties, responsibilities and authorities of each person in the QC organization.

e. A listing of outside organizations such as, architectural and consulting engineering firms that will be employed by the Contractor and a description of the services these firms will provide.

f. Letters signed by an officer of the firm appointing the QC Manager and Alternate QC Manager and stating that they are responsible for implementing and managing the QC program as described in this contract. Include in this letter the responsibility of the QC Manager and Alternate QC Manager to implement and manage the three phases of quality control, and their authority to stop work which is not in compliance with the contract. The QC Manager shall issue letters of direction to [the Assistant QC Manager and] all other QC specialists outlining their duties, authorities, and responsibilities. Copies of the letters shall be included in the QC plan.

g. Procedures for reviewing, approving and managing submittals. Provide the name(s) of the person(s) in the QC organization authorized to review and certify submittals prior to approval. Provide the initial submittal of the Submittal Register as specified in section entitled "Submittal Procedures." 
h. Testing laboratory information required by the paragraphs entitled "Accreditation Requirements" or "Construction Materials Testing Laboratory Requirements", as applicable.

i. A Testing Plan and Log that includes the tests required, referenced by the specification paragraph number requiring the test, the frequency, and the person responsible for each test.

j. Procedures to identify, record, track and complete rework items.

k. Documentation procedures, including proposed report formats.

1. List of definable features of work. A definable feature of work (DFOW) is a task, which is separate and distinct from other tasks, has the same control requirements and work crews. The list shall be cross-referenced to the contractor's Construction Schedule and the specification sections. The DFOW list shall include, as a minimum, all items of work on the progress schedule or all critical path activities.

m. Procedures for Performing the Three Phases of Control. For each DFOW, provide the DFOW's Preparatory and Initial Phase Checklists. Each list shall include a breakdown of quality checks that will be used when performing the quality control functions, inspections, and tests required by the contract documents. The Preparatory and Initial Phases and meetings shall be conducted with a view towards obtaining quality construction by planning ahead and identifying potential problems for each definable feature of work.

n. A personnel matrix showing for each section of the specification who will review and approve submittals, who will perform and document the three phases of control, and who will perform and document the testing.]

\subsubsection{Acceptance of Plan}

Acceptance of the Contractor's plan is required prior to the start of construction. Acceptance is conditional and will be predicated on satisfactory performance during the construction. The Government reserves the right to require the Contractor to make changes in his CQC Plan and operations including removal of personnel, as necessary, to obtain the quality specified.

\subsubsection{Notification of Changes}

After acceptance of the CQC Plan, the Contractor shall notify the Contracting Officer in writing of any proposed change. Proposed changes are subject to acceptance by the Contracting Officer.

\section{$\underline{3.3}$ COORDINATION MEETING}

After the Preconstruction Conference, before start of construction, and prior to acceptance by the Government of the CQC Plan, the Contractor shall meet with the Contracting Officer or 
Authorized Representative and discuss the Contractor's quality control system. The CQC Plan shall be submitted for review a minimum of $\left[7 \_\right.$calendar days prior to the Coordination Meeting. During the meeting, a mutual understanding of the system details shall be developed, including the forms for recording the CQC operations, control activities, testing, administration of the system for both onsite and offsite work, and the interrelationship of Contractor's Management and control with the Government's Quality Assurance. Minutes of the meeting shall be prepared by the Government and signed by both the Contractor and the Contracting Officer. The minutes shall become a part of the contract file. There may be occasions when subsequent conferences will be called by either party to reconfirm mutual understandings and/or address deficiencies in the CQC system or procedures which may require corrective action by the Contractor.

\subsection{QUALITY CONTROL ORGANIZATION}

\subsubsection{Personnel Requirements}

The requirements for the CQC organization are a CQC Manager and sufficient number of additional qualified personnel to ensure safety and contract compliance. The Safety and Health Manager shall receive direction and authority from the CQC Manager and shall serve as a member of the CQC staff. All CQC personnel shall be familiar with the requirements of the EM 385-1-1. Personnel identified in the technical provisions as requiring specialized skills to assure the required work is being performed properly will also be included as part of the CQC organization. The Contractor's CQC staff shall maintain a presence at the site at all times during progress of the work and have complete authority and responsibility to take any action necessary to ensure contract compliance. The CQC staff shall be subject to acceptance by the Contracting Officer. The Contractor shall provide adequate office space, filing systems and other resources as necessary to maintain an effective and fully functional CQC organization. Complete records of all letters, material submittals, shop drawing submittals, schedules and all other project documentation shall be promptly furnished to the CQC organization by the Contractor. The CQC organization shall be responsible to maintain these documents and records at the site at all times, except as otherwise acceptable to the Contracting Officer.

\subsubsection{CQC Manager}

The Contractor shall identify as CQC Manager an individual within the onsite work organization who shall be responsible for overall management of CQC and have the authority to act in all CQC matters for the Contractor. The CQC Manager shall have a minimum of $[\mathbf{5}]$ years construction experience on construction similar to this contract. This CQC Manager shall be on the site at all times during construction and shall be employed by the prime Contractor. An alternate for the CQC Manager shall be identified in the plan to serve in the event of the Manager's absence. The requirements for the alternate shall be the same as for the designated CQC Manager.

\subsubsection{CQC Personnel}


In addition to CQC personnel specified elsewhere in the contract, the Contractor shall provide as part of the CQC organization specialized personnel to assist the CQC Manager for the following areas: mechanical (piping, HVAC, and controls). These individual(s) may be employees of the prime or subcontractor (unless otherwise specified); be responsible to the CQC Manager; be physically present at the construction site during work on their areas of responsibility; have the necessary education and/or experience in accordance with the experience matrix listed herein. These individuals may perform other duties but must be allowed sufficient time to perform their assigned quality control duties as described in the Quality Control Plan.

\section{Experience Matrix}

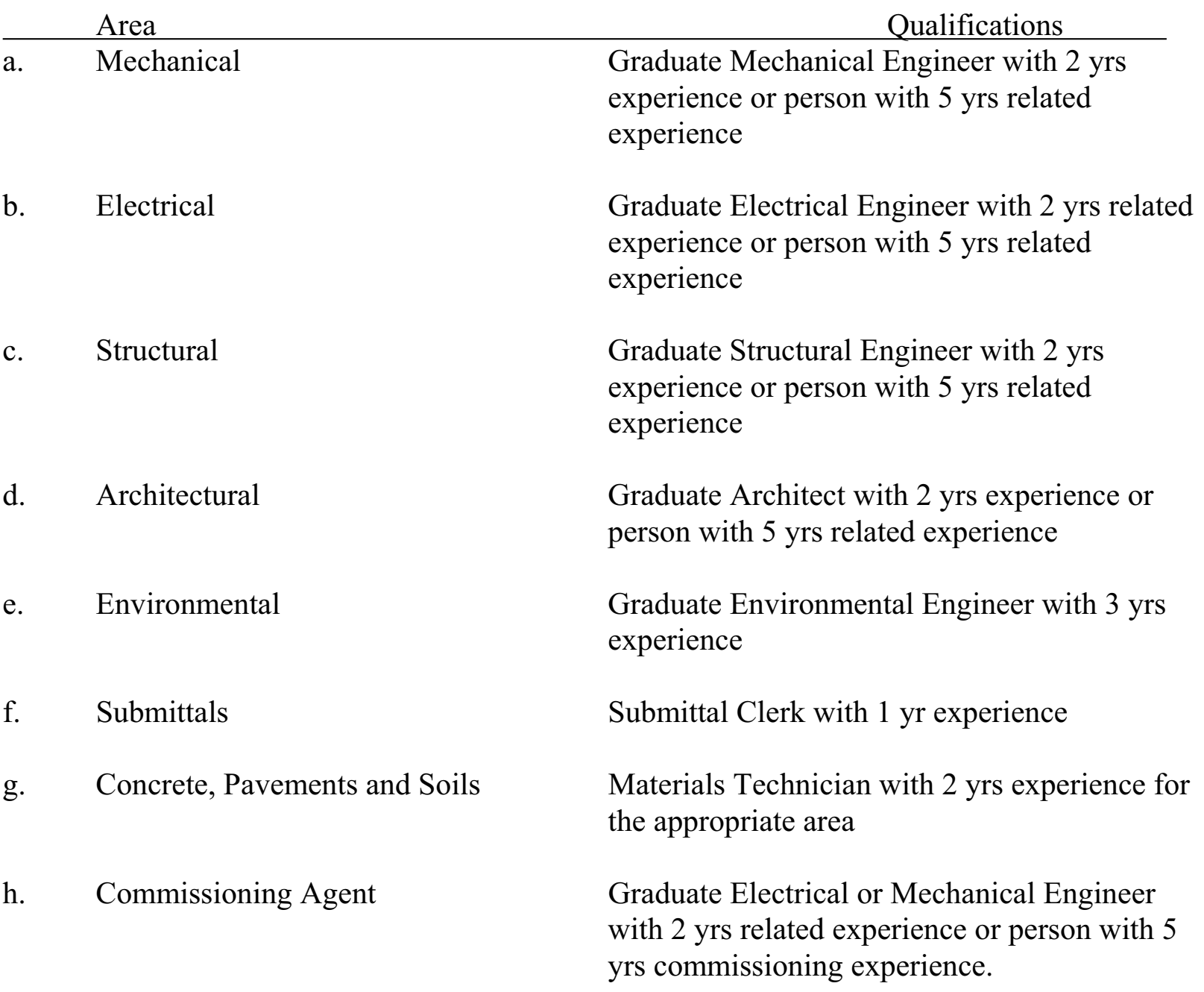

\subsubsection{Organizational Changes}

The Contractor shall maintain the CQC staff at full strength at all times. When it is necessary to make changes to the CQC staff, the Contractor shall revise the CQC Plan to reflect the changes and submit the changes to the Contracting Officer for acceptance.

\subsection{SUBMITTALS AND DELIVERABLES}


Submittals, if needed, shall be made as specified in Section 01330 SUBMITTAL PROCEDURES. The CQC organization shall be responsible for certifying that all submittals and deliverables are in compliance with the contract requirements. The CQC organization shall ensure adequate review time is allowed for each submittal.

\section{$\underline{3.6}$ CONTROL}

Contractor Quality Control is the means by which the Contractor ensures that the construction, to include that of subcontractors and suppliers, complies with the requirements of the contract. At least three phases of control shall be conducted by the CQC Manager for each definable feature of the construction work as follows:

\subsubsection{Preparatory Phase}

This phase shall be performed prior to beginning work on each definable feature of work, after all required plans/documents/materials are approved/accepted, and after copies are at the work site. This phase shall include:

a. A review of each paragraph of applicable specifications, reference codes, and standards. A copy of those sections of referenced codes and standards applicable to that portion of the work to be accomplished in the field shall be made available by the Contractor at the preparatory inspection. These copies shall be maintained in the field and available for use by Government personnel until final acceptance of the work.

b. A review of the contract drawings.

c. A check to assure that all materials and/or equipment have been tested, submitted, and approved.

d. Review of provisions that have been made to provide required control inspection and testing.

e. Examination of the work area to assure that all required preliminary work has been completed and is in compliance with the contract.

f. A physical examination of required materials, equipment, and sample work to assure that they are on hand, conform to approved shop drawings or submitted data, and are properly stored.

g. A review of the appropriate activity hazard analysis to assure safety requirements are met.

h. Discussion of procedures for controlling quality of the work including repetitive deficiencies. Document construction tolerances and workmanship standards for that feature of work. 
i. A check to ensure that the portion of the plan for the work to be performed has been accepted by the Contracting Officer.

j. Discussion of the initial control phase.

k. The Government shall be notified at least $\mathbf{2 4}]$ hours in advance of beginning the preparatory control phase. This phase shall include a meeting conducted by the CQC Manager and attended by the superintendent, other CQC personnel (as applicable), and the foreman responsible for the definable feature. The results of the preparatory phase actions shall be documented by separate minutes prepared by the CQC Manager and attached to the daily CQC report. The Contractor shall instruct applicable workers as to the acceptable level of workmanship required in order to meet contract specifications.

\subsubsection{Initial Phase}

This phase shall be accomplished at the beginning of a definable feature of work. The following shall be accomplished:

a. A check of work to ensure that it is in full compliance with contract requirements. Review minutes of the preparatory meeting.

b. Verify adequacy of controls to ensure full contract compliance. Verify required control inspection and testing.

c. Establish level of workmanship and verify that it meets minimum acceptable workmanship standards. Compare with required sample panels as appropriate.

d. Resolve all differences.

e. Check safety to include compliance with and upgrading of the safety plan and activity hazard analysis. Review the activity analysis with each worker.

f. The Government shall be notified at least $\mathbf{2 4}$ I hours in advance of beginning the initial phase. Separate minutes of this phase shall be prepared by the CQC Manager and attached to the daily CQC report. Exact location of initial phase shall be indicated for future reference and comparison with follow-up phases.

g. The initial phase should be repeated for each new crew to work onsite, or any time acceptable specified quality standards are not being met.

\subsubsection{Follow-up Phase}

Daily checks shall be performed to assure control activities, including control testing, are providing continued compliance with contract requirements, until completion of the particular feature of work. The checks shall be made a matter of record in the CQC documentation. Final 
follow-up checks shall be conducted and all deficiencies corrected prior to the start of additional features of work which may be affected by the deficient work. The Contractor shall not build upon nor conceal non-conforming work.

\subsubsection{Additional Preparatory and Initial Phases}

Additional preparatory and initial phases shall be conducted on the same definable features of work if: the quality of on-going work is unacceptable; if there are changes in the applicable CQC staff, onsite production supervision or work crew; if work on a definable feature is resumed after a substantial period of inactivity; or if other problems develop.

\section{$\underline{3.7 \quad \text { TESTS }}$}

\subsubsection{Testing Procedure}

The Contractor shall perform specified or required tests to verify that control measures are adequate to provide a product which conforms to contract requirements. Upon request, the Contractor shall furnish to the Government duplicate samples of test specimens for possible testing by the Government. Testing includes operation and/or acceptance tests when specified. The Contractor shall procure the services of an approved testing laboratory or establish an approved testing laboratory at the project site. The Contractor shall perform the following activities and record and provide the following data:

a. Verify that testing procedures comply with contract requirements.

b. Verify that facilities and testing equipment are available and comply with testing standards.

c. Check test instrument calibration data against certified standards.

d. Verify that recording forms and test identification control number system, including all of the test documentation requirements, have been prepared.

e. Results of all tests taken, both passing and failing tests, shall be recorded on the CQC report for the date taken. Specification paragraph reference, location where tests were taken, and the sequential control number identifying the test shall be given. If approved by the Contracting Officer, actual test reports may be submitted later with a reference to the test number and date taken. An information copy of tests performed by an offsite or commercial test facility shall be provided directly to the Contracting Officer. Failure to submit timely test reports as stated may result in nonpayment for related work performed and disapproval of the test facility for this contract.

\subsubsection{Testing Laboratories}

Except as stated otherwise in the specification sections, perform sampling and testing required under this Contract. 


\subsubsection{Accreditation Requirements}

Construction materials testing laboratories performing work on construction contracts will be required to submit the following:

a. A copy of the Certificate of Accreditation and Scope of Accreditation by an acceptable laboratory accreditation authority.

Construction materials testing laboratories performing work on construction contracts must be accredited by one of the laboratory accreditation authorities. The laboratory's scope of accreditation must include the ASTM standards listed in the paragraph titled "Construction Materials Testing Laboratory Requirements" as appropriate to the testing field. The policy applies to the specific laboratory performing the actual testing, not just the "Corporate Office".

\subsubsection{Construction Materials Testing Laboratory Requirements}

Provide an independent construction materials testing laboratory [or establish a laboratory] accredited by an acceptable laboratory accreditation authority to perform sampling and tests required by this Contract. Testing laboratories that have obtained accreditation by an acceptable laboratory accreditation authority listed in the paragraph entitled "Laboratory Accreditation Authorities" submit to the Contracting Officer, a copy of the Certificate of Accreditation and Scope of Accreditation. The scope of the laboratory's accreditation shall include the test methods required by the Contract. For testing laboratories that have not yet obtained accreditation by an acceptable laboratory accreditation authority listed in the paragraph entitled "Laboratory Accreditation Authorities" submit an acknowledgment letter from one of the laboratory accreditation authorities indicating that the application for accreditation has been received and the accreditation process has started, and submit to the Contracting Officer for approval, certified statements, signed by an official of the testing laboratory attesting that the proposed laboratory, meets or conforms to the ASTM standards listed below as appropriate to the testing field.

a. Laboratories engaged in testing of construction materials shall meet the requirements of ASTM E 329.

b. Laboratories engaged in testing of concrete and concrete aggregates shall meet the requirements of ASTM C 1077.

c. Laboratories engaged in testing of bituminous paving materials shall meet the requirements of ASTM D 3666.

d. Laboratories engaged in testing of soil and rock, as used in engineering design and construction, shall meet the requirements of ASTM D 3740.

e. Laboratories engaged in inspection and testing of steel, stainless steel, and related alloys will be evaluated according to ASTM A 880. 
f. Laboratories engaged in nondestructive testing (NDT) shall meet the requirements of ASTM E 543.

g. Laboratories engaged in Hazardous Materials Testing shall meet the requirements of OSHA and EPA.

\subsubsection{Laboratory Accreditation Authorities}

Laboratory Accreditation Authorities include the National Voluntary Laboratory Accreditation Program (NVLAP) administered by the National Institute of Standards and Technology, the American Association of State Highway and Transportation Officials (AASHTO) program, International Accreditation Services, Inc., U.S. Army Corps of Engineers Materials Testing Center (MTC), and the American Association for Laboratory Accreditation (A2LA) program.

Furnish to the Contracting Officer, a copy of the Certificate of Accreditation and Scope of Accreditation. The scope of the laboratory's accreditation shall include the test methods required by the Contract.

\subsubsection{Capability Check}

The Government reserves the right to check laboratory equipment in the proposed laboratory for compliance with the standards set forth in the contract specifications and to check the laboratory technician's testing procedures and techniques. If the selected laboratory fails the capability check, the contractor shall be responsible for costs associated with a capability recheck.

\subsubsection{Onsite Laboratory}

The Government reserves the right to utilize the Contractor's control testing laboratory and equipment to make assurance tests, and to check the Contractor's testing procedures, techniques, and test results at no additional cost to the Government.

\subsection{COMPLETION INSPECTION}

\subsubsection{Punch-Out Inspection}

Near the end of the work, or any indicated phase of the work, the CQC Manager shall conduct an inspection of the work. A punch list of items which do not conform to the approved drawings and specifications shall be prepared and included in the CQC documentation, as required by paragraph DOCUMENTATION. The list of deficiencies shall include the estimated date by which the deficiencies will be corrected. The CQC Manager or staff shall make a second inspection to ascertain that all deficiencies have been corrected. Once this is accomplished, the Contractor shall notify the Government that the facility is ready for the Government Pre-Final inspection.

\subsubsection{Pre-Final Inspection}


The Government will perform the pre-final inspection to verify that the facility is complete and ready to be occupied. A Government Pre-Final Punch List may be developed as a result of this inspection. The Contractor's CQC Manager shall ensure that all items on this list have been corrected before notifying the Government, so that a Final inspection with the customer can be scheduled. Any items noted on the Pre-Final inspection shall be corrected in a timely manner. These inspections and any deficiency corrections required by this paragraph shall be accomplished within the time slated for completion of the entire work or any particular increment of the work if the project is divided into increments by separate completion dates.

\subsubsection{Final Acceptance Inspection}

The Contractor's Quality Control Inspection personnel, plus the superintendent or other primary management person, and the Contracting Officer's Representative shall be in attendance at the final acceptance inspection. Additional Government personnel including, but not limited to, those from Facility Engineer user groups, and Program Offices may also be in attendance. The final acceptance inspection will be formally scheduled by the Contracting Officer based upon results of the Pre-Final inspection. Notice shall be given to the Contracting Officer at least 14 days prior to the final acceptance inspection and shall include the Contractor's assurance that all specific items previously identified to the Contractor as being unacceptable, along with all remaining work performed under the contract, will be complete and acceptable by the date scheduled for the final acceptance inspection. Failure of the Contractor to have all contract work acceptably complete for this inspection will be cause for the Contracting Officer to bill the Contractor for the Government's additional inspection cost in accordance with the contract clause titled "Inspection of Construction".

\subsection{DOCUMENTATION}

The Contractor shall maintain current records providing factual evidence that required quality control activities and/or tests have been performed. These records shall include the work of subcontractors and suppliers and shall be on an acceptable form that includes, as a minimum, the following information:

a. Contractor/subcontractor and their area of responsibility.

b. Operating plant/equipment with hours worked, idle, or down for repair.

c. Work performed each day, giving location, description, and by whom. When Critical Path Network Analysis is used, identify each phase of work performed each day by the activity number.

d. Test and/or control activities performed with results and references to specifications/drawings requirements. The control phase shall be identified (Preparatory, Initial, Follow-up). List of deficiencies noted, along with corrective action. 
e. Quantity of materials received at the site with statement as to acceptability, storage, and reference to specifications/drawings requirements.

f. Submittals and deliverables reviewed, with contract reference, by whom, and action taken.

g. Offsite surveillance activities, including actions taken.

h. Job safety evaluations stating what was checked, results, and instructions or corrective actions.

i. Instructions given/received and conflicts in plans and/or specifications.

j. Contractor's verification statement.

These records shall indicate a description of trades working on the project; the number of personnel working; weather conditions encountered; and any delays encountered. These records shall cover both conforming and deficient features and shall include a statement that equipment and materials incorporated in the work and workmanship comply with the contract. The original and one copy of these records in report form shall be furnished to the Government daily within 24 hours after the date covered by the report, except that reports need not be submitted for days on which no work is performed. As a minimum, one report shall be prepared and submitted for every 7 days of no work and on the last day of a no work period. All calendar days shall be accounted for throughout the life of the contract. The first report following a day of no work shall be for that day only. Reports shall be signed and dated by the CQC System Manager. The report from the CQC Manager shall include copies of test reports and copies of reports prepared by all subordinate quality control personnel.

\subsection{SAMPLE FORMS}

Prior to commencing work on construction, the Contractor can obtain a single copy set of the current report forms from the Contracting Officer. The report forms will consist of the Contractor Production Report, Contractor Production Report (Continuation Sheet), Contractor Quality Control Report, Contractor Quality Control Report (Continuation Sheet), Preparatory Phase Checklist, Initial Phase Checklist, Rework Items List, and Testing Plan and Log. Other reports may be in formats customarily used by the Contractor, Testing Laboratories, etc. and will contain the information required by this specification.

\subsection{NOTIFICATION OF NONCOMPLIANCE}

The Contracting Officer will notify the Contractor of any detected noncompliance with the foregoing requirements. The Contractor shall take immediate corrective action after receipt of such notice. Such notice, when delivered to the Contractor at the work site, shall be deemed sufficient for the purpose of notification. If the Contractor fails or refuses to comply promptly, the Contracting Officer may issue an order stopping all or part of the work until satisfactory 
corrective action has been taken. No part of the time lost due to such stop orders shall be made the subject of claim for extension of time or for excess costs or damages by the Contractor.

END OF SECTION 01401 


\section{PART 1 GENERAL}

\subsection{GENERAL SAFETY PROVISIONS}

The requirements of this Section apply to, and are a component part of, each section of the specifications.

\subsubsection{NASA's Commitment to Safety}

The success of this historic agency starts with an unwavering commitment to safety. The culture of this institution is one of safe accomplishment of our missions, including construction projects. If something about this project, or any task, is unclear, it is required that you, the Contractor, ask for clarification. No activities on this project, or at this Agency, are important enough to compromise the safety of any person. If you suspect something isn't quite right, trust your instincts and your experience, and do something to correct the situation.

NASA's mission success starts with safety. A commitment to safety permeates everything we do. We are committed to protecting the safety and health of the general public, pilots and astronauts, the NASA workforce, and our high-value assets on and off the ground.

\subsubsection{The Dryden Safety Culture}

Safety at the Dryden Flight Research Center is of paramount concern. We assure a commitment to safety by employing systems and processes that ensure the safety of the public, the employees, and assets. We ensure safety in all aspects of personal endeavors and we are committed to ensuring the safety of others. We take ownership for safety. We know every accident is preventable. In the spirit of the Dryden Flight Research Center, the Contractor shall implement the safety provisions of this section to "make known the overlooked and unexpected" to keep all employees safe. The Contractor shall INSTRUCT ALL EMPLOYEES as to the hazards and the precautions to be taken in performance of this contract. The Contractor shall provide and maintain work environments and procedures which will safeguard Contractor employees, Subcontractors, the Public, Government personnel, and Government property, materials, supplies, and equipment exposed to Contractor operations and activities.

\subsubsection{Construction Safety Goals}

The safety provisions of this section are to be implemented by the Contractor so that:

a. Everyone involved in this project goes home as healthy as they arrived.

b. This construction work site is free of recognizable hazards.

c. We have zero lost-time accidents. 
d. We have zero injuries in our workplace.

\subsubsection{Construction Safety Strategy}

In order to meet these goals every individual working onsite for the Contractor, including Subcontractors, Vendors and their employees, shall:

a. Be involved in making this project safer.

b. Know how to identify hazards.

c. Know how to report hazards and get them fixed.

d. Know their safety and health training needs, have obtained that training, and shall put the concepts to work each and every day while working on this project.

\subsubsection{Compliance}

The Contractor shall take safety and health measures in performing work under this Contract. The Contractor shall comply with all applicable federal, NASA/Dryden Flight Research Center (DFRC), and Edwards Air Force Base occupational safety and health requirements and standards. The Contractor shall take all precautions in the performance of work under this contract to protect the safety and health of the Contractor's employees, to protect the safety and health of all persons in or near the jobsite, and to prevent damage to property, materials, supplies and equipment. The Contractor shall comply with Federal OSHA Safety and Health Standards 29 CFR 1910 and 29 CFR 1926. The Contractor shall comply with the U.S. Army Corps of Engineers Safety and Health Requirements Manual in effect on the date of the solicitation.

\subsection{REFERENCES}

The publications listed below form a part of this section and are documents that must be complied with in the performance of this contract:

\section{U.S. NATIONAL ARCHIVES AND RECORDS ADMINISTRATION (NARA)}

29 CFR 1910

29 CFR 1926
Occupational Safety and Health Standards

Safety and Health Regulations for Construction

\section{U.S. ARMY CORPS OF ENGINEERS (USACE)}

COE EM-385-1-1
(2003) U.S. Army Corps of Engineers Safety and Health Requirements Manual, most recent version in effect on the date of the solicitation 
The publications listed below form a part of this section to the extent referenced:

NATIONAL AERONAUTICS AND SPACE ADMINISTRATION (NASA)

NASA NPG 8621.1

(2000) NASA Mishap Reporting, Investigating and Record Keeping Policy

NASA NPG 8715.3

(2000) NASA Safety Manual

NASA NSS 1740.12

(1993) NASA Safety Standard For Explosives, Propellants and Pyrotechnics

U.S. NATIONAL ARCHIVES AND RECORDS ADMINISTRATION (NARA)

10 CFR 20

(2002) Standards for Protection Against Radiation

\subsection{SUBMITTALS}

Government approval is required for submittals with a "G" designation; submittals not having a "G" designation are for information only or as otherwise designated. The following shall be submitted in accordance with Section 01330 SUBMITTAL PROCEDURES:

SD-01 Preconstruction Submittals

The following items shall be submitted in accordance with Paragraphs 1.3.1 "Accident Prevention Plan" and 1.3.2 "Activity Hazard Analysis" of this section. (See also

Paragraph 1.4.1 "Documents at the Jobsite" of this section.)

Accident Prevention Plan

Activity Hazard Analysis

The following Requests for Permit shall be submitted in accordance with Paragraph 1.8 "PERMIT REQUIRED OPERATIONS" of this section.

Request for Excavation and Digging Permit

Request for Open Flame and Hot Work Permit

Request for Confined Space Entry Permit

Request for Utility Outage/Facility Closure Permit

Request for Crane Operation Permit 


\section{SD-07 Certificates}

The following shall be submitted with the Contractor's "Daily Report to the Inspector" (see Section 01010 "Standard Requirements" Paragraph 1.4 "Daily Report to the Inspector") by 10:00 am the next work day in accordance with Paragraph 1.5.2 "Daily Safety Meetings/Daily Safety Inspections" of this section:

Safety Meeting/Safety Inspection sheets

Safety Meeting Attendance sheets

Confined Space Entry Training Certificates shall be submitted for all Confined Space Entry Attendants/Entry Supervisors prior to any employees entering a confined space. (See also Paragraph 1.4.1 "Documents at the Jobsite" of this section.)

\section{SD-08 Manufacturer's Instructions}

Material Safety Data Sheets (MSDS) for all chemicals and hazardous materials brought to the jobsite. MSDSs shall be submitted in accordance with Paragraph 1.3.3 "Material Safety Data Sheets (MSDS)" and Paragraph 1.14.2 "Chemicals and Hazardous Materials" of this section. (See also Paragraph 1.4.1 "Documents at the Jobsite" of this section.)

\subsubsection{Accident Prevention Plan}

The Contractor shall submit a written proposed Accident Prevention Plan before commencing the work. The Contractor shall submit this written Accident Prevention Plan to the Contracting Officer for approval. The Contractor shall submit this written Accident Prevention Plan within 15 calendar days after notice to proceed. The Accident Prevention Plan, written by the prime Contractor for the specific work and hazards of this contract, shall implement in detail the pertinent requirements of the US Army Corps of Engineers Safety and Health Requirements Manual. The plan shall define how the Contractor will comply with Federal OSHA Safety and Health Standards 29 CFR 1910 and 29 CFR 1926. Prior to initiation of work at the job site, the Contractor's Accident Prevention Plan shall be reviewed, found acceptable, and approved by the Contracting Officer.

The Contractor's Accident Prevention Plan shall be written and executed in accordance with the Occupational Safety and Health Administration requirements. Any deviation shall be coordinated with the Contracting Officer before being exercised.

The Accident Prevention Plan shall be NASA/DFRC site specific and include, as a minimum, the following:

a. Safety program objectives.

b. Methods to attain safety objectives. 
c. Responsibility of key personnel for the Contractor.

d. Safety meetings, surveys, inspections, and reports.

e. Disaster and emergency programs as it applies to the NASA/DFRC site.

f. A map with the location and times of operation of the NASA/DFRC medical dispensary. (This information can be obtained from the Contracting Officer.)

g. Lists of key personnel to be contacted in times of emergency, along with appropriate phone numbers to be used in emergencies.

h. Program to show compliance with Federal OSHA Safety and Health Standards 29 CFR 1910 and 29 CFR 1926 and various safety requirements of NASA NPG 8715.3 and COE EM-385-1-1.

i. Methods to comply with the requirement for immediate reporting of accidents to the Contracting Officer in accordance with NASA NPG 8621.1.

j. Statement that the Contractor will not invalidate the integrity of safety systems without proper authorization.

k. Procedures for emergency actions to be taken in the event of accident or an act of nature. This shall include procedures to secure dangerous conditions, protect personnel, and secure work areas. The plan must contain 911 telephone contact procedures specific to NASA/DFRC (See Paragraph 1.19 "FIRST AID AND EMERGENCIES" of this section).

1. Procedures for securing the accident site so that the area remains secure until arrival of a safety investigator. Accident site will remain secured until released by the Contracting Officer.

m. Procedures describing how chemicals, hazardous materials and hazardous wastes will be handled, managed and disposed of while at NASA/DFRC.

n. Incorporate plans for the following, as applicable: Lockout/Tagout, Confined Space, Fire Prevention, Electrical Safety, and Fall Prevention/Protection.

o. Incorporate a comprehensive site-specific heat stress monitoring plan. Drinking water shall be made available to workers and workers shall be encouraged to frequently drink small amounts; the water shall be kept reasonably cool.

\subsubsection{Activity Hazard Analysis}

Prior to beginning each major phase of work, an activity hazard analysis shall be prepared by the Contractor performing the work. A major phase of work is defined as an operation involving a type of work presenting hazards not experienced in previous operations or where a new 
subcontractor or work crew is to perform. Work will not proceed on that phase until the activity hazard analysis has been accepted by the Contracting Officer and discussed with all engaged in the activity, including the Contractor, subcontractors, and government on-site representatives.

The Activity Hazard Analysis shall:

a. define the activity to be performed and identify the sequence of work,

b. define the specific hazards anticipated with the activity,

c. define the control measures to be implemented to eliminate or reduce each hazard to an acceptable level,

d. identify the equipment to be used,

e. identify the inspection requirements for that equipment and activity, and

f. list the training requirements for the workers.

\subsubsection{Material Safety Data Sheets (MSDS)}

Provide the Contracting Officer with a copy of the Material Safety Data Sheets for all chemicals and hazardous materials to be brought on site. All manufacturer's recommended precautions shall be followed during the use of any chemical and hazardous material. MSDSs must be submitted to the Contracting Officer for approval prior to the use of any chemical or hazardous substance. See also Paragraph 1.4.1 "Documents at the Jobsite" and Paragraph 1.14.2 "Chemicals and Hazardous Materials" of this section.

\subsection{SAFETY COMMUNICATIONS}

Safety plans, hazard analyses, and MSDSs are only effective when the workers in the field are aware of the potential hazards for that day, and take mitigation measures to work safely in that area at that time. Therefore, daily safety communications are a critical requirement. Every work day shall begin with a brief safety meeting and every work day shall include a safety inspection by the Contractor's Site Safety Officer, see Paragraph 1.5.2 "Daily Safety Meetings/Daily Safety Inspections".

Also, prior to beginning any new class of work the Contractor shall conduct an Activity Hazard Analysis on that new class of work and shall conduct a thorough discussion of that Activity Hazard Analysis with the workers performing the work. The Contractor shall ensure the workers understand the hazards and how to use any special tools, unique equipment, and personal protective equipment. Only after these safety analyses and communications occur shall the new class of work be allowed to proceed.

\subsubsection{Documents at the Jobsite}


To help maximize safety communications, the following list of documents shall be maintained on the jobsite and made easily available for the Contractor's employees and Subcontractors' employees. These records shall also be made available for Government inspection. They include but are not limited to:

a. the approved Accident Prevention Plan,

b. all approved Activity Hazard Analysis,

c. all approved MSDSs,

d. all approved permit documents for Permit Required Operations that have been completed,

e. all records of lockout/tagout operations that have been completed,

f. the jobsite OSHA $300 \log$,

g. all training records, including Confined Space Entry Training Certificates, and

h. other records that are deemed appropriate due to the nature of the work, i.e. certificates, permits, licenses, etc.

These records shall be stored at a convenient centralized location on the jobsite. These records shall be organized, filed, and labeled in binders or file folders in a fashion that all persons involved with the project can obtain the information quickly and easily.

\subsubsection{Posted Warnings and Prohibitions}

The Contractor shall comply with procedures prescribed for control and safety of all persons visiting the project site. The contractor shall install all barricades and signs needed. All points of entry to the project site shall have a sign warning of the requirement to wear hard hats. The Contractor is responsible for familiarizing each employee and each subcontractor employee with safety requirements.

All Contractor personnel are to obey all posted prohibitions, restrictions, warnings, and traffic control signs and devices. Contractor personnel shall not enter any area in which a red light is flashing without permission of the NASA area supervisor. When alarm bells are sounded in a building, secure the equipment in use and leave the building by the nearest exit. An egress passage must be maintained at all times in the work area. The Contractor shall advise employees of these requirements.

The Contractor shall advise the Contracting Officer of any special safety restrictions the Contractor has established so that Government personnel can be notified of these restrictions.

\subsubsection{Display of Safety Information}


The Contractor shall erect a safety bulletin board at the job site within 2 calendar days after the Contracting Officer has approved the Accident Prevention Plan. The following information shall be displayed on the safety bulletin board in clear view of the on-site construction personnel, maintained current, and protected against the elements and unauthorized removal:

a. Map denoting the route to the nearest emergency care facility.

b. Emergency phone numbers.

c. Copy of the most up-to-date Accident Prevention Plan.

d. Current AHA(s) and MSDSs.

e. OSHA 300A Form.

f. OSHA Safety and Health Protection-On-The-Job Poster.

g. Safety and Health Warning Posters.

h. Active Permits.

1. Excavation and Digging,

2. Open Flame and Hot Work,

3. Confined Space Entry,

4. Utility Outages/Facility Closures

5. Crane Operations.

i. A sign indicating the number of years and days without a lost time construction accident at NASA's Dryden Flight Research Center.

\subsubsection{TRAINING}

\subsubsection{New Employee Indoctrination}

New employees (prime, subcontractor, vendors, suppliers) onsite will be informed of specific site hazards before they begin work. Documentation of this orientation shall be kept on file at the project site.

\subsubsection{Periodic Training}


Provide Safety and Health Training in accordance with USACE EM 385-1-1 and the approved Accident Prevention Plan. Ensure all required training has been accomplished for all onsite employees.

\subsubsection{Training on Activity Hazard Analysis (AHA)}

Prior to beginning a new phase, training will be provided to all affected employees to include a review of the AHA to be implemented.

\subsection{SAFETY MEETINGS AND INSPECTIONS}

\subsubsection{Mutual Understanding Meeting}

Before commencing the work, the Contractor shall meet with representatives of the Contracting Officer to discuss and develop a mutual understanding relative to administration of the overall safety program. Items to be discussed shall include: COE EM-385-1-1, hard hats/safety shoes, other personal protective equipment (PPE), daily safety meetings, activity hazard analysis, frequency of inspections, 911 communications, stopping of unsafe activities, permit required operations and MSDSs.

\subsubsection{Daily Safety Meetings/Daily Safety Inspections}

The Contractor shall conduct daily safety meetings at the beginning of each work shift. This safety meeting shall be administered by the Contractor's Site Safety Officer and/or Job Superintendent, or qualified designated representatives of these elements. This safety meeting shall be attended by all of the Contractor's employees, as well as all subcontractors and their employees working at the project site for that day. If any of these persons are not present at the daily safety meeting, they shall be briefed of the issues discussed in the meeting on an individual basis by the Contractor's Site Safety Officer prior to starting work at the site that day. The safety meeting format and discussion shall include, but not be limited to: the schedule of events on the site for the day; addressing hazard analyses for the day's activities; allowing employees and subcontractors to submit hazard analyses and MSDSs for upcoming activities; planning permit required operations; discussing unsafe conditions and near misses on the job site; discussing new equipment and material deliveries to the job site; discussing corrective actions to be taken and assignment of responsibilities for the implementation of those corrective actions.

The Contractor's designated Site Safety Officer shall, at least once per shift, conduct at least one walk-through site safety inspection of all site activities. This inspection shall be conducted at a random time during each shift. The Site Safety Officer's sole purpose during the walk-through shall be to ensure compliance with the approved Accident Prevention Plan, approved Activity Hazard Analysis, and approved MSDSs. Additionally the Site Safety Officer must ensure the workers receive feedback as to their safety effectiveness and compliance with safety procedures.

The Contractor shall use the attached Safety Meeting/Safety Inspection sheets and Safety Meeting Attendance sheets, or an approved equal, to report the elements described herein. These sheets shall be submitted to the Contracting Officer on a daily basis by 10:00 am on the next 
work day, (with the Contractor's "Daily Report to the Inspector", see Section 01010 "Standard Requirements" Paragraph 1.4 "Daily Report to the Inspector").

\subsection{CONTRACTOR VEHICLES AND EQUIPMENT}

Edwards AFB access passes for Contractor owned vehicles are issued at the Military Security Police building (Building 2860) on the main base. A letter from the Contracting Officer is required along with proof of registration and insurance, as well as a valid driver's license.

Contractor-owned, leased, or operated equipment must be in satisfactory mechanical condition. While in use at the job site, rental equipment shall be kept in good working order and properly maintained. Contractor owned equipment brought on site must have copies of all operating air permits for the equipment.

Prior to a piece of rental equipment arriving on the job site, the Contractor shall present a hazard analysis for the use of the equipment. The hazard analysis shall include consideration for hazards associated with unloading, moving, and reloading the equipment. The Contractor is responsible to ensure that all employees working on or around that equipment are properly trained to use it and made aware of its associated hazards.

Hoisting and lifting devices and cranes must bear evidence of proof loading within the preceeding 12 months. Operators of hoisting and lifting devices and cranes shall be trained in proper use and safety limitations. The Contractor shall provide written proof of qualification for all operators of fork lifts and personnel lifts (i.e. boom lifts, platform lifts, scissors lifts, etc.). Outdoor hoisting operations shall not commence if winds are above 20 knots $(23 \mathrm{mph})$ steady state or if gusts exceed 35 knots $(40 \mathrm{mph})$ and the Contractor shall also comply with the manufacturer's recommended operating limits; the more restrictive shall govern.

Crane operators shall meet the requirements in USACE EM 385-1-1, Section 16 and Appendix G. In addition, for mobile cranes, crane operators shall be designated as qualified by a source that qualifies crane operators (i.e., union, a government agency, or and organization that tests and qualifies crane operators). Written proof of current qualification shall be provided.

Contractor owned vehicles which will be driven on the flight line (aircraft hangars, aprons, ramps, tow-ways, and taxiways) must bear identifying signs and property damage insurance. Access to the flight line must be authorized by the Contracting Officer. The Contractor shall be responsible for performing daily inspections of these vehicles and shall secure, remove, or dispose of all foreign objects, materials, and debris that can cause damage to an aircraft. Objects and debris lodged between tire treads shall be removed prior to driving on the flight line. All vehicles which are permitted on aircraft maintenance ramps, fuel storage areas, fuel servicing areas, hangars, explosive areas, and any other fire hazard areas shall be equipped with an approved spark arrestor and authorized in writing by the Contracting Officer for use in these areas.

Operators of motor vehicles shall be licensed. Only Contractor work vehicles, delivery vehicles, and debris hauling vehicles, driven by licensed operators, will be allowed at the work site. 
Vehicles for transportation of personnel or personal tools (commuting) must be parked in designated parking spaces in the DFRC parking lots.

The use of seat belts is mandatory by all operators and passengers traveling in motor vehicles on Edwards Air Force Base and NASA/DFRC. Passengers are prohibited from riding in or on the back or bed of any truck. The speed limit, unless otherwise posted, is 15 miles per hour. The security police use radar units.

Use of Government owned equipment, tools, supplies, or materials is prohibited unless specifically authorized by the Contracting Officer.

\subsection{PROTECTION OF EXISTING UTILITIES}

Existing utilities that are indicated, or the location of which is made known to the Contractor prior to beginning of operations, and utility lines constructed during the Contractor's operation, shall be protected from damage. If the Contractor damages any of these utilities they shall be repaired by the Contractor at no additional cost to the Government. In the event that the Contractor damages any existing utility lines that are not indicated or the locations of which are not known to the Contractor, report thereof shall be made immediately to the Contracting Officer. If the Contracting Officer determines that repairs shall be made by the Contractor, such repairs will be ordered under the clause of the general provisions of the contract entitled "Differing Site Conditions".

\subsection{PERMIT REQUIRED OPERATIONS}

The Contractor shall coordinate with the Contracting Officer and obtain written approval from the Contracting Officer on all Permit Required Operations before the operation begins. The Contractor shall initiate coordination with the Contracting Officer by writing and submitting a Request for Permit. The Contractor shall provide, with the Request for Permit the following:

a. Work Plan - A written work plan describing the work to be accomplished during the Permit Required Operation including a schedule to be followed. The schedule shall include the dates and time period the Contractor contemplates performing the operation.

b. Activity Hazard Analysis - An activity hazard analysis of the proposed activities during the Permit Required Operation including the Contractor's plan to minimize or eliminate any hazards associated with the performance of the work. See paragraph 1.3.2.

The permits are primarily used to identify potentially hazardous work conditions in an attempt to prevent accidents. The permits are also used to coordinate the required work with key DFRC activities and keep customer inconvenience to a minimum. The permits shall be processed just prior to the start of the operation. Permit forms will be provided and filled out by the Government. The Contractor shall post approved permits at a conspicuous location in the construction area near the permitted operation. Upon completion of the Permit Required Operation a copy of the approved permit documents shall be stored at the jobsite in accordance with Paragraph 1.4.1 "Documents at the Jobsite" of this section. Permit required operations are: 
1. Excavation and Digging,

2. Open Flame and Hot Work,

3. Confined Space Entry,

4. Utility Outages/Facility Closures, and

5. Crane Operations.

\subsubsection{Excavation and Digging}

Surface penetration, excavation, digging, and trenching are Permit Required Operations. Surface penetration, excavation, digging, and trenching operations must be approved by the Contracting Officer before operations begin. The Contractor shall obtain this approval by submitting a written Request for Excavation and Digging Permit in accordance with Paragraph 1.8 "PERMIT REQUIRED OPERATIONS". The Contractor shall submit this request to the Contracting Officer seven (7) calendar days prior to the start of digging operations, to enable the Contracting Officer to review measures being taken to prevent hazard to employees and possible damage to subsurface utilities.

The permit, a NASA - DRYDEN FACILITIES ENGINEERING WORK CLEARANCE REQUEST (Dryden form FM-8), must be filled out by the Government and attached to the Contractor's Request for Excavation and Digging Permit. This package must be reviewed and approved by several DFRC and USAF organizations prior to start of surface penetration, excavation, digging, or trenching. During this review and approval period the Contractor can proceed with marking and staking activities described below.

Prior to performing any surface penetrations, excavation, digging, or trenching 6 inches or deeper (including driving stakes more than 6 inches in the ground) on any ground surface, the Contractor shall obtain from the Contracting Officer the current subsurface utility drawing of the particular area to be worked on. All utility lines shall be identified and marked in the field. The Contractor shall stake out, mark, paint lines, or other wise identify all subsurface pressurized gas pipes, high voltage cables, communication cables, other pipe lines, and other subsurface structures indicated within the area of the work before any surface penetration, excavation, digging, or trenching is done. After identification is complete, the Contractor shall obtain agreement from the Contracting Officer that identification is sufficient. After obtaining the approved permit package from the Contracting Officer and completing the marking and staking activities, the Contractor shall proceed with the excavating and digging operation in accordance with the approved permit documents.

The Contractor, however, shall temporarily halt any powered equipment digging and machine excavation work (i.e. backhoe, jackhammer, trencher, auger, etc.) when approaching within 10 feet of the staked-out/marked utility until the Contractor has exposed the utility by hand excavation to fix its location. The utility must be exposed using hand digging methods, i.e. "pot 
holing" with pick and shovel with care. The Contractor shall obtain agreement from the Contracting Officer on how much closer to the utility the machine excavations can be allowed. Powered equipment digging shall not be performed within 5 feet of any utility. All powered equipment must be positioned so that it cannot come any closer than 5 feet from the utility. Backhoes must be positioned so that when the arm is in the full extension it cannot come any closer than 5 feet to the utility and the arm must always be drawn away from the utility thus pulling material toward the operator and away from the utility.

\subsubsection{Open Flame and Hot Work}

The use of an open flame is a Permit Required Operation. Hot work such as welding, torch cutting, sawing metals, flame cutting, burning, grinding, brazing, soldering, and cad welding are all Permit Required Operations. Applying, installing, or removing building materials through the use of heat are also Permit Required Operations. Any operation that can result in the generation of hot flying debris or sparks is a Permit Required Operation. During operations involving possible fire hazard, the Contractor shall notify the Contracting Officer and not proceed until approval is obtained in writing. Open flame and hot work operations must be approved by the Contracting Officer before operations begin. The Contractor shall obtain this approval by submitting a written Request for Open Flame and Hot Work Permit in accordance with Paragraph 1.8 "PERMIT REQUIRED OPERATIONS". The Contractor shall submit this request to the Contracting Officer three (3) calendar days prior to the start of these operations, to enable the Contracting Officer to review measures being taken to prevent hazard to employees, prevent possible fire damage to equipment and property, and prevent unnecessary activation of fire suppression/alarm systems.

The permit, a USAF WELDING, CUTTING AND BRAZING PERMIT, (AF Form 592), must be filled out by the Government and attached to the Contractor's Request for Open Flame and Hot Work Permit. This package must be reviewed and approved by the Dryden Safety Office and approved by the Contracting Officer prior to start of open flame and hot work. After obtaining the approved permit package from the Contracting Officer, the Contractor shall proceed with the open flame and hot work operation in accordance with the approved permit documents. The Contractor or Subcontractor performing the operation shall sign the permit before any open flame and hot work operation is started. The Contractor shall also comply with the requirements stated below.

The Contractor shall discontinue open flame or hot work operations 30 minutes prior to the end of the normal work day. A Contractor employee shall be assigned as Fire Watchman for every open flame and hot work operation. The Watchman shall be equipped with suitable fire extinguishers and shall check all areas around and below the welding or burning operation for fires. The check shall be continued for at least 30 minutes after completion of the open flame or hot work operation to ensure no possible sources of latent combustion.

The Contractor shall provide portable fire extinguishers for fire safety during open flame and hot work operations. When conducting open flame and hot work operations on roofs, the Contractor shall provide and be equipped with one full 20 pound 20-A:120 BC multipurpose dry chemical fire extinguisher and one 2.5 gallon water pressure/spray-pump type portable fire extinguisher 
placed within 30 feet of the operation. For all other open flame and hot work operations the Contractor shall provide and be equipped with one full 10 pound 4-A:60 BC multipurpose dry chemical fire extinguisher and one 2.5 gallon water pressure/spray-pump type portable fire extinguisher placed within 30 feet of the operation. The Contracting Officer may request a standby from the Edwards Fire Department; this accommodation does not relieve the Contractor of responsibility for open flame and hot work safety.

\subsubsection{Confined Space Entry}

Entering a confined space is a Permit Required Operation. Entering a manhole, underground vault, sewage pit, vessel, tank, subfloor area, or other confined space is a permit required operation. Safety clearance from the Contracting Officer is required before any Contractor personnel enter a manhole or vault or any other confined space. Entry must be assessed under Confined Space guidelines. Permit Required Confined Space regulations shall be followed during all confined space entries. Confined space operations must be approved by the Contracting Officer before operations begin. The Contractor shall obtain this approval by submitting a written Request for Confined Space Entry Permit in accordance with Paragraph 1.8 "PERMIT REQUIRED OPERATIONS". The Contractor shall submit this request to the Contracting Officer three (3) calendar days prior to the start of these operations, to enable the Contracting Officer to review measures being taken to prevent hazard to employees.

The permit, a CONFINED SPACE ENTRY PERMIT (forms DFRC-223, DFRC-224, and/or DFRC-225), must be filled out by the Government and attached to the Contractor's Request for Confined Space Entry Permit. This package must be reviewed and approved by the Dryden Safety Office and approved by the Contracting Officer prior to entry. After obtaining the approved permit package from the Contracting Officer, the Contractor shall proceed with the confined space operation in accordance with the approved permit documents. The Contractor shall also comply with the requirements stated below.

All work within manholes and other confined spaces shall be considered permit required confined space entry work, unless otherwise designated by the Contracting Officer. Contractor shall be responsible for removing water and debris before commencement and during execution of work in manholes and vaults. The Contractor shall have one or more confined space entry attendants/entry supervisors who are properly trained in the operation of gas monitoring equipment and formally qualified as confined space entry attendants/entry supervisors who shall be on duty during times workmen are in confined spaces. Their primary functions shall be to monitor the confined space. Gas monitoring shall be performed prior to entry and continuously when anyone is in the confined space. Readings shall be permanently recorded daily, indicating the concentration of gas, location and time the space was monitored.

Special requirements, coordination, and precautions will apply to areas that contain a hazardous atmosphere or, by virtue of their use or physical character, may be oxygen deficient. A breathing hazard check by the Government is required prior to entering areas that contain a hazardous atmosphere or, by virtue of their use or physical character, may be oxygen deficient. Surveillance and monitoring shall be required in these types of workspaces by both Contractor and Government personnel. 


\subsubsection{Utility Outages/Facility Closures}

Turning a utility off or on is a Permit Required Operation. Closing a facility or part of a facility is a Permit Required Operation. Streets, walks, and other facilities occupied and used by the Government shall not be closed or obstructed without written permission from the Contracting Officer. Utility outages and facility closures must be approved by the Contracting Officer before outages and closures begin. The Contractor shall obtain this approval by submitting a written Request for Utility Outage/Facility Closure Permit in accordance with Paragraph 1.8 "PERMIT REQUIRED OPERATIONS". The Contractor shall submit this request to the Contracting Officer fourteen (14) calendar days in advance of the planned outage or closure, to enable the Contracting Officer to review measures being taken to prevent hazard to employees and the public, to prevent interruption of any required service, to coordinate the required work with key DFRC activities, and keep Center impact to a minimum.

The permit, a DRYDEN UTILITY SYSTEM OUTAGE APPROVAL (form DFRC-113), must be filled out by the Government and attached to the Contractor's Request for Utility Outage/Facility Closure Permit. This package must be reviewed and approved by the Dryden Safety Office, the Dryden Maintenance and Logistics Branch, the affected Building/Area Manager, and the Contracting Officer prior to initiation of the outage or closure. Notification must also be made to the DFRC Security Office, the DFRC Information Systems Branch, and Center Management. After obtaining the approved permit package from the Contracting Officer, the Contractor shall proceed with the work requiring an outage or closure in accordance with the approved permit documents. The Contractor shall also comply with the requirements stated below.

The shut-down and start-up of the utilities for the outage shall be performed by the government and not the Contractor.

\subsubsection{Crane Operations}

Operating a crane is a Permit Required Operation. Setting up a crane is a Permit Required Operation. Cranes shall not be operated without written permission from the Contracting Officer. Crane operations must be approved by the Contracting Officer before crane setup begins. The Contractor shall obtain this approval by submitting a written Request for Crane Operation Permit in accordance with Paragraph 1.8 "PERMIT REQUIRED OPERATIONS". The Contractor shall submit this request to the Contracting Officer fourteen (14) calendar days in advance of the planned crane operation to enable the Contracting Officer to review measures being taken to prevent hazard to employees and the public, to prevent interruption of any required service, to coordinate the required work with key DFRC activities, and keep Center impact to a minimum.

The permit, a CRANE OPERATION APPROVAL (form FD 8), must be filled out by the Government and attached to the Contractor's Plans. The contractor shall prepare the following plans/documents: 


\section{Description of Work,}

List the work to be accomplished during the lifting operation

2. Center Impact Analysis,

List the affects this activity will have on Center occupants and Center operations, i.e. evacuate portions of a building, close a fire lane, require special secure access, close a building exit/entrance, etc.

3. Activity Hazard Analysis

Per paragraph 1.3.2.

\section{Lift Plan}

a. The exact size and weight of the load.

b. The maximum load limits for the entire range of the lift.

c. Height of the lift.

d. The lift geometry and sequence of actions.

e. The load radius.

f. The boom length and angle, for the entire range of the lift.

g. Ground conditions and outrigger and mats requirements.

h. A drawing showing the location of the crane and the "from" and "to" pick points, including adjacent buildings, utilities, and other obstructions or hazards.

i. Rigging procedures and rigging hardware.

j. Proof of qualification for the crane operator.

k. Environmental conditions under which lift operations are to be stopped.

1. Communication and coordination requirements.

m. The Contractor shall make Personnel Assignments and clearly list by name who will be the Lift Director, Crane Operator, Signalman, Rigger, and Tag Line Persons.

n. The Contractor shall also complete the Crane Safety Checklist prior to commencing lifting operations. 
o. The Contractor shall perform a practice pick without the load to verify estimated boom angle(s) required to pick, rotate, and set the load.

This package must be reviewed and approved by the Dryden Lift Supervisor and the Chief of Facilities Design and Contruction Branch prior to initiation of the crane setup. The Chief of Facilities Design and Construction Branch will assign the Lift Supervisor. Notification must also be made, by NASA project personnel, to the DFRC Security Office, the DFRC Safety Office, and Center Management prior to lifting operations. After obtaining the approved permit package from the Contracting Officer, the Contractor shall proceed with the crane operation in accordance with the approved permit documents.

Crane Safety Checklist for Facility Lifts:

\section{Things to check}

1. Crane certifications have been checked and are current.

2. Operator certifications have been checked and are current.

3. Ancillary lifting equipment certifications (slings, chokers, etc.) are current.

4. Boom angle needed to reach both pick point and set points have been checked and capacity of the crane (AT THOSE BOOM ANGLES) are sufficient to lift the intended load. 5. Capacity of the crane at the horizontal angles required for the pick, rotation, and set have been checked against crane manual and capacity is sufficient for the intended load. (Note: Some cranes, especially crawler cranes that don't have outriggers, DO NOT have the same capacity to the side that they do to the front.)

6. There is sufficient room for crane counterweights to miss all obstructions when the crane rotates horizontally.

7. Clip on crane hook has sufficient spring tension.

8. All people in area are wearing hard hats and safety shoes.

9. Person who is signaling crane operator has been designated and everyone understands who that person is for this operation.

10. lift Supervisor has been designated and everyone understands who that person is for this operation.

11. Personnel handling tag lines have been designated and they understand that they are not allowed under the load.

12. Ground where outriggers are set has sufficient capacity to resist "punching shear" force which is generated from load and expected geometric configuration of crane.

13. Check for overhead electrical lines within boom radius +20 feet. Brief Chief, Facilities Design \& Construction on proposed mitigation procedures.

14. Check for underground vaults, tanks, or utilities near the crane location that might collapse or shift causing the crane to shift or sink while under load.

15. Ensure the lifting/hazardous zone is delineated clearly to public (use cones, caution tape, fencing, or other.)

\section{Things to do}


1. Practice pick shall be made prior to actual lift in order to verify estimated boom angle(s) required to pick the load, rotate the load, and set the load. (Note: This is done without the load.)

\subsection{ELECTRICAL SAFETY}

The Contractor shall appoint an individual person to be responsible for jobsite electrical safety and to restrict entry to dangerous locations to those authorized by the Contractor jointly with the Government. Lockout/Tagout controls will be strictly enforced.

When ever possible, all lines, circuits, and equipment to be worked on shall be deenergized before work is started. If equipment or circuits cannot be deenergized, the Contractor shall provide all necessary personal protective equipment and other protective controls to work on energized lines, circuits, and equipment. Additionally, approval from the Contracting Officer shall be obtained by the Contractor prior to performing work on energized lines, circuits, and equipment.

The Contractor shall use Ground Fault Circuit Interrupters (GFCI) in all circuits used for electric tools and equipment in the construction site. The Contractor shall use GFCIs in all circuits used for temporary lighting in the construction site. GFCIs shall be installed in accordance with the most recent edition of the National Electric Code.

\subsection{LOCKOUT \& TAGOUT PROCEDURES}

The Contractor shall ensure that each employee is familiar with and complies with 29 CFR 1910.147. Specific Lockout/Tagout requirements are as follows:

a. The tags shall be the same for both lockout and tagout, and shall only be used once. The information on the tag shall be printed legibly.

b. For lockout the information shall include - name of person controlling the lock, the date the lock was put in place, telephone number of the person controlling the lock, name of the Project Inspector monitoring the work, name of the company serving as prime contractor for the work, and the name of the company for which the lock control person is employed.

c. For tagout, the above information is required plus an explanation of why a lock could not be used, and what additional safety precautions were used.

The above information shall be documented, and the record made available for inspection. Upon completion of the Lockout/Tagout Operation the documents shall be stored at the jobsite in accordance with Paragraph 1.4.1 "Documents at the Jobsite" of this section.

\subsection{FIRE PREVENTION}

Any fire hazard conditions shall be immediately reported to Contracting Officer. Any fire emergency situation shall be reported by calling 911 or the NASA/DFRC Security Post \#1 at 
(661) 276-3256. Contractor vehicles must not block or encroach upon fire truck lanes at any time. The Contractor shall provide temporary fire protection equipment for the protection of personnel and property during construction.

All work sites shall be kept clean and orderly at all times. Combustible scrap, debris, and waste materials (oily rags, paper, packaging, scrap wood, etc.) shall be stored in covered metal receptacles and removed from the worksite daily to minimize potential hazards. Flammable and combustible materials shall be stored in a manner which minimizes the risk of fire including spontaneous combustion. "No Smoking" signs shall be posted in areas where flammable or combustible material are stored.

Only approved containers and tanks shall be used for storage and handling of flammable and combustible liquid. All flammable and combustible liquids shall be kept in closed containers when not in use. Bulk drums of flammable or combustible liquids shall be grounded and bonded to containers during dispensing. The Contractor shall provide and be equipped with one full 10 pound 4-A:60 BC multipurpose dry chemical fire extinguisher placed within 20 feet where flammable/combustible liquids are stored.

The Contractor shall ensure the following are complied with when pressurized cylinders are on the jobsite:

a. Cylinder contents shall be identified with a label.

b. All cylinders shall be stored in an upright position at all times.

c. Cylinders shall be secured at all times.

d. Cylinders not in use shall have valve protector caps in place.

Smoking is not permitted in buildings or on roofs. Smoking is permitted in approved designated areas only. Smoking materials shall be disposed in an approved receptacle.

Nonspark producing tools and equipment or pneumatic type shall be utilized in fire hazardous areas such as hangars and other explosive environment areas. Burning of trash or rubbish is prohibited.

\subsection{HIGH NOISE LEVEL PROTECTION}

Operations performed by the Contractor that involve the use of equipment with output of high noise levels (jackhammers, drill hammers, generators, tractors, saws, air compressors, and explosive activated tools, etc.) shall be scheduled for weekends and/or outside normal duty hours. Contractor operations that result in noise levels above $60 \mathrm{dBA}$ in any occupied buildings (offices, laboratories, control rooms, hangars, etc.) and are disruptive to NASA/DFRC business operations shall be performed on weekends or outside normal duty hours. Use of any such equipment shall be approved in writing by the Contracting Officer prior to commencement of 
work. (Normal duty hours defined in Section 01010 "Standard Requirements", Paragraph 1.8 "Normal Duty Hours")

Contractor personnel working at NASA/DFRC may need to wear hearing protection as a result of normal aircraft operations. Sonic boom shock waves are a normal everyday occurrence at NASA/DFRC that cause momentary surprise to personnel. The Contractor shall instruct all employees to be aware of this hazard, especially working outdoors at heights.

\subsection{SEVERE STORM PREPARATION}

In the event of a severe storm warning, or indications of impending severe weather (e.g. dust storms, damaging wind, heavy rains, floods, tornados, hail, or lightning) the Contractor shall monitor weather conditions and take appropriate precautions including but not limited to:

a. Secure outside equipment and materials and place materials possible to damage in protected locations.

b. Check surrounding area, including roof, for loose material, equipment, debris, and other objects that could be blown away or against existing facilities.

c. Ensure that temporary erosion controls are adequate.

d. Secure materials and equipment that should not be exposed to, or contaminated with, dirt and dust to protect the materials and equipment from damage. This includes mechanical, electrical, and electronic equipment to ensure their function is not compromised. This also includes materials that have aesthetic purpose to ensure appearance is not damaged.

\subsection{HAZARDOUS WASTE AND MATERIALS}

When working with hazardous waste and materials, Contractor personnel must wear or use personal protective articles such as protective clothing, respiratory devices, protective shields, etc., appropriate to the task being performed. Provisions are to be made by the Contractor for continuous contact with personnel working with hazardous waste/materials in remote areas.

\subsubsection{Hazardous Waste and Industrial Waste Water}

The Contractor shall identify all wastes produced, including chemicals, paints, industrial wastewater, Petroleum/Oil/Lubricant (POL) products and solvents, and their containers, and dispose of them in approved manners. Unknown wastes will be chemically identified by the Contractor. Obtain a determination of whether the waste is hazardous from the Contracting Officer. Notify the Contracting Officer prior to taking disposal action for any hazardous waste.

For disposal, provide either laboratory analysis data documenting the chemical content of the waste or certification by appropriate organization or authority as to the chemical constituents of the waste. Document the waste type, quantity, location, and personnel/contractor/agency 
responsible so the material can be tracked from generation through ultimate disposal as required by Environmental Protection Agency under Resource Conservation and Recovery Act.

\subsubsection{Chemicals and Hazardous Materials}

No chemicals and no hazardous materials such as explosives, flammables, sources of ionizing radiation, corrosives, or toxic substances may be brought onto NASA/DFRC premises without authorization from the Contracting Officer. Provide the Contracting Officer with a copy of the Material Safety Data Sheets (MSDSs) for all chemicals and hazardous materials to be brought on site. All manufacturer recommended precautions shall be followed during the use of any chemicals and hazardous material. MSDSs will be required of all substances deemed to be hazardous by the Contracting Officer. MSDSs must be submitted to the Contracting Officer for approval prior to the use of any chemicals and hazardous substance. Explosives shall not be used or brought to the project site, with the exception of powder actuated tools and equipment.

\subsubsection{Asbestos, Lead Paint, PCBs}

Any work in or around friable asbestos containing materials, including but not limited to pipe insulation, lagging, fire proofing, floor tiles, mastic, and transite walls, must be approved by the Contracting Officer prior to commencing work. The use of any construction materials containing asbestos is prohibited.

Portions of NASA buildings may contain asbestos materials. Any work involving penetration of a hollow wall space shall be coordinated with the Contracting Officer in advance.

Any work involving the disturbance of lead containing paint must be approved by the Contracting Officer. The use of any paints containing lead or zinc chromate is prohibited.

Any work involving the disturbance of PCBs must be cleared through the Contracting Officer.

\subsubsection{Radiation Requirements}

Use of equipment containing radioactive isotopes or any nuclear sources such as density test, moisture detectors, radiography, etc. must be approved by the Dryden Safety Office and the Contracting Officer. If such equipment is to be used in the work, the Contractor must notify the Dryden Safety Office through the Contracting Officer no less than 14 days prior to the use of such equipment. During the use of such equipment the Dryden Safety Office is authorized to make periodic checks to insure that proper health precautions are being followed. If the Dryden Safety Office determines that these precautions are not being followed, the Dryden Safety Office will immediately notify the Contracting Officer to initiate corrective actions.

\subsection{BARRICADING WORK AREAS}

Areas made hazardous to workers, project personnel, the public, or other persons by Contractor operations shall be barricaded as follows: 
a. All lay down areas, excavations, breaks in roads, breaks in floors, and similar conditions shall be barricaded to prevent injury to personnel and reduce the possibility of damage to moving equipment. The Contractor shall continuously barricade all lay down areas, excavations, breaks in roads, breaks in floors, and similar conditions with temporary vertical chain link fencing or vertical plywood fencing.

b. When the lay down areas, excavations, breaks in roads, breaks in floors, and similar conditions are within 20 feet of the edge of roads, parking lots, and pedestrian routes, the Contractor shall furnish and install battery powered flasher type warning lights on a maximum spacing of not less than one flasher every 15 feet on at least one side of any excavation or opening.

c. Steel plates used to cover excavations in roadways shall be sufficient to safely support all vehicle loads.

\subsection{FALL HAZARDS}

When work is performed at heights which expose workers, project personnel, the public, or other persons to falling objects, such areas shall be barricaded, restricted, or protected.

When work is performed at heights which expose workers, and inspectors to falls, the Contractor shall provide fall protection. The Contractor shall check with the Contracting Officer before commencing roofing work or any activity on a roof and shall ensure safe work conditions. When working from an aerial lift workers shall use a body harness and lanyard system appropriately attached to the boom or basket.

\subsection{PERSONAL PROTECTIVE AND SAFETY EQUIPMENT}

All construction areas at DFRC are considered hard hat areas. All persons working on or visiting the project site shall wear hard hats.

All Contractor employees and Subcontractors shall wear clothing suitable for the weather and work conditions. The minimum for field work shall be short sleeve shirt, long trousers, and steel-toed safety boots.

For purposes of inspecting the work under this contract, the Contractor shall provide personal protective and safety equipment to the Government inspector for use during inspections. This includes but is not limited to body harnesses, lanyards, lifelines, ladders, aerial lifts, respirators, safety glasses, face shields, shade lenses, etc. This does not include hard hats and steel-toed safety boots.

\subsection{ENVIRONMENTAL PROTECTION}

The environmental resources within the project boundaries and those affected outside the limits of permanent work under this contract shall be protected during the entire period of this contract. 


\subsubsection{Desert Tortoise Protection}

The Desert Tortoise is a federally endangered species, and the Contractor shall ensure that they are protected throughout the project site. The superintendent and all contract employees involved in earthwork operations shall view a NASA training film about the Desert Tortoise, approximately 1 hour long. The Contractor shall take extreme care to protect the Desert Tortoise when in the clean soil disposal site.

\subsubsection{Cultural Resource Protection}

In the event cultural or historical materials are found during the performance of this contract, work will cease immediately in the find area and the Contracting Officer shall be notified accordingly.

\subsubsection{Air Quality}

The Contractor's operations shall satisfy air quality requirements for Kern County Air Pollution Control District.

\subsubsection{Water Quality}

The Contractor's operations shall satisfy water quality requirements for the Lahontan Regional Water Quality Control Board.

\subsection{DUST CONTROL}

The Contractor shall maintain excavations, embankments, stockpiles, temporary roads, plant sites, waste areas, borrow areas, and other work areas within or beyond the project site free from dust which would cause a hazard or nuisance to others. Methods of stabilization consisting of water sprinkling, chemical treatment, light bituminous treatment or similar methods will be permitted to control dust. Sprinkling shall be repeated at such intervals as to keep the disturbed area damp at all times. Dust control shall be performed as the work proceeds and whenever a nuisance or hazard occurs.

When the jobsite is inside an occupied building, the Contractor shall provide and install dust barriers to control dust movement so that dirt and dust does not migrate out of the construction site and into occupied sections of the building. Any corridors, offices, and other rooms that become contaminated by dirt and dust migrating from the Contractor's activity shall be cleaned, dusted, and vacuumed by the Contractor at no expense to the Government.

\section{$\underline{1.20}$ FIRST AID AND EMERGENCIES}

Contractor personnel who sustain injury or become ill, on-site during normal duty hours, may be examined and/or given first aid treatment at the NASA/DFRC Dispensary in Building 4822, telephone (661) 276-3258 or (661) 276-3570. Outside normal duty hours the Contractor is responsible for first aid treatment of employees and transportation to a medical facility off-site. 
All injuries sustained on-site must be reported to the Contracting Officer whether treated at the NASA/DFRC facility or elsewhere. (Normal duty hours are defined in Section 01010 "Standard Requirements" Paragraph 1.8 "NORMAL DUTY HOURS".)

Emergency telephone numbers and reporting instructions shall be conspicuously posted at the job site. Fire, rescue, and first aid are available by contacting 911 on a NASA/DFRC telephone. If a NASA/DFRC phone is not available in an emergency, call Security post 1 at (661) 276-3256 and clearly explain the emergency. A direct 911 contact cannot be made by use of a personal or cellular phone. To summarize, in an emergency from a:
a. NASA/DFRC phone
dial
911
b. Personal or Cellular phone
dial
(661) 276-3256

$\underline{\text { PART } 2 \text { PRODUCTS (Not Applicable) }}$

PART 3 EXECUTION (Not Applicable)

END OF SECTION 01411 


\section{$\underline{\text { SECTION 01420-SOURCES FOR REFERENCE PUBLICATIONS }}$}

\section{PART 1 - GENERAL}

\subsection{REFERENCES}

Reference publications are cited in other sections of the specifications along with identification of their sponsoring organizations. The addresses of the sponsoring organizations are listed below, and if the source of the publications is different from the address of the sponsoring organization, that information is also provided.

AMERICAN CONCRETE INSTITUTE (ACI)

P.O. Box 9094

Farmington Hills, MI 48333-9094

Ph: 248-848-3700

Fax: 248-848-3701

Internet: http://www.aci-int.inter.net

AMERICAN ARCHITECTURAL MANUFACTURERS ASSOCIATION (AAMA)

1827 Walden Ofc. Sq.

Suite 104

Schaumburg, IL 60173-4268

Ph: 847-303-5664

Fax: 847-303-5774

Internet: www.aamanet.org

AMERICAN ASSOCIATION OF STATE HIGHWAY AND TRANSPORTATION OFFICIALS (AASHTO)

444 N. Capital St., NW, Suite 249

Washington, DC 20001

Ph: $800-231-3475$ or $202-624-5800$

Fax: 800-525-5562 or 202-624-5806

Internet: www.aashto.org

AMERICAN BEARING MANUFACTURERS ASSOCIATION (ABMA)

1101 Connecticut Ave., NW, Suite 300

Washington, DC 20036-2422

$\mathrm{Ph}: 202-429-5155$

Fax: 202-828-6042 
AMERICAN INSTITUTE OF STEEL CONSTRUCTION (AISC)

One East Wacker Dr., Suite 3100

Chicago, IL 60601-2001

$\mathrm{Ph}: 312-670-2400$

Publications: 800-644-2400

Fax: 312-670-2400

Internet: http://www.aiscweb.com

AMERICAN INSTITUTE OF TIMBER CONSTRUCTION (AITC)

7012 So. Revere Parkway, Suite 140

Englewood, CO 80112

$\mathrm{Ph}: 303-792-9559$

Fax: 303-792-0669

AMERICAN IRON AND STEEL INSTITUTE (AISI)

ATTN: Publication Orders

P.O. Box 4321

Chestertown, MD 21690

$\mathrm{Ph}: 800-277-3850$

Fax: 410-810-0910

AMERICAN NATIONAL STANDARDS INSTITUTE (ANSI)

11 West 42nd St

New York, NY 10036

$\mathrm{Ph}: 212-642-4900$

Fax: 212-302-1286

Internet: http://www.ansi.org/

AMERICAN SOCIETY FOR NONDESTRUCTIVE TESTING (ASNT)

1711 Arlingate Lane

P.O. Box 28518

Columbus, OH 43228-0518

Ph: 800-222-2768

Fax: 614-274-6899 
AMERICAN SOCIETY FOR TESTING AND MATERIALS (ASTM)

100 Barr Harbor Drive

West Conshohocken, PA 19428-2959

Ph: 610-832-9500

Fax: 610-832-9555

Internet: www.astm.org

AMERICAN SOCIETY OF CIVIL ENGINEERS (ASCE)

1801 Alexander Bell Drive

Reston, VA 20190-4400

Ph: 703-295-6300

Fax: 703-295-6222

Internet: www.pubs.asce.org

e-mail: marketing@asce.org

AMERICAN SOCIETY OF MECHANICAL ENGINEERS (ASME)

Three Park Avenue

New York, NY 10016-5990

$\mathrm{Ph}: 212-591-7722$

Fax: 212-591-7674

Internet: www.asme.org

AMERICAN WELDING SOCIETY (AWS)

550 N.W. LeJeune Road

Miami, FL 33126

Ph: 800-443-9353

Fax: 305-443-7559

Internet: www.amweld.org

AMERICAN WOOD-PRESERVERS' ASSOCIATION (AWPA)

3246 Fall Creek Highway, Suite 1900

Grandbury, TX 76049-7979

Ph: 817-326-6300

Fax: 817-326-6306 


\section{AMERICAN SOCIETY FOR METALS (ASM)}

Materials Park, OH 44073-0002

$\mathrm{Ph}:$ 216-338-5151

Order Publications From:

ASM International

ATTN: MSC/Book Order

P.O. Box 473

Novelty, OH 44072-9901

ASPHALT INSTITUTE (AI)

Research Park Dr.

P.O. Box 14052

Lexington, KY 40512-4052

Ph: 606-288-4960

Fax: 606-288-4999

Internet: www.asphaltinstitute.org

e-mail: asphalti@asphaltinstitute.org

BUILDING OFFICIALS \& CODE ADMINISTRATORS (BOCA)

4051 W. Flossmoor Rd.

Country Club Hills, IL 60478

Ph: 708-799-2300

Fax: 708-799-4981

E-mail: boca@aecnet.com

\section{BUREAU OF RECLAMATION (BOR)}

Dept. of the Interior

P.O. Box 25007

Denver, CO 80225

$\mathrm{Ph}:$ 303-236-0305, ext. 457

Order from:

National Technical Information

Services (NTIS)

5285 Port Royal Rd.

Springfield, VA 22161

Ph: 703-605-6000

Fax: 703-605-6900

Internet: http://www.fedworld.gov/ntis/ntishome.html 


\section{CALIFORNIA REDWOOD ASSOCIATION (CRA)}

405 Enfrente Ave., Suite 200

Novato, CA 94949

Ph: 415-382-0662

Fax: 415-382-8531

\section{CALIFORNIA DEPARTMENT OF TRANSPORTATION (CDT)}

Publication Distributiopn Unit

1900 Royal Oaks Dr.

Sacramento, CA 95815

Ph: 800-553-3520 or 916-227-7000 (CA Transportation Lab)

Fax: 916-324-8997

CODE OF FEDERAL REGULATIONS (CFR)

Order from:

Government Printing Office

Washington, DC 20402

Ph: 202-512-1800

Fax: 202-275-7703

Internet: http://www.pls.com:8001/his/cfr.html

COMMERCIAL ITEM DESCRIPTIONS (CID)

Order from:

General Services Administration

Federal Supply Service Bureau

470 E L'Enfant Plaza, S.W.

Washington, DC 20407

Ph: 202-619-8925

Internet: http://pub.fss.gsa.gov/h1-pub.html

CONCRETE REINFORCING STEEL INSTITUTE (CRSI)

933 No. Plum Grove Rd.

Schaumburg, IL 60173-4758

Ph: 847-517-1200

Fax: 847-517-1206

Internet: http://www.crsi.org 


\section{CONSUMER PRODUCT SAFETY COMMISSION (CPSC)}

Washington, DC 20207

Ph: 301-504-0580

COPPER DEVELOPMENT ASSOCIATION (CDA)

260 Madison Ave.

New York, NY 10016

Ph: 212-251-7200

Fax: 212-251-7234

E-mail: http://www.copper.org

CORPS OF ENGINEERS (COE)

Order from:

U.S. Army Engineer Waterways Experiment Station

ATTN: Technical Report Distribution Section

Services Branch, TIC

3909 Halls Ferry Rd.

Vicksburg, MS 39180-6199

Ph: 601-634-2571

Fax: 601-634-2506

COUNCIL OF AMERICAN BUILDING OFFICIALS (CABO)

5203 Leesburg Pike, Suite 708

Falls Church, VA 22041

$\mathrm{Ph}:$ 703-931-4533

Fax: 703-379-1546

ELECTRONIC INDUSTRIES ASSOCIATION (EIA)

2500 Wilson Blvd.

Arlington, VA 22201-3834

Ph: 703-907-7500

Fax: 703-907-7501

Internet: www.eia.org

ENGINEERING MANUALS (EM)

USACE Publications Depot

ATTN: CEIM-SP-D

2803 52nd Avenue

Hyattsville, MD 20781-1102

Ph: 301-394-0081 


\section{ENGINEERING PAMPHLETS (EP)}

USACE Publications Depot

ATTN: CEIM-SP-D

2803 52nd Avenue

Hyattsville, MD 20781-1102

Ph: 301-394-0081

\section{ENGINEERING REGULATIONS (ER)}

USACE Publications Depot

ATTN: CEIM-SP-D 2803 52nd Avenue

Hyattsville, MD 20781-1102

Ph: 301-394-0081

FACTORY MUTUAL ENGINEERING AND RESEARCH (FM)

1151 Boston-Providence Turnpike

P.O. Box 9102

Norwood, MA 02062-9102

Ph: 617-255-4681

Fax: 617-255-4359

Internet: http://www.factorymutual.com

FEDERAL AVIATION ADMINISTRATION (FAA)

Order from:

Superintendent of Documents

U. S. Government Printing Office

Washington, DC 20402

Ph: 202-512-1800

Fax: 202-512-1356

For free documents, order from:

Federal Aviation Administration

Dept. of Transportation

ATTN: General Services Section M-45

400 Seventh St., SW

Washington, DC 20590-0001

Ph: 202-619-8925

Fax: 202-619-8978 


\section{FEDERAL SPECIFICATIONS (FS)}

Order from:

General Services Administration

Federal Supply Service Bureau

470 L'Enfant Plaza, S.W.

Washington, DC 20407

Ph: 202-619-8925

Fax: 202-619-8978

Internet: http://pub.fss.gsa.gov/h1-pub.html

FEDERAL STANDARDS (FED-STD)

Order from:

General Services Administration

Federal Supply Service Bureau

470 E L'Enfant Plaza, S.W.

Washington, DC 20407

Ph: 202-619-8925

Fax: 202-619-8978

Internet: http://pub.fss.gsa.gov/hi-pub.html

GEOLOGICAL SOCIETY OF AMERICA (GSA)

P.O. Box 9140

Boulder, CO 80301

Ph: 800-472-1988

Fax: 303-447-1133

INSTITUTE FOR INTERCONNECTING AND PACKAGING ELECTRONIC CIRCUITS (IPC)

2215 Sanders Rd.

Northbrook, IL 60062-6135

Ph: 847-509-9700

Fax: 847-509-9798

Internet: www.ipc.org

e-mail: orderipc@ipc.org 
INSTITUTE OF ELECTRICAL AND ELECTRONICS ENGINEERS (IEEE)

445 Hoes Ln, P. O. Box 1331

Piscataway, NJ 08855-1331

Ph: 732-981-0060 OR 800-701-4333

Fax: 732-981-9667

Internet: http//www.standards.ieee.org

E-mail: customer.service@ieee.org

INSTITUTE OF ENVIRONMENTAL SCIENCES (IES)

940 East Northwest Highway

Mount Prospect, IL 60056

$\mathrm{Ph}: 847-255-1561$

Fax: 847-255-1699

INSULATED CABLE ENGINEERS ASSOCIATION (ICEA)

P.O. Box 440

South Yarmouth, MA 02664

$\mathrm{Ph}: 508-394-4424$

Fax: 508-394-1194

E-mail: www.electricnet.com/orgs/insucbl.htm

INTERNATIONAL ELECTROTECHNICAL COMMISSION (IEC)

3 , rue de Varembe, Case Postale 131

CH-1211 Geneva 20, Switzerland

$\mathrm{Ph}:$ 41-22-919-0211

Fax: 41-22-919-0300

Internet: http://www.iec.ch

e-mail: custserv@iec.ch

INTERNATIONAL ORGANIZATION FOR STANDARDIZATION (ISO))

1, rue de Varembe'

Case Postale 56

CH-1211 Geneve 20

Switzerland

Internet: www.iso.ch 


\section{IRON AND STEEL SOCIETY (ISS)}

186 Thornhill Road

Warrendale, PA 15086-7528

Ph: 412-776-1353, ext. 1

Fax: 412-776-0430

E-Mail: custserv@issource.org

Internet: www.issourse.org

INSTRUMENT SOCIETY OF AMERICA (ISA)

67 Alexander Drive

P.O. Box 12277

Research Triangle Park, NC 27709

Ph: 919-549-8411

Fax: 919-549-8288

e-mail: ISA@isa.org

Internet: http://www.isa.org

JOHN F. KENNEDY SPACE CENTER (KSC)

KSC Doc Library - D

Kennedy Space Center, FL 32899

Ph: 407-867-3613

\section{KENNEDY SPACE CENTER HANDBOOK (KHB)}

NASA

KSC Pollution Control and Sanitation Officer

MD-MED-P

Kennedy Space Center, FL 32899

MILITARY HANDBOOKS (MIL-HDBK)

Order from:

Standardization Documents Order Desk

Bldg 4D

700 Robbins AV

Philadelphia, PA 19111-5094

Ph: 215-697-5147

Fax: 215-697-5148

Internet: www.dodssp.daps.mil 


\section{MILITARY SPECIFICATIONS (MS)}

Order from:

Standardization Documents Order Desk

Building 4, Section D

700 Robbins Ave.

Philadelphia, PA 19111-5094

Ph: 215-697-5147

Fax: 215-697-5148

Internet: www.dodssp.daps.mil

MILITARY STANDARDS (MIL-STD)

Order from:

Standardization Documents Order Desk

Building 4, Section D

700 Robbins Ave.

Philadelphia, PA 19111-5094

Ph: 215-697-2179

Fax: 215-697-2978

Internet: www.dodssp.daps.mil

NATIONAL AERONAUTICS AND SPACE ADMINISTRATION (NASA)

Publication(s) Available From

Superintendent of Documents

U.S. Government Printing Office

Washington, DC 20402

Ph: 202-783-3238

NATIONAL ASSOCIATION OF CORROSION ENGINEERS (NACE)

1440 South Creek Drive

Houston, TX 77084-4906

Ph: 221-228-6200

Fax: 281-228-6300

Internet: www.nace.org

NATIONAL ELECTRICAL MANUFACTURERS ASSOCIATION (NEMA)

1300 N. 17th St., Suite 1847

Rosslyn, VA 22209

$\mathrm{Ph}: 703-841-3200$

Fax: 202-841-3300

Internet: http//www.nema.org/ 


\section{NATIONAL FIRE PROTECTION ASSOCIATION (NFPA)}

One Batterymarch Park

P.O. Box 9101

Quincy, MA 02269-9101

Ph: 800-344-3555

Fax: 800-593-6372

Internet: http://www.nfpa.org

NATIONAL FOREST PRODUCTS ASSOCIATION (NFOPA)

1250 Connecticut Ave., NW, Suite 200

Washington, DC 20036

$\mathrm{Ph}: 202-463-2766$

Fax: 202-463-2791

NATIONAL HARDWOOD LUMBER ASSOCIATION (NHLA)

P.O. Box 34518

Memphis, TN 38184-0518

$\mathrm{Ph}: 901-377-1818$

Fax: 901-382-6419

e-mail:nhla@natlhardwood.org

NATIONAL INSTITUTE FOR CERTIFICATION IN ENGINEERING TECHNOLOGIES (NICET)

1420 King Street

Alexandria, VA 22314-2794

$\mathrm{Ph}: 888-476-4238$

Internet: www.nicet.org

NATIONAL INSTITUTE FOR STANDARDS AND TECHNOLOGY (NIST)

Department of Commerce

Gaithersburg, MD 20899-0001

$\mathrm{Ph}: 301-975-4025$

Fax: 301-926-1630

Order From:

Superintendent of Documents

U.S. Government Printing Office (GPO)

Washington, DC 20402

$\mathrm{Ph}: 202-512-1800$

Fax: 202-512-2250

or 
National Technical Information Services (NTIS)

5285 Port Royal Rd.

Springfield, VA 22161

$\mathrm{Ph}: 800-553-6847$

Fax: 703-321-8547

Internet: http://ww.gov/ntis.gov

NATIONAL LIME ASSOCIATION (NLA)

200 No. Glebe Rd., Suite 800

Arlington, VA 22203-3728

$\mathrm{Ph}: 703-243-5463$

Fax: 703-243-5489

NATIONAL READY-MIXED CONCRETE ASSOCIATION (NRMCA)

900 Spring St.

Silver Spring, MD 20910

$\mathrm{Ph}: 301-587-1400$

Fax: 301-585-4219

NAVAL FACILITIES ENGINEERING COMMAND (NAVFAC)

1510 Gilbert St.

Norfolk, VA 23511-2699

$\mathrm{Ph}: 757-322-4200$

Fax: $757-322-4416$

NAVAL FACILITIES ENGINEERING SERVICE CENTER (NFESC)

560 Center Drive

Port Hueneme, CA 93043-4328

$\mathrm{Ph}: 805-982-5661$

NORTHEASTERN LUMBER MANUFACTURERS ASSOCIATION (NELMA)

272 Tuttle Road

Cumberland Center, ME 04021

$\mathrm{Ph}: 207-829-6901$

Fax: 207-829-4293 
Cooperative Extension

152 Riley-Robb Hall

Ithaca, NY 14853-5701

$\mathrm{Ph}: 607-255-7654$

Fax: 607-254-8770

Internet: http://rcwpsun.cas.psu.edu/nraes

E-mail: nraes@cornell.edu

PLASTIC PIPE AND FITTINGS ASSOCIATION (PPFA)

800 Roosevelt Rd., Bldg C, Suite 20

Glen Ellyn, IL 60137

$\mathrm{Ph}: 630-858-6540$

Fax: 630-790-3095

PLASTICS PIPE INSTITUTE (PPI)

1801 L St. NW, Suite 600K

Washington, D. C. 20006-1301

$\mathrm{Ph}: 888-314-6774$

Fax: 202-293-0048

Internet: http://www.plasticpipe.org

Order Publications from:

SPI

P. O. Box 753

Waldorf, MD 20604

$\mathrm{Ph}: 202-974-5332$

Fax: 800-541-0736 or 202-296-7359

PRESTRESSED CONCRETE INSTITUTE (PCI)

175 West Jackson Blvd., Suite 1859

Chicago, IL 60604

$\mathrm{Ph}: 312-786-0300$

Fax: 312-786-0353

Internet: www.pci.org

e-mail: info@pci.org

REDWOOD INSPECTION SERVICE (RIS)

591 Redwood Highway, Suite 3100

Mill Valley, CA 94941 


\section{RUBBER MANUFACTURERS ASSOCIATION (RMA)}

1400 K St., NW

Washington, DC 20005

$\mathrm{Ph}: 202-682-4800$

Fax: 202-682-4854

Order Publications from:

The Mail Room

P. O. Box 3147

Medina, $\mathrm{OH} 44258$

Ph: $800-325-5098$ or $330-723-2987$

Fax: $330-725-0576$

\section{RURAL ELECTRIFICATION ADMINISTRATION (REA)}

Order from:

USDA-REA-ASD

ATTN: Publications

14th and Independence Ave., SW, Room 0180

Washington, DC 20250

$\mathrm{Ph}: 202-720-8674$

RURAL UTILITIES SERVICE (RUS)

ATTN: Publications

14th and Independence Ave., SW, Room 4028-S

Washington, DC 20250

$\mathrm{Ph}: 202-720-8674$

Fax: 202-205-3654

Internet: www.usda.gov/rus

SOUTHERN CYPRESS MANUFACTURERS ASSOCIATION (SCMA)

400 Penn Center Boulevard, Suite 530

Pittsburgh, PA 15235

$\mathrm{Ph}: 412-829-0770$

Fax: 412-829-0844

SOUTHERN PINE INSPECTION BUREAU (SPIB)

4709 Scenic Highway

Pensacola, FL 32504-9094

$\mathrm{Ph}: 850-434-2611$

Fax: 850-433-5594

e-mail: spib@spib.org 


\section{U.S. AIR FORCE TECHNICAL ORDERS (TO)}

Air Force Logistics Command, ATTN: D.A.D.

Wright-Patterson Air Force Base, OH 45433

U.S. DEPARTMENT OF TRANSPORTATION (USDT)

Superintendent of Documents

U.S. Government Printing Office

Washington, DC 20402

UNDERWRITERS LABORATORIES (UL)

333 Pfingsten Rd.

Northbrook, IL 60062-2096

$\mathrm{Ph}: 847-272-8800$

Fax: 847-272-8129

Internet: http://www.ul.com/

Order from:

Global Engineering Documents

15 Inverness Way East

Englewood, CO 80112-5776

$\mathrm{Ph}: 800-569-7128$

Fax: 303-397-7945

Internet: http://global.ihs.com

E-mail: global@ihs.com

UNI-BELL PVC PIPE ASSOCIATION (UBPPA)

2655 Villa Creek Dr., Suite 155

Dallas, TX 75234

$\mathrm{Ph}: 214-243-3902$

Fax: 214-243-3907

\section{U.S. ARMY ENVIORNMENTAL HYGIENE AGENCY (USAEHA)}

Waste Disposal Engineering Division

Aberdeen Proving Ground, MD 21010-5422

$\mathrm{Ph}: 410-671-3652$ 


\section{U.S. GENERAL SERVICES ADMINISTRATION (GSA)}

Order from:

General Services Administration

Federal Supply Service Bureau

470 E L'Enfant Plaza, S.W., Suite 8100

Washington, DC 20407

$\mathrm{Ph}: 202-619-8925$

Fax: 202-619-8978

Internet: fss.gsa.gov/pub/fed-specs.cfm

AOK 5/01

LOK $6 / 00$

WEST COAST LUMBER INSPECTION BUREAU (WCLIB)

P.O. Box 23145

Portland, OR 97281

$\mathrm{Ph}: 503-639-0651$

Fax: 503-684-8928

WESTERN WOOD PRESERVERS INSTITUTE (WWPI)

7017 N.E. Highway 99 \# 108

Vancouver, WA 98666

$\mathrm{Ph}: 360-693-9958$

Fax: 360-693-9967

WESTERN WOOD PRODUCTS ASSOCIATION (WWPA)

Yeon Bldg. 522 SW 5th Ave.

Portland, OR 97204-2122

$\mathrm{Ph}: 503-224-3930$

Fax: 503-224-3934

\section{END OF SECTION 01420}




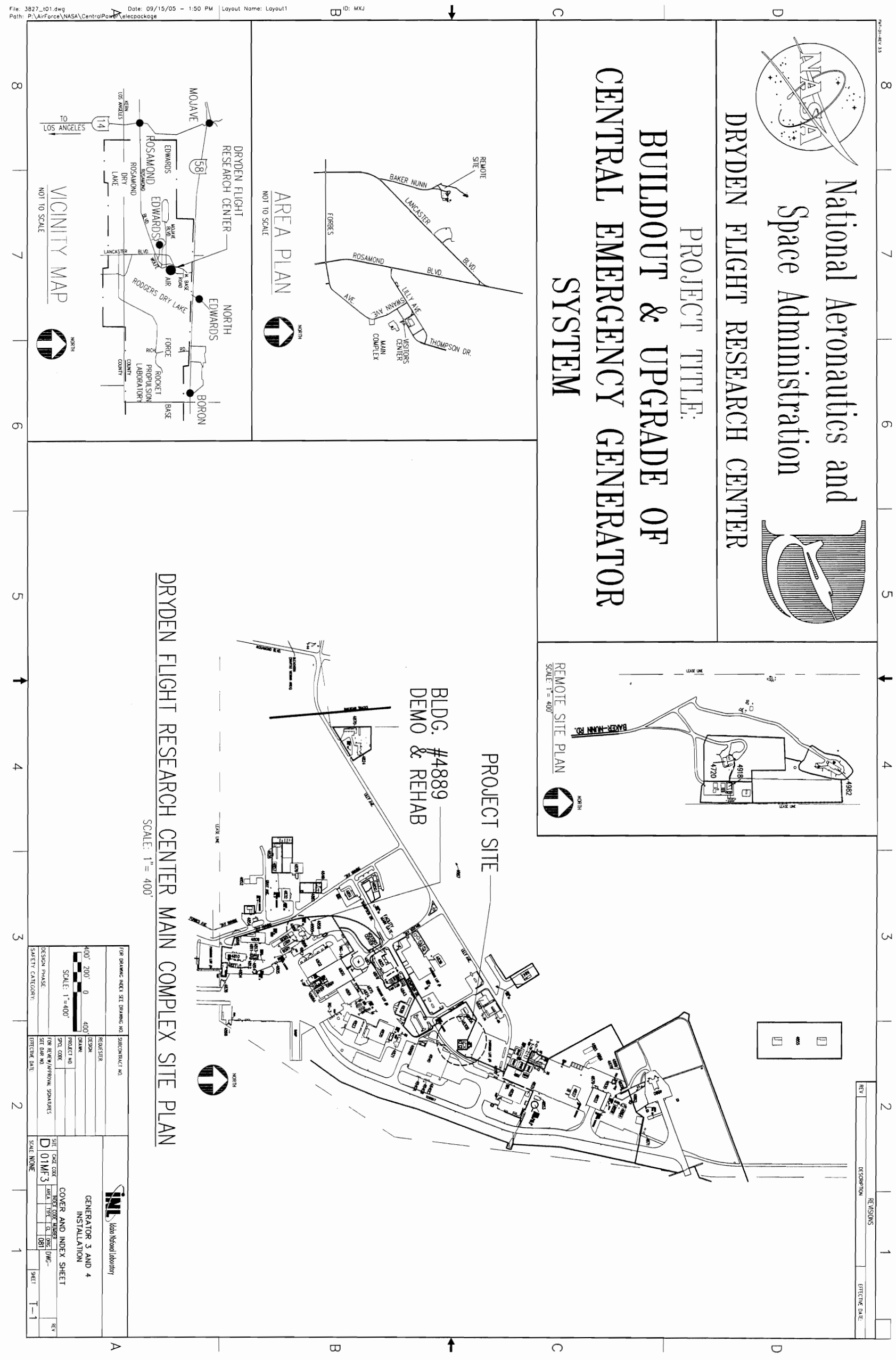




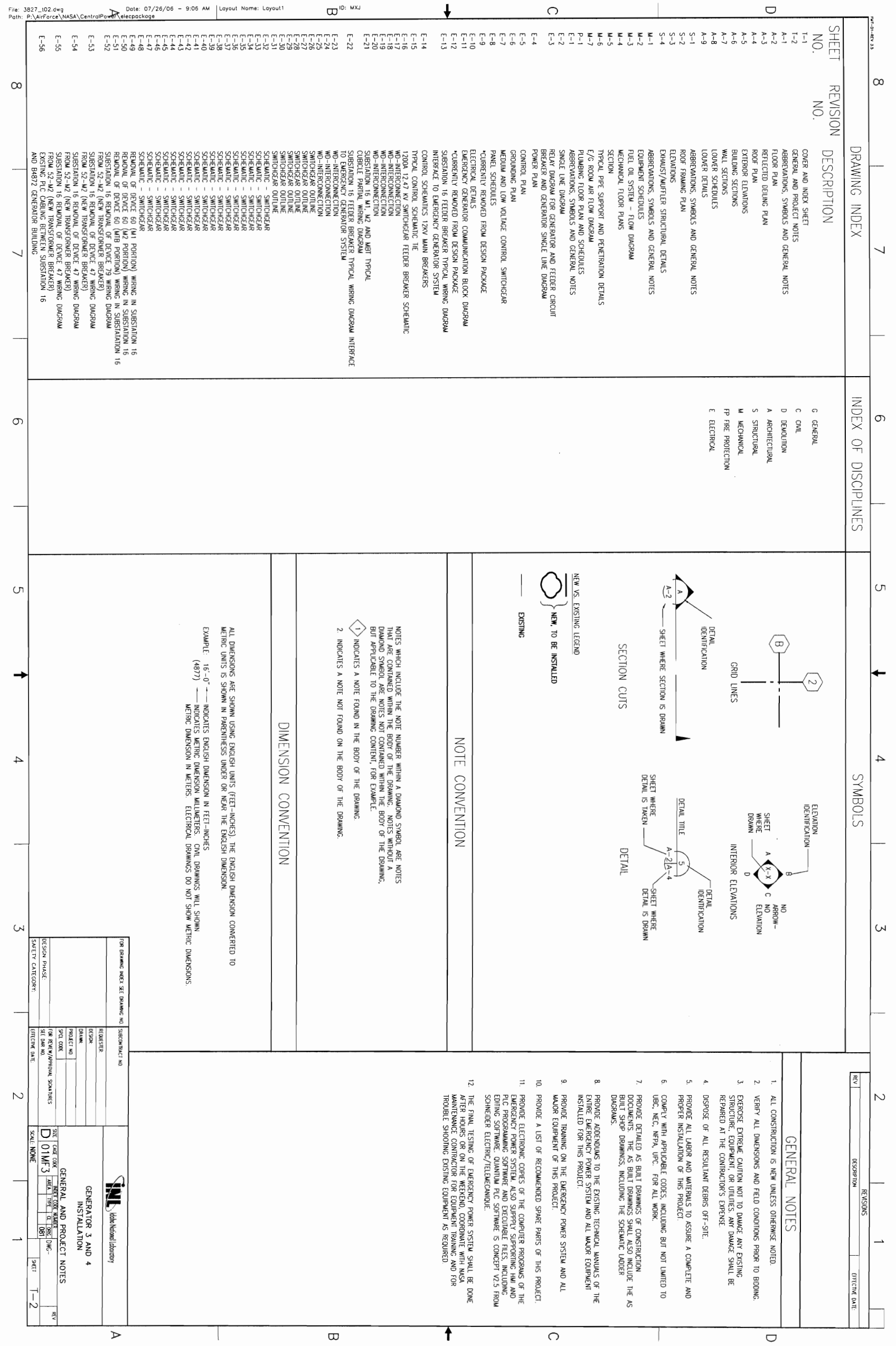




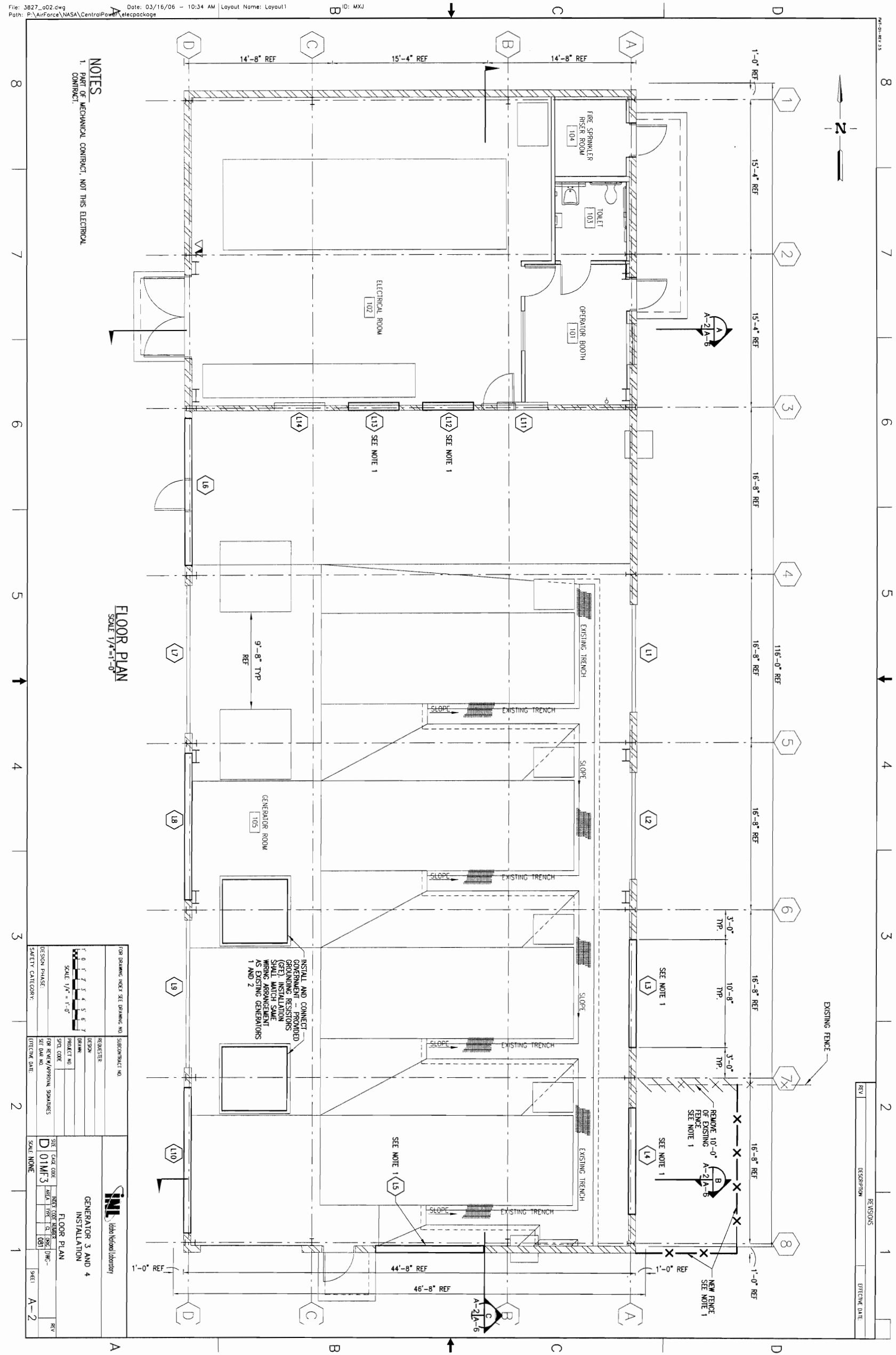




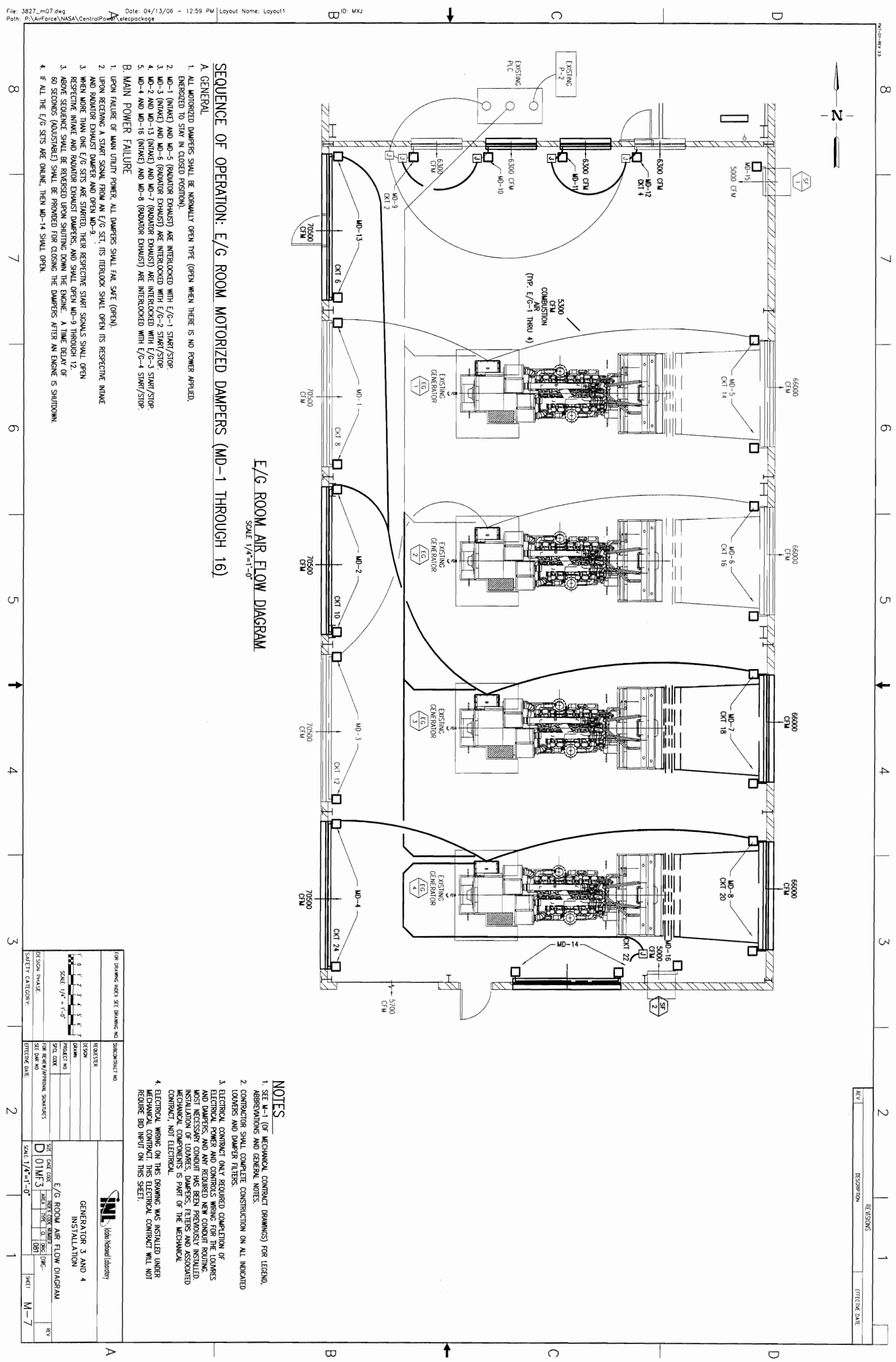




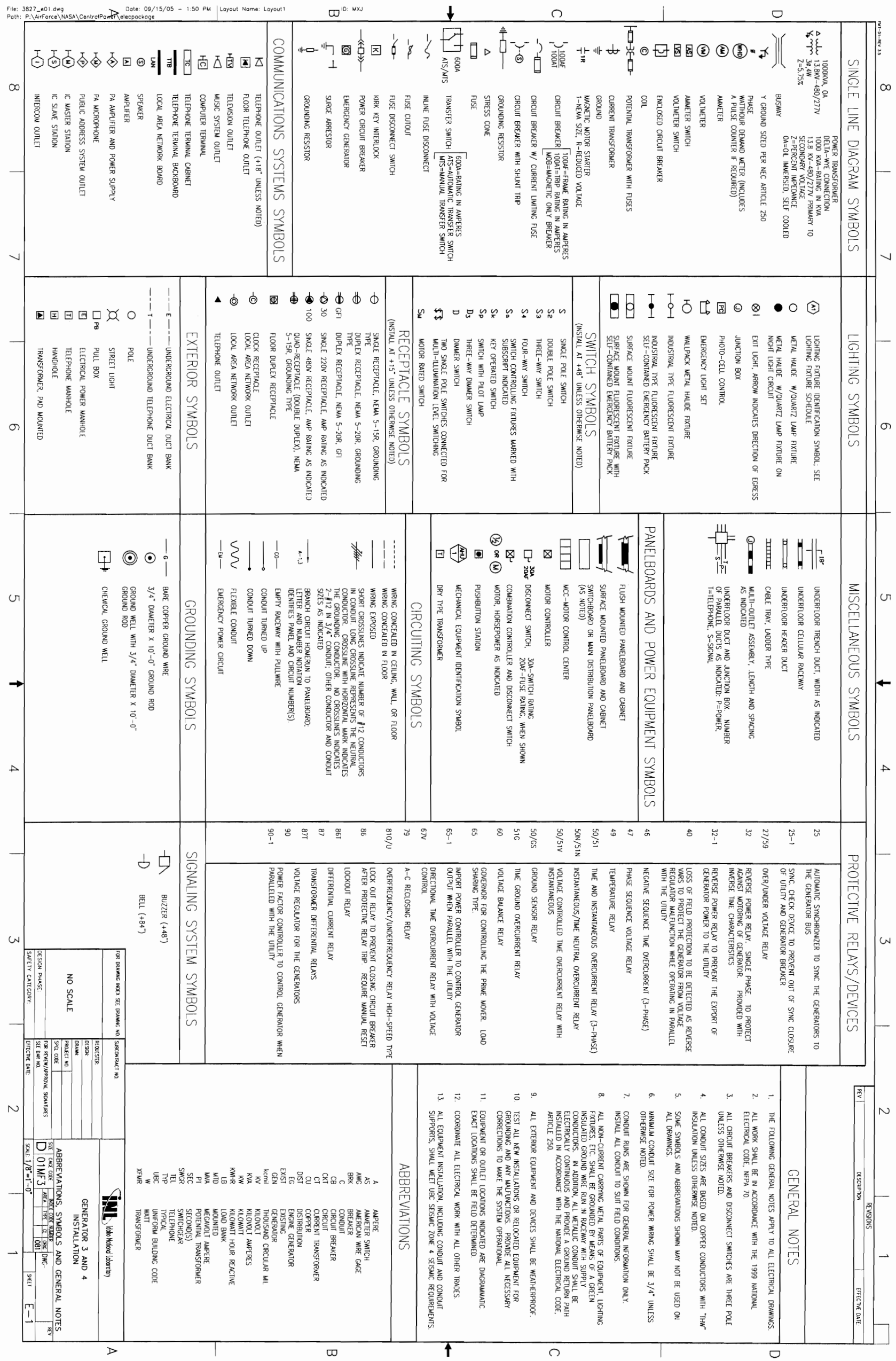




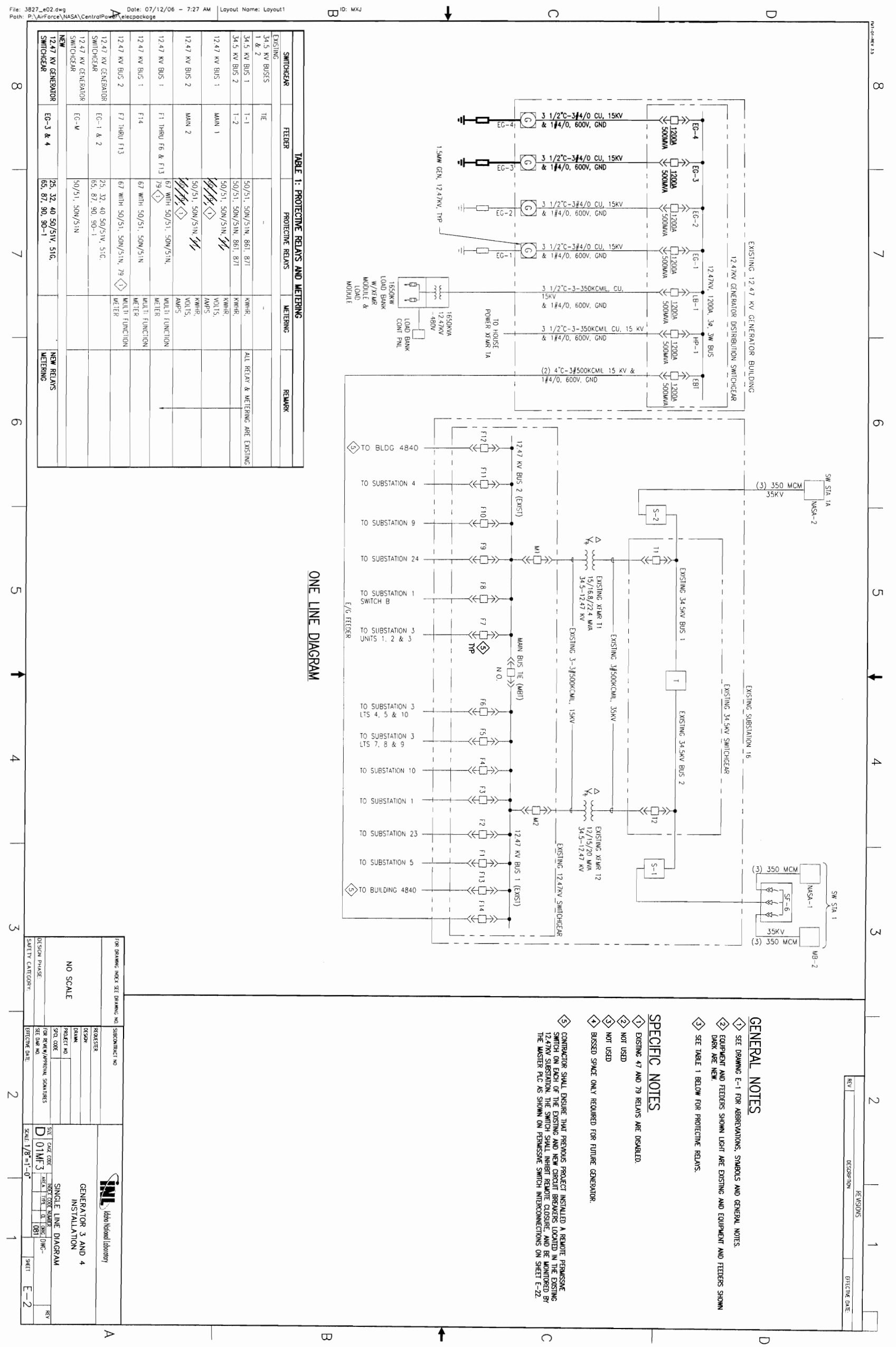




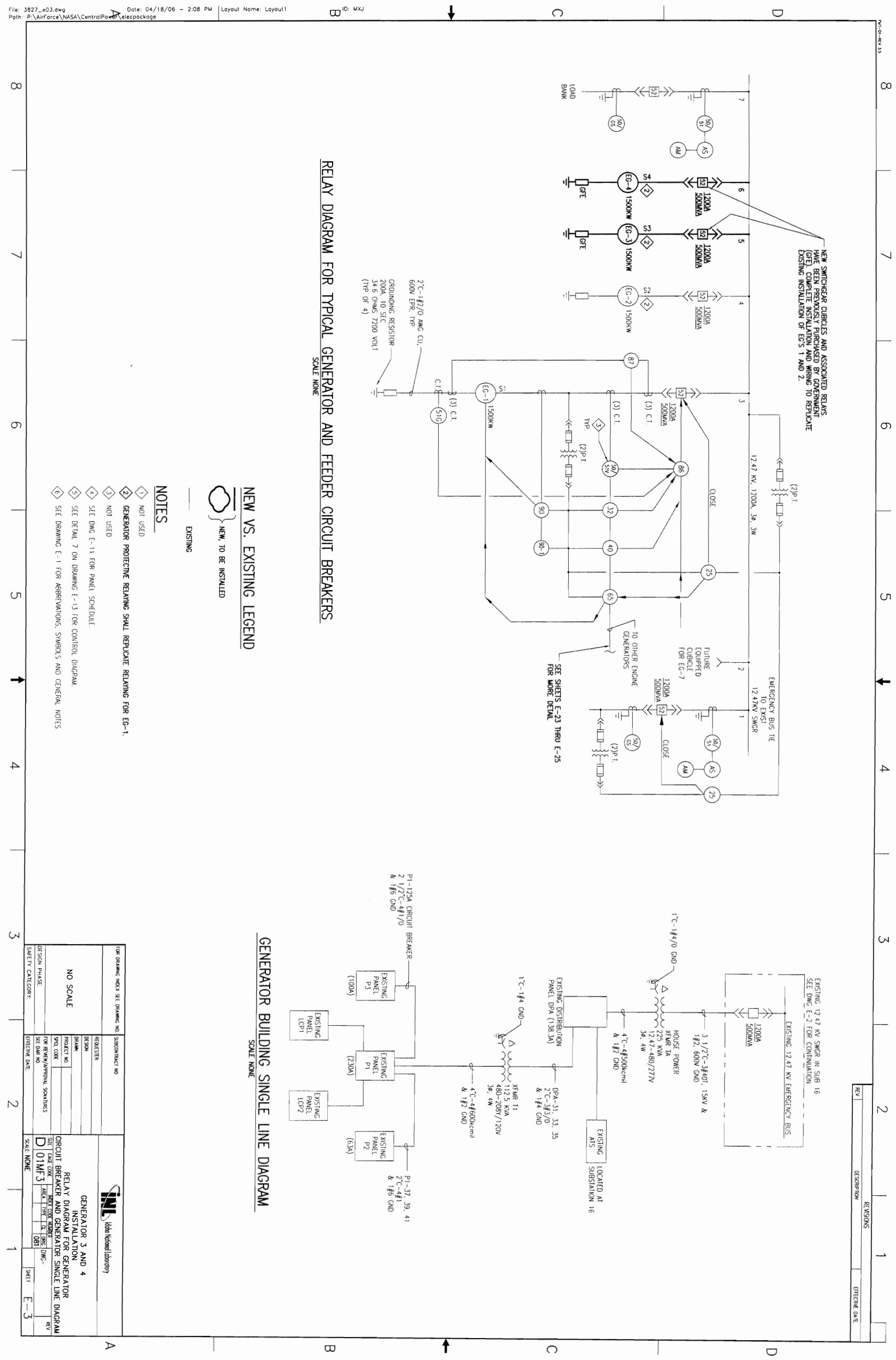




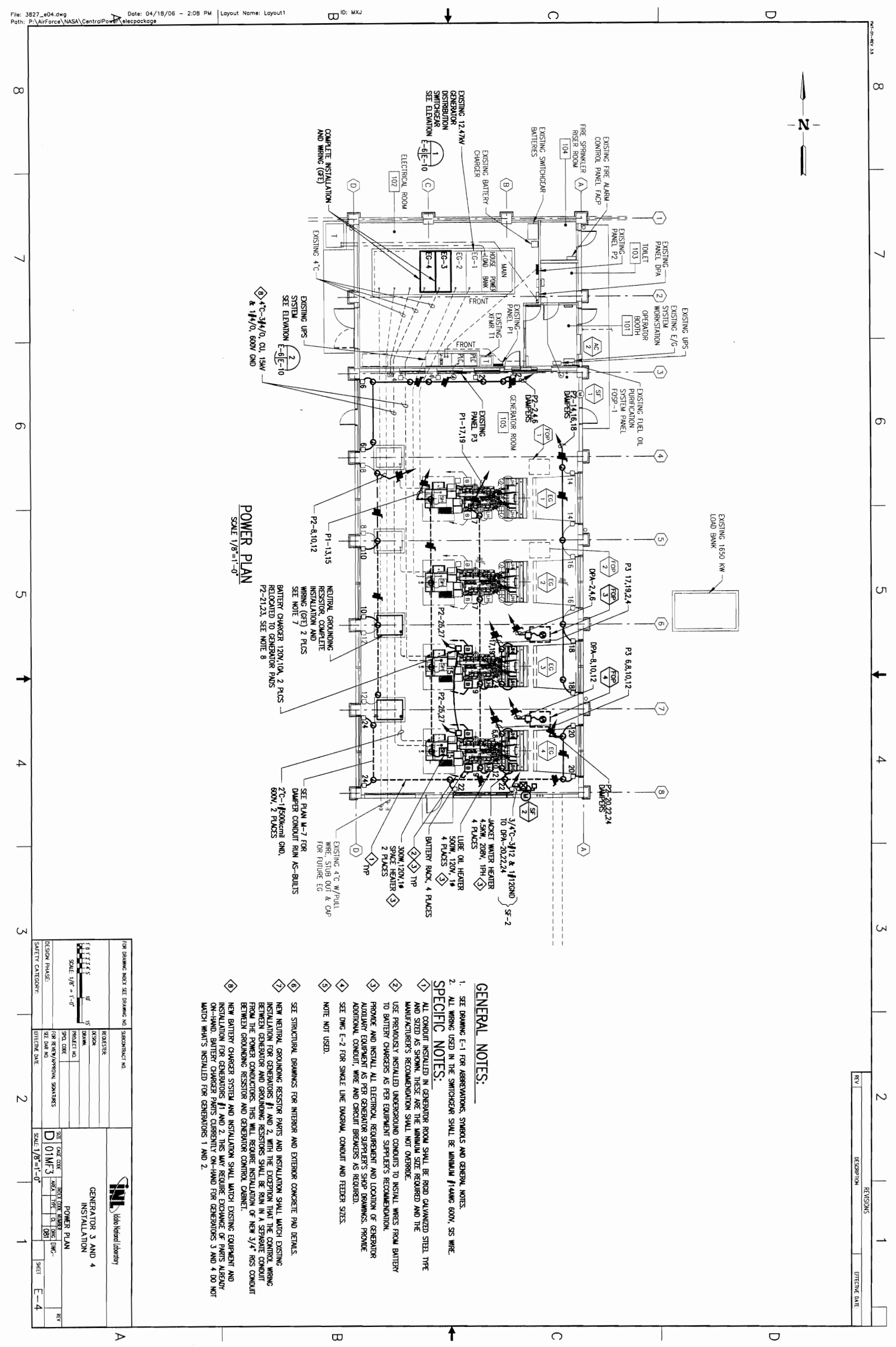




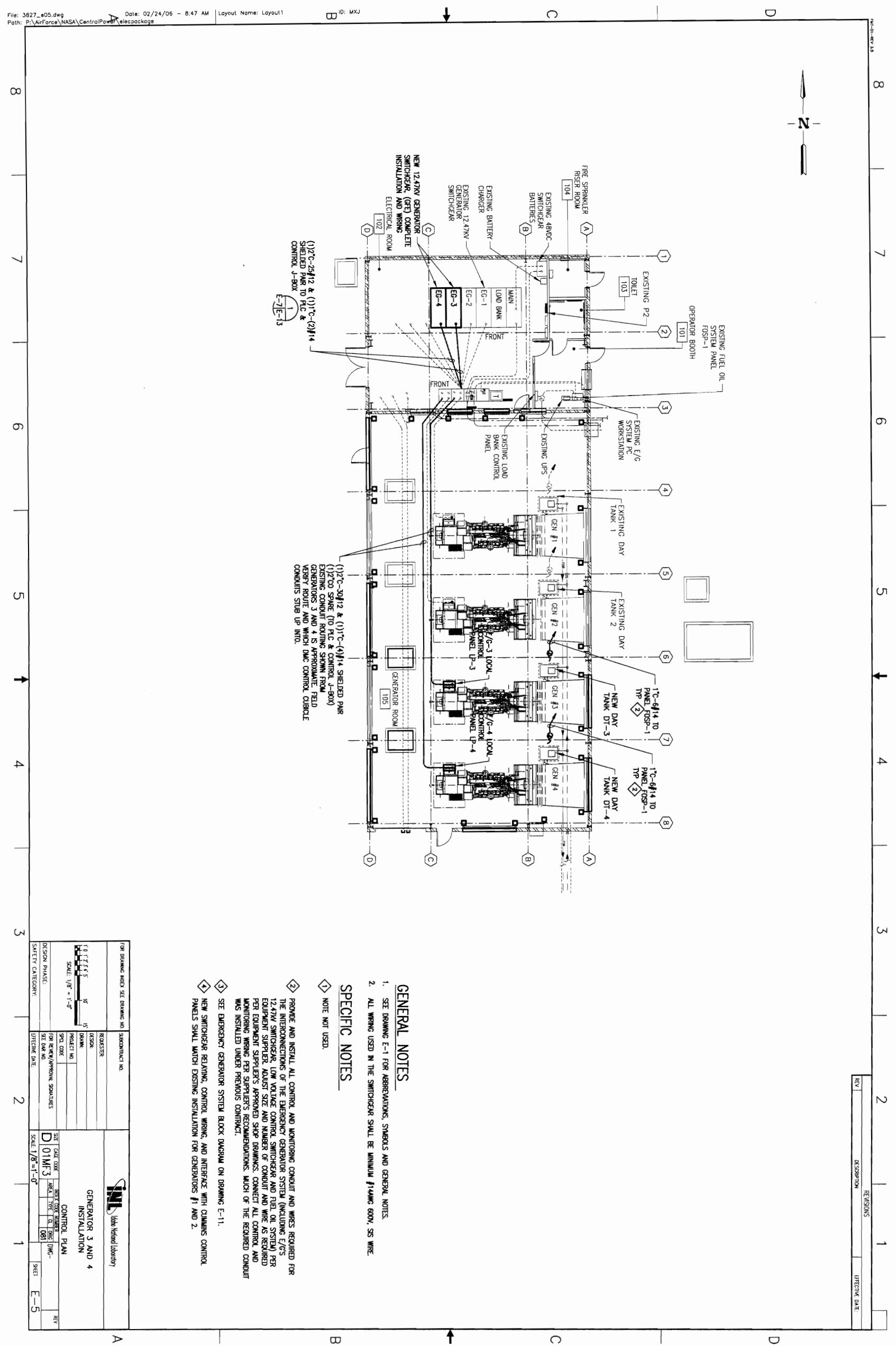




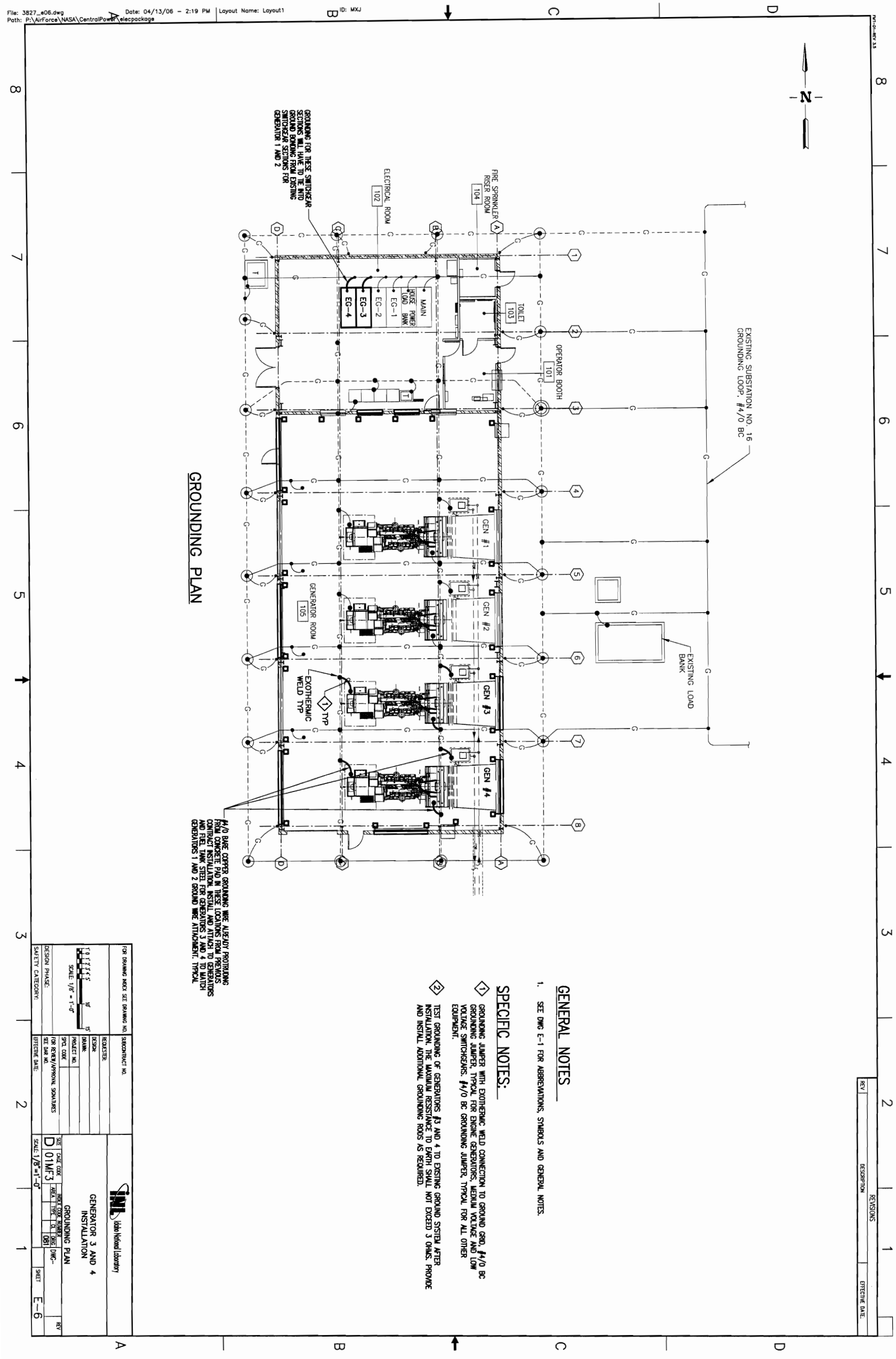




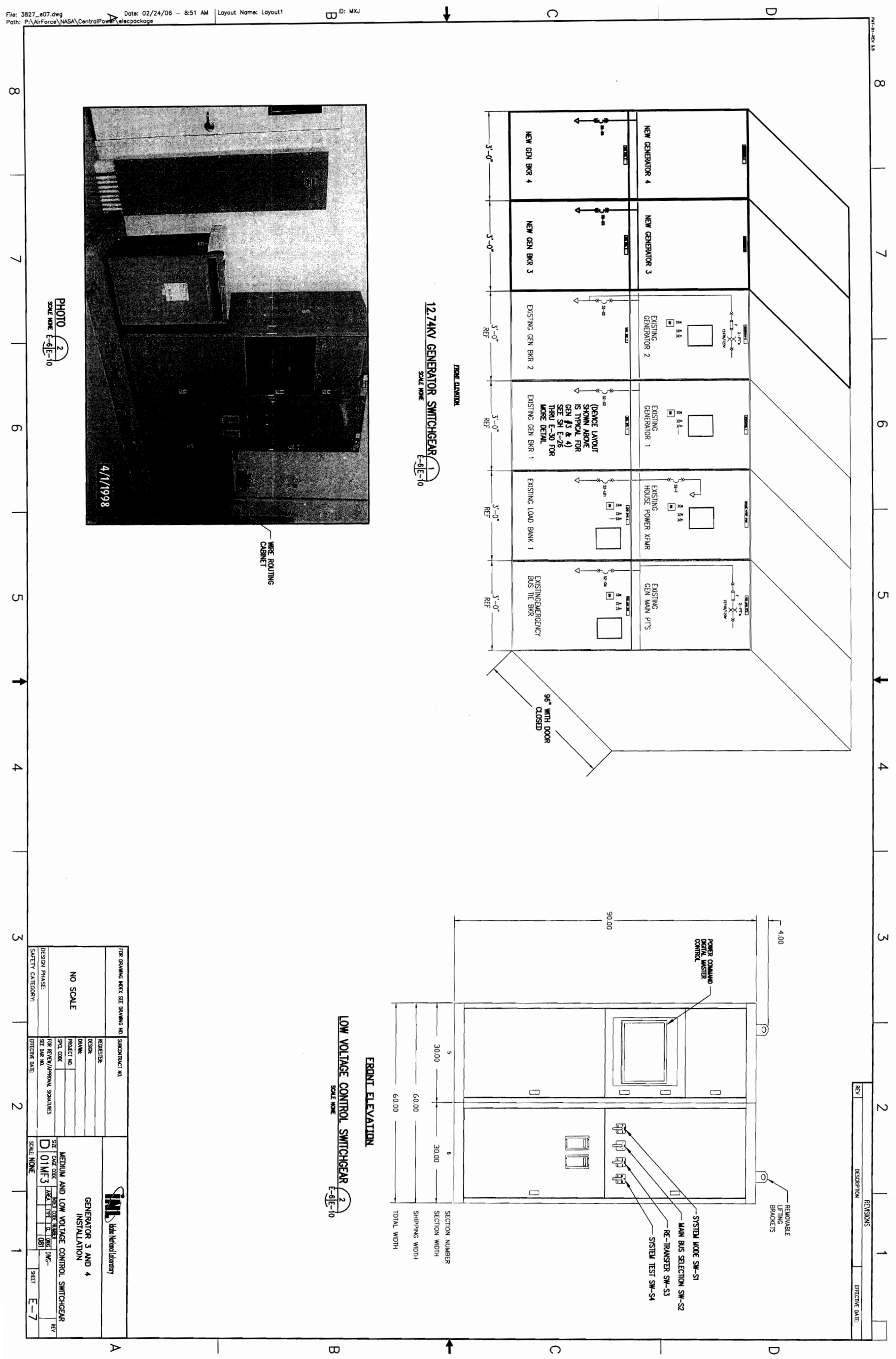




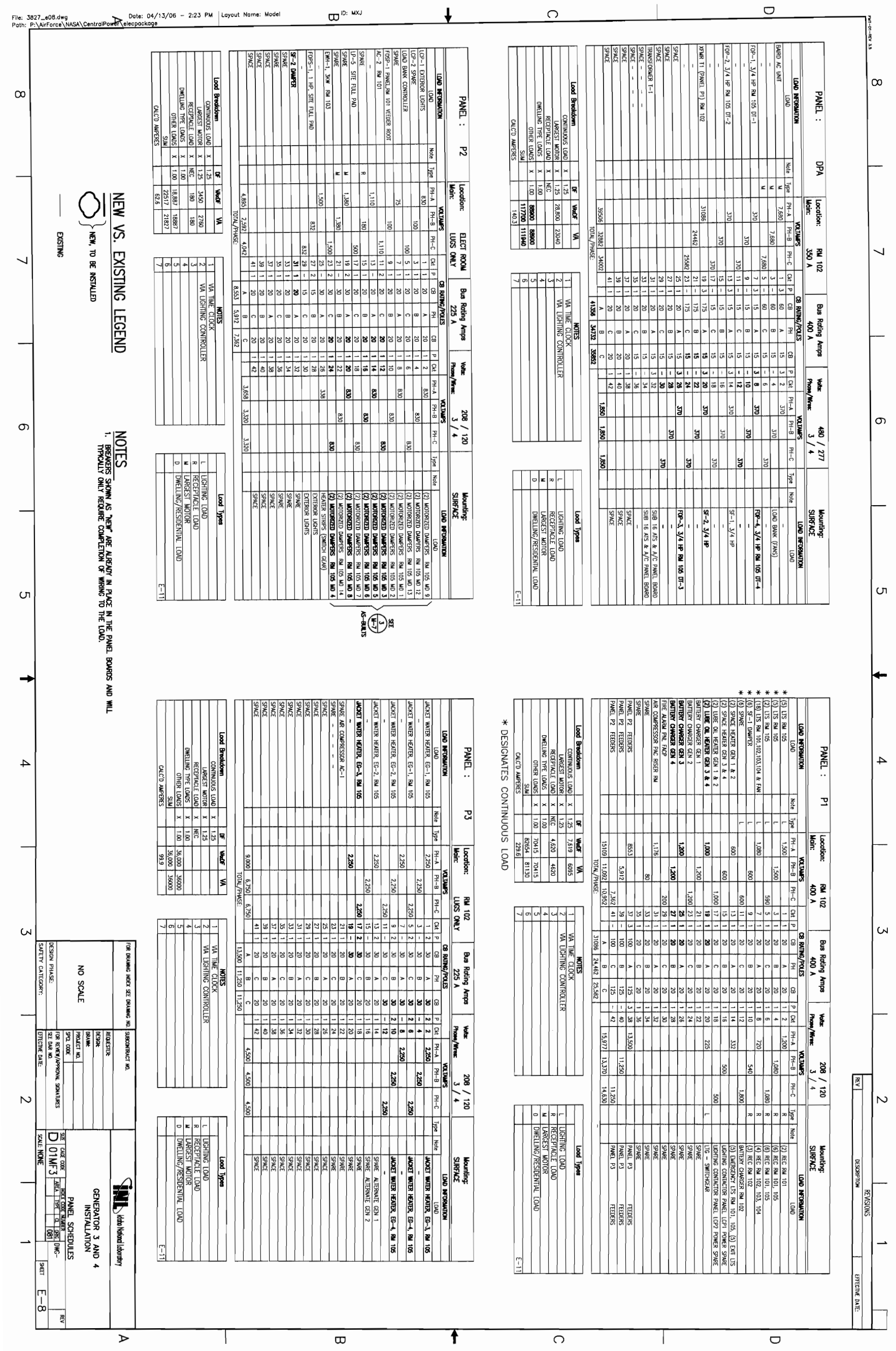




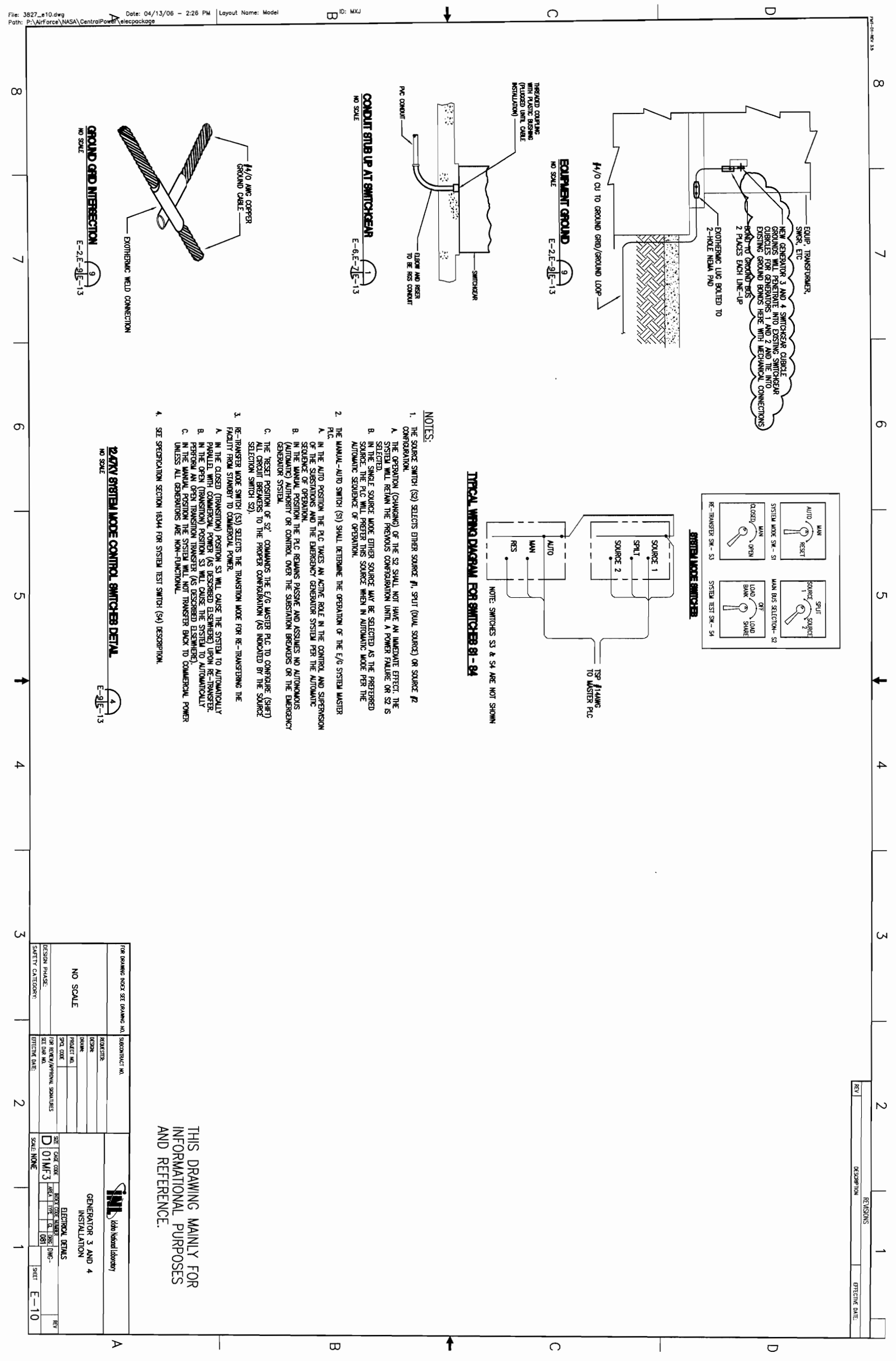




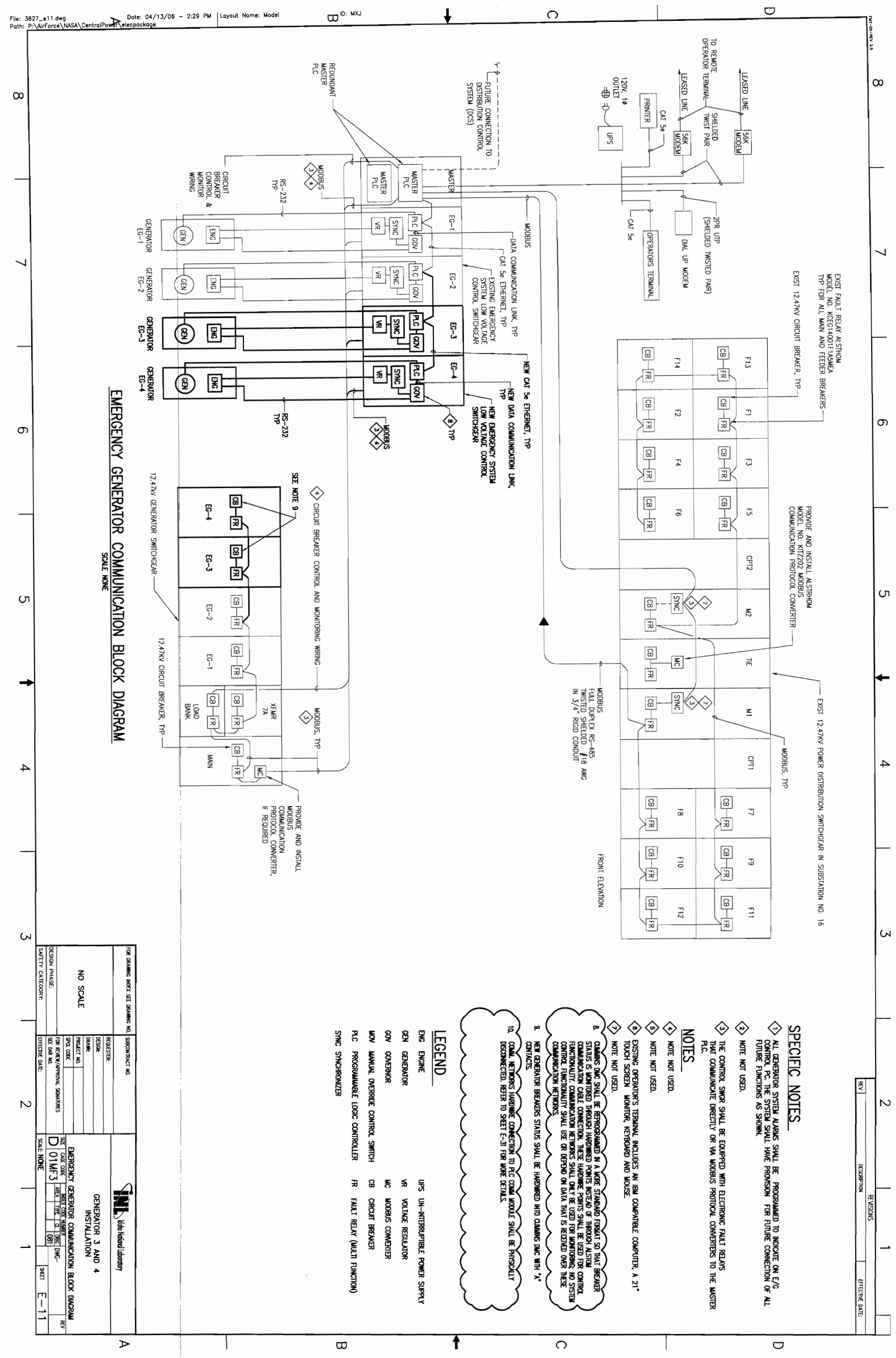




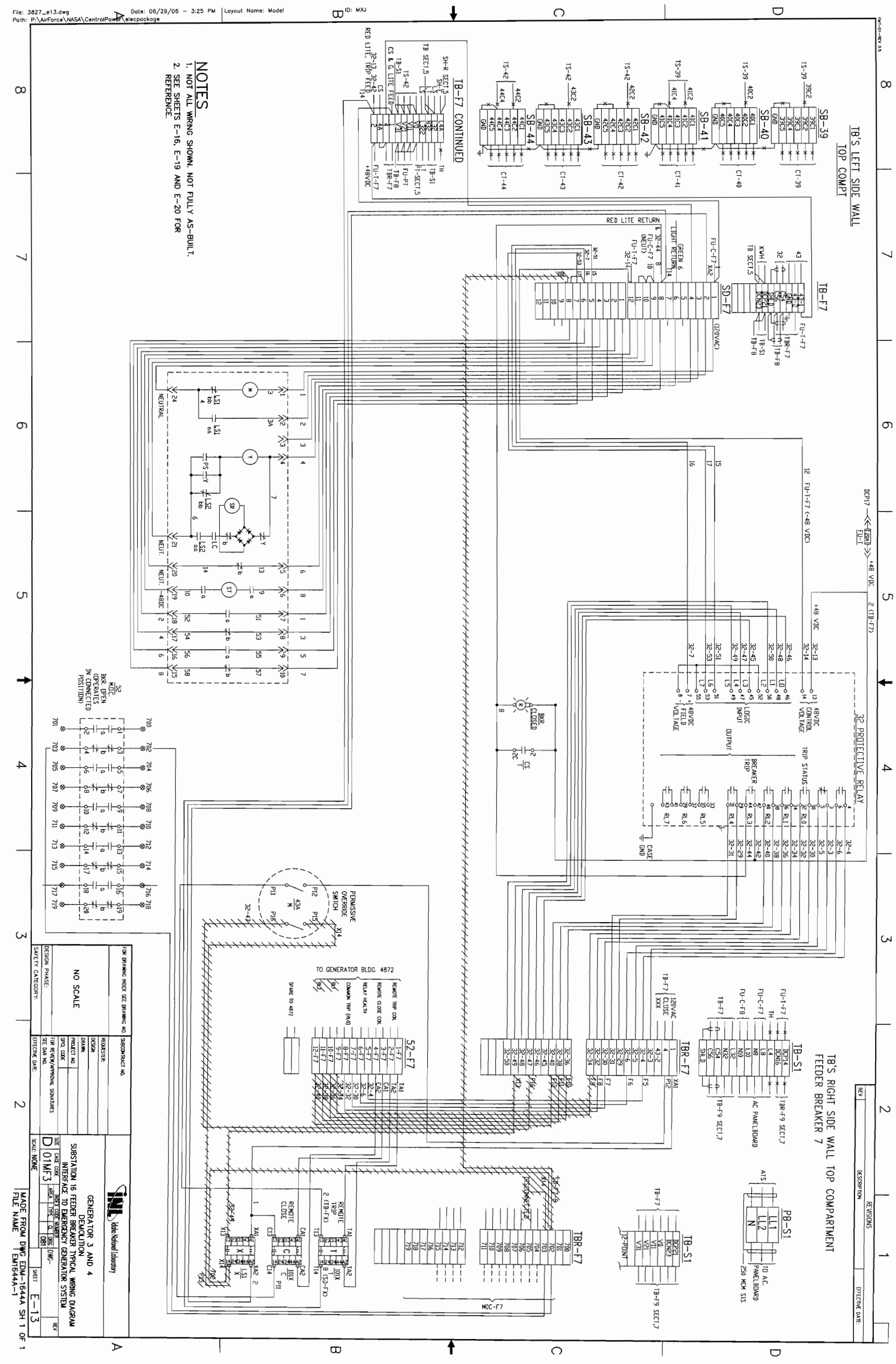




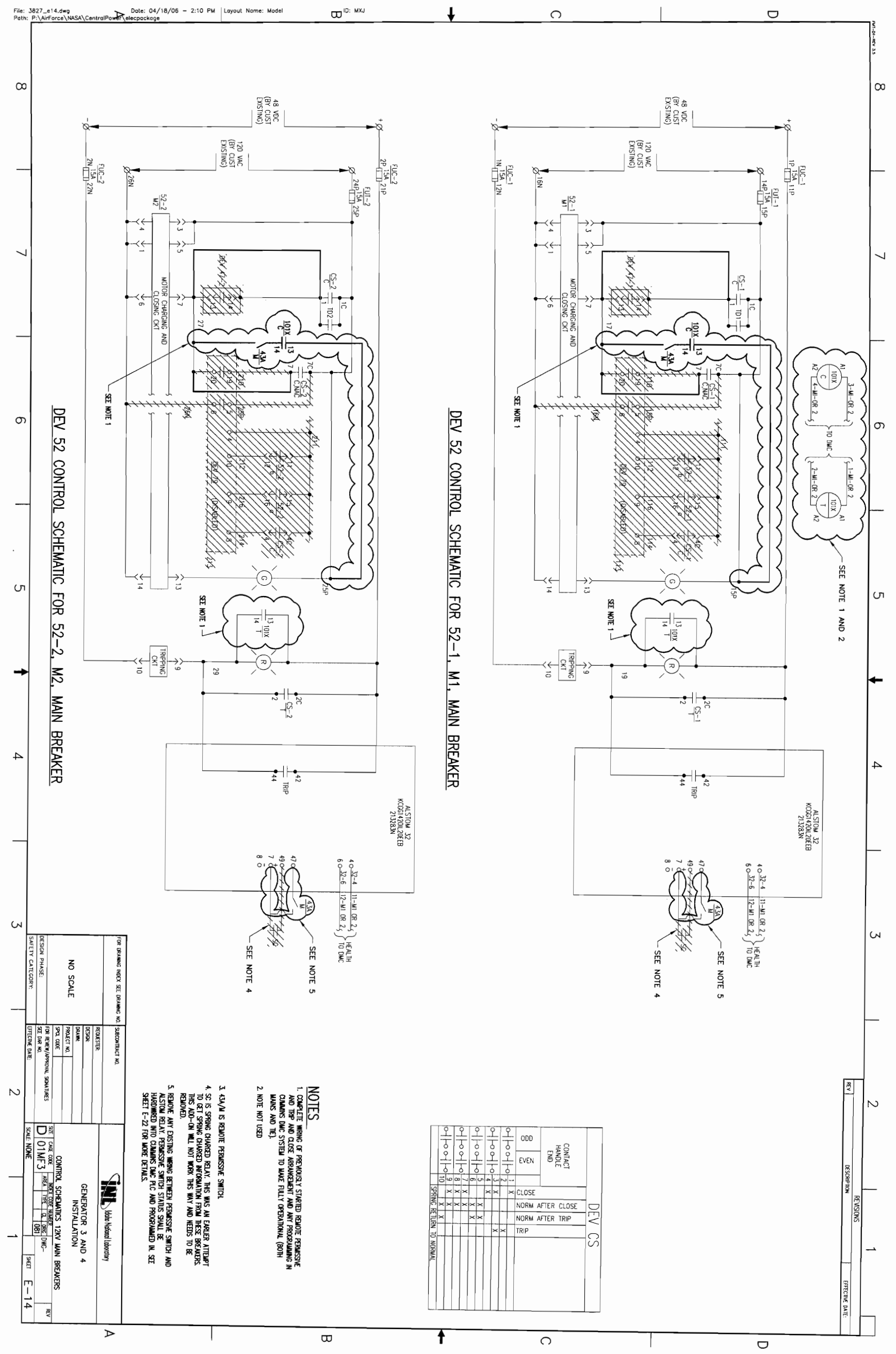




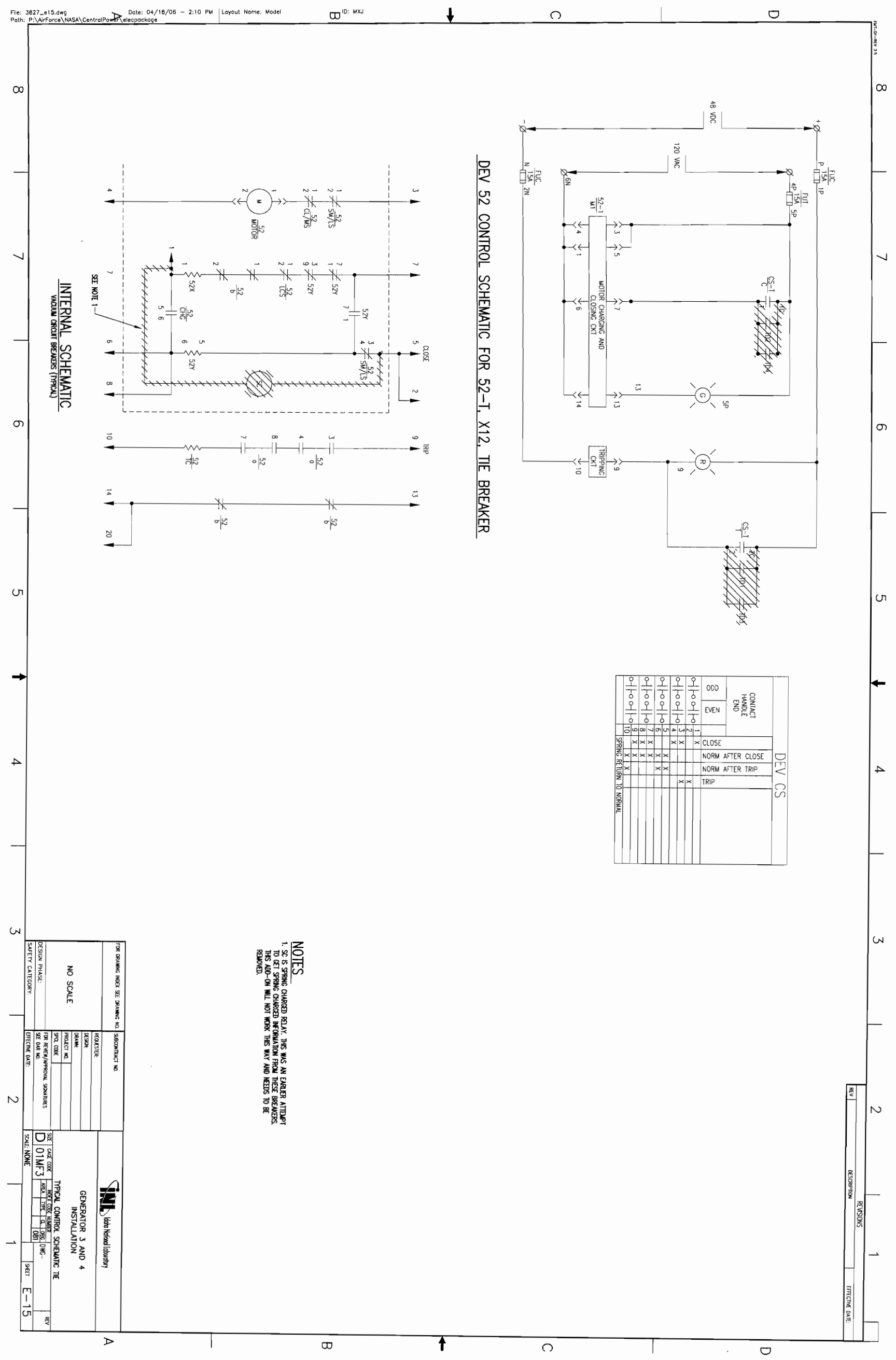




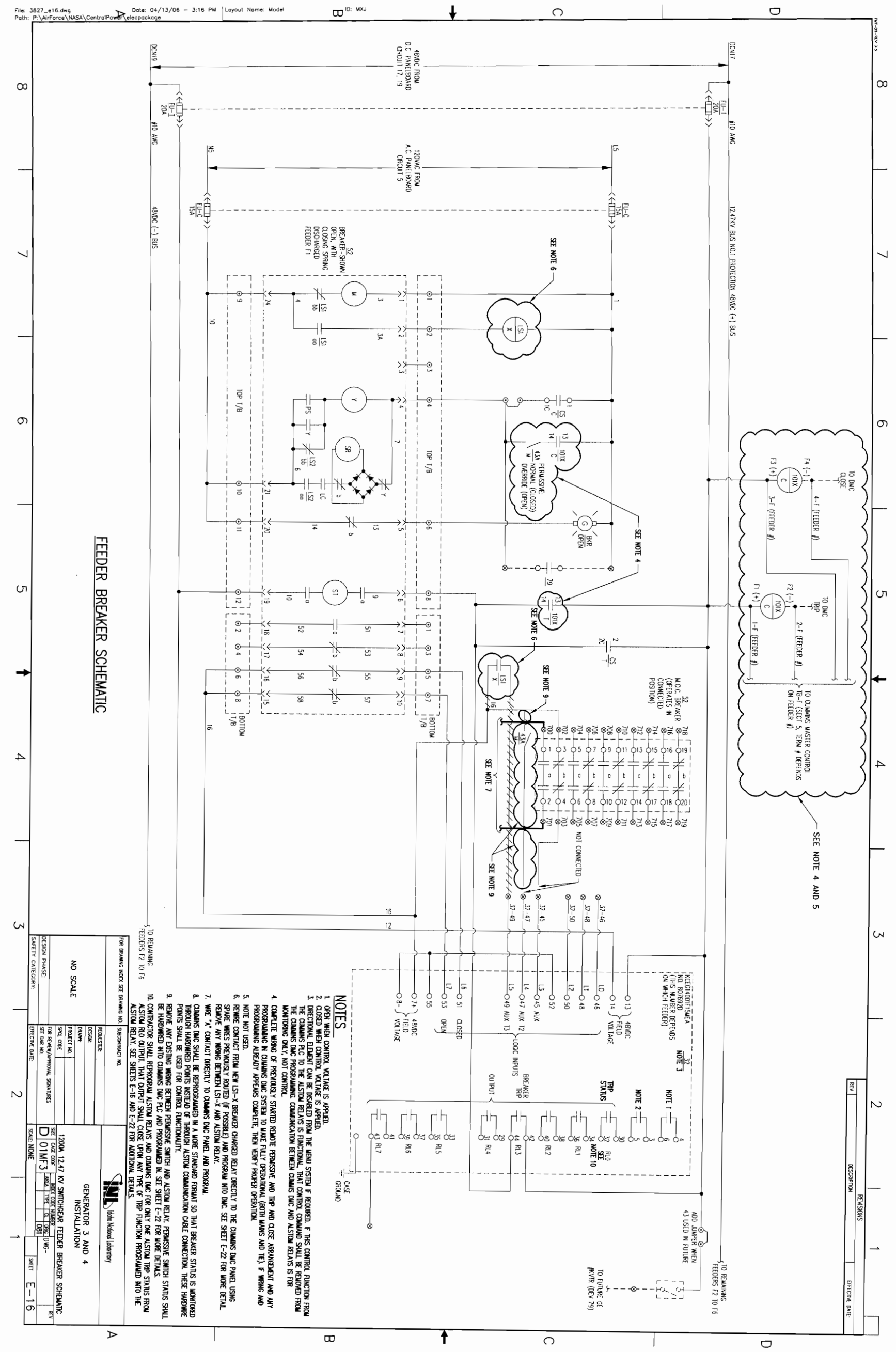




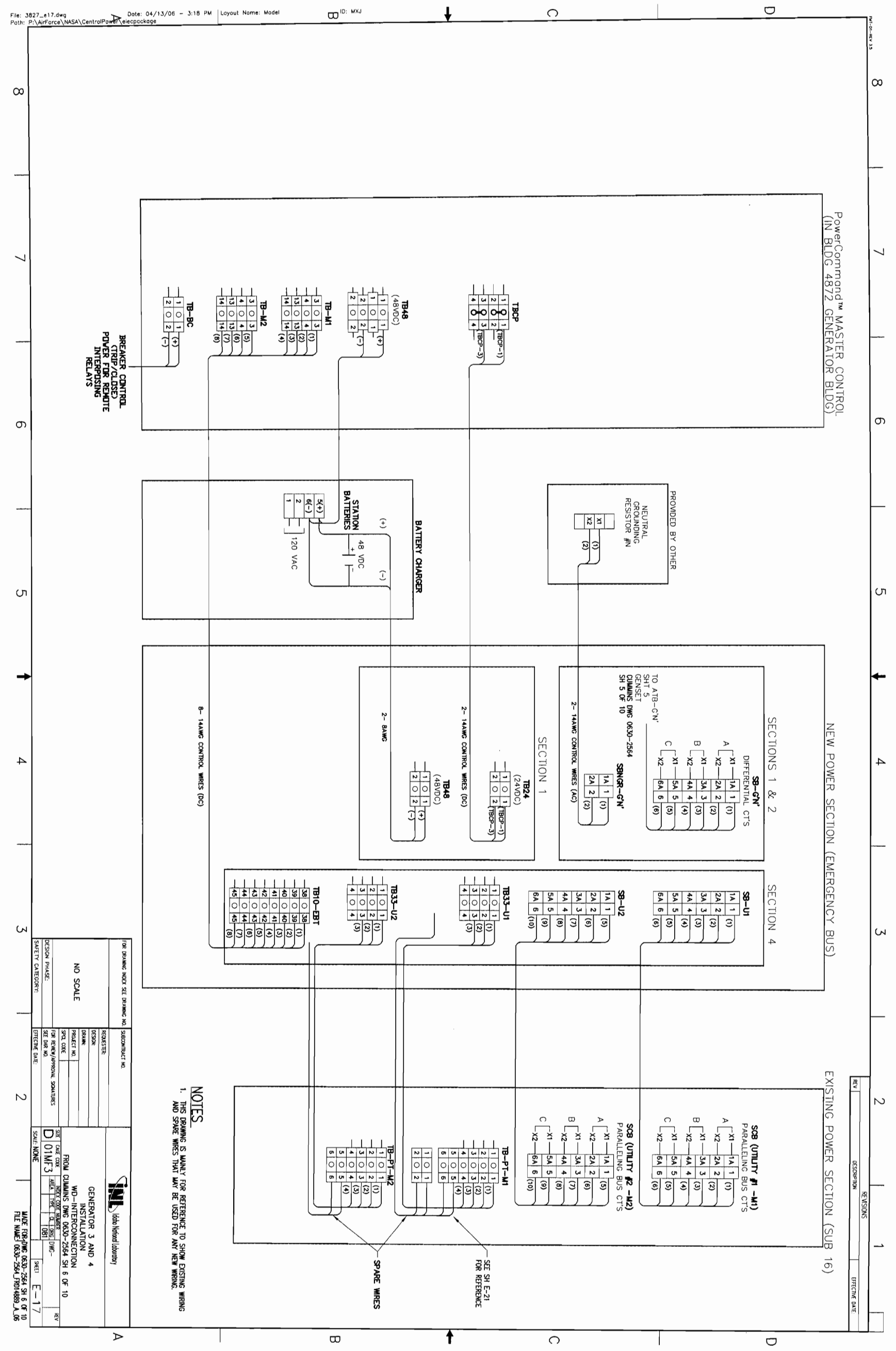




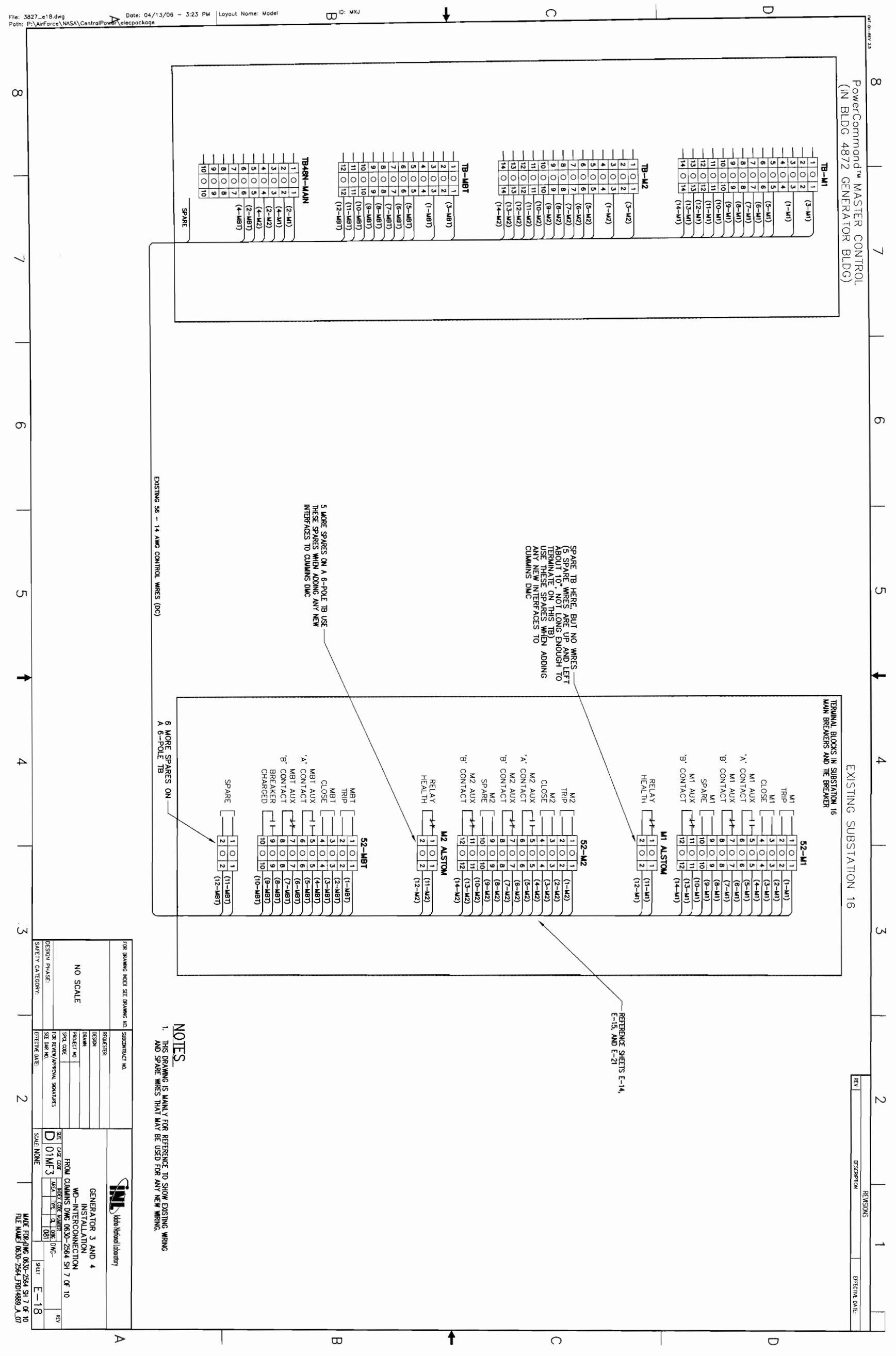




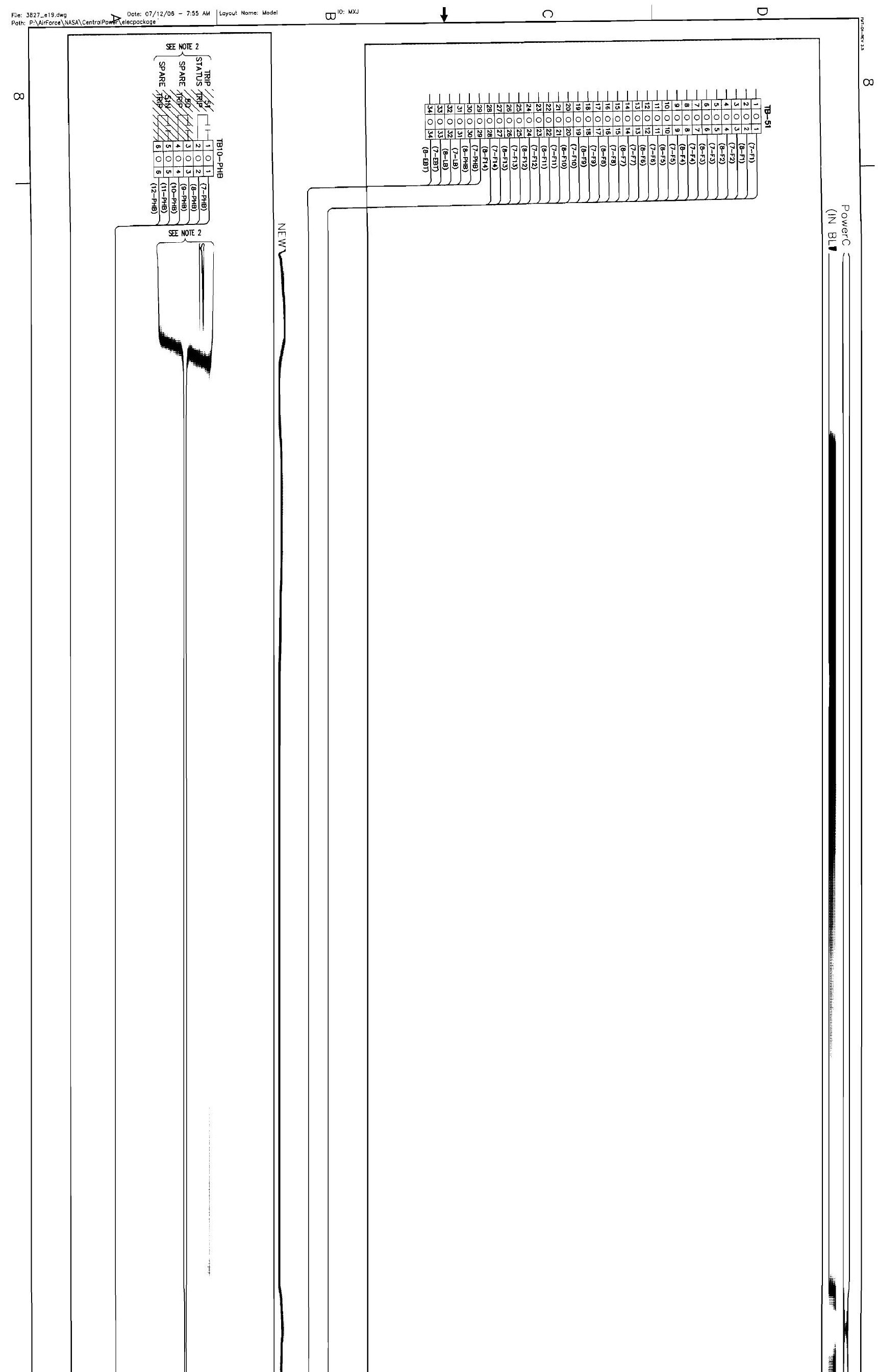




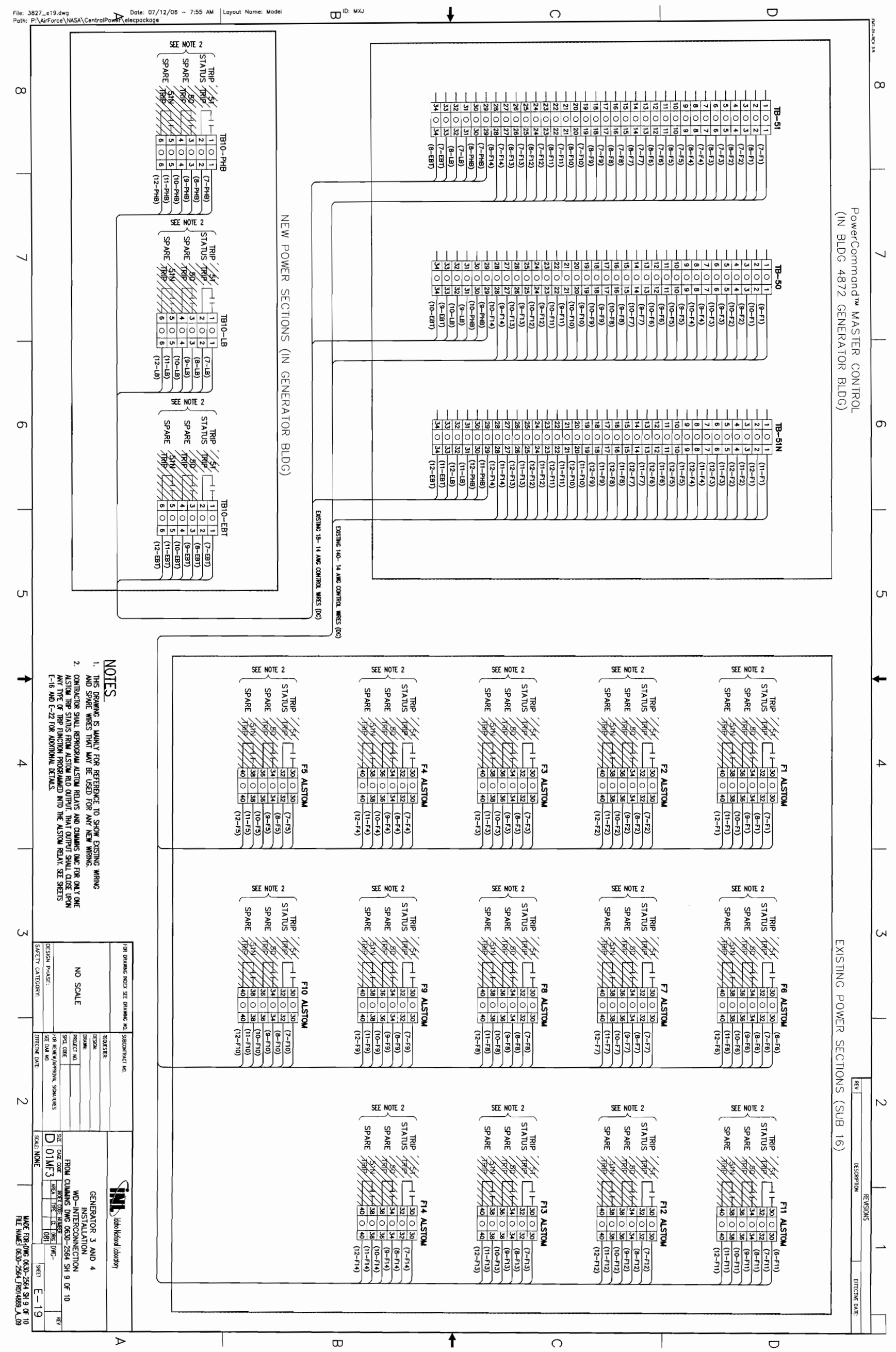




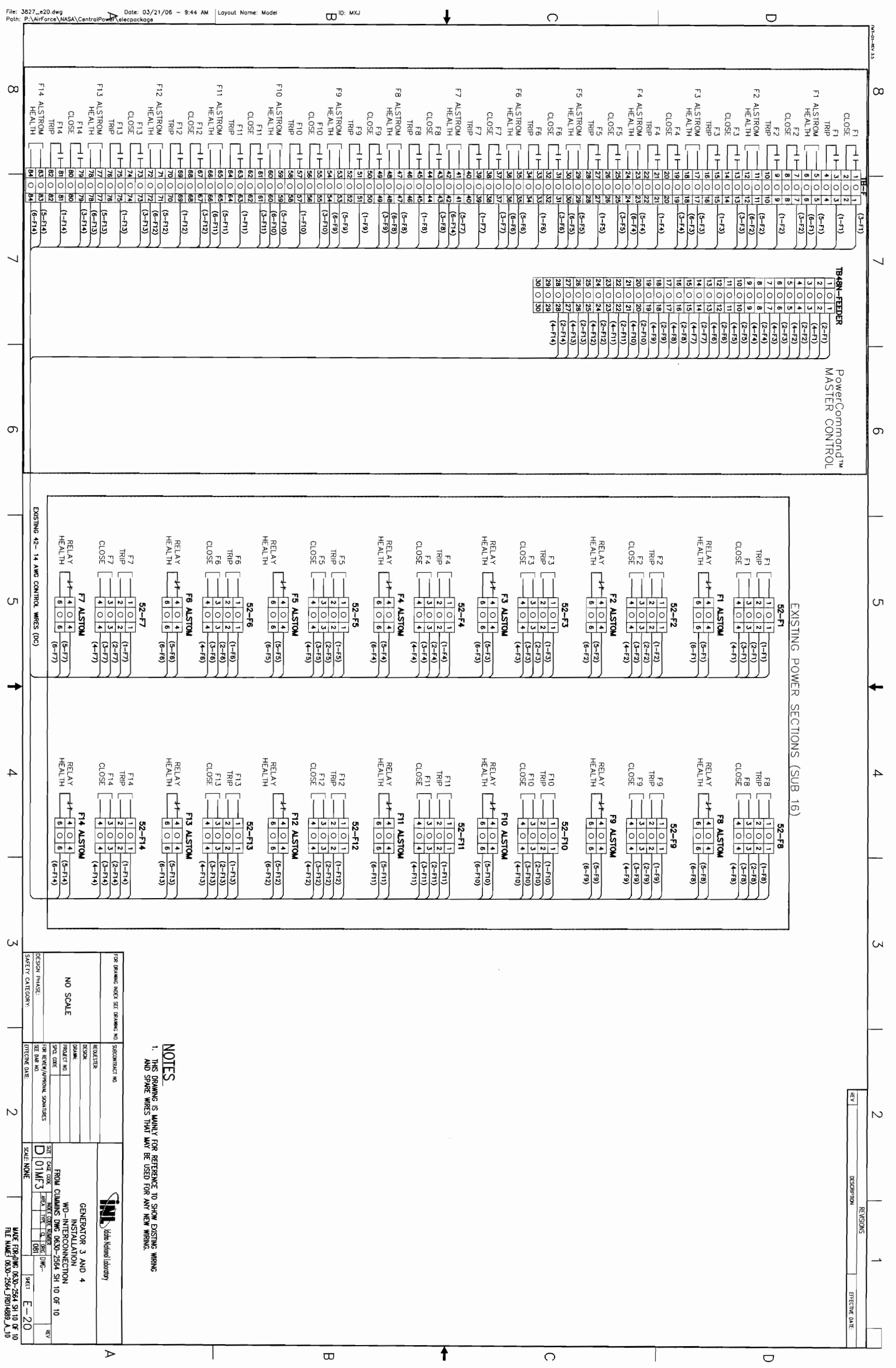




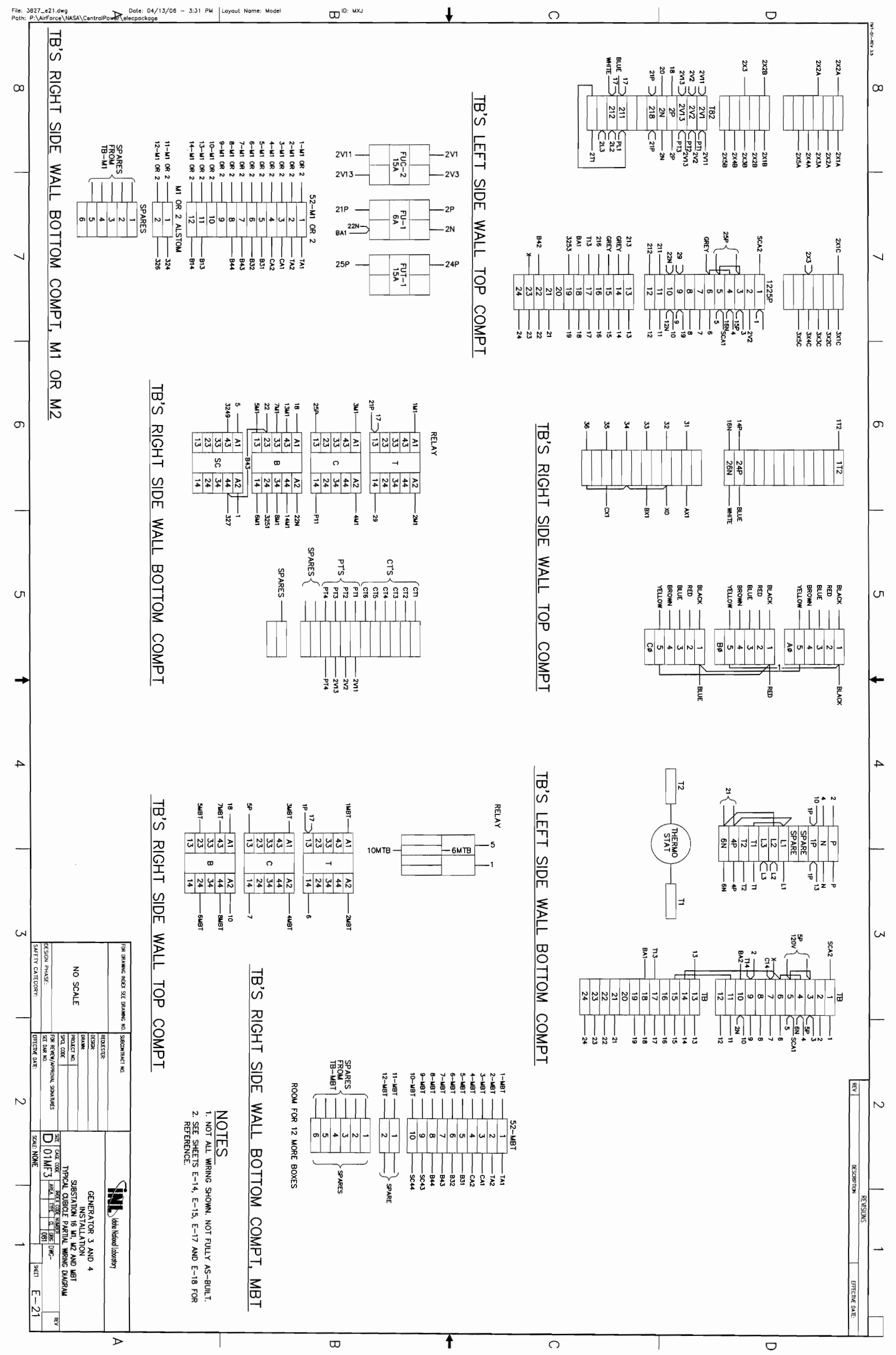




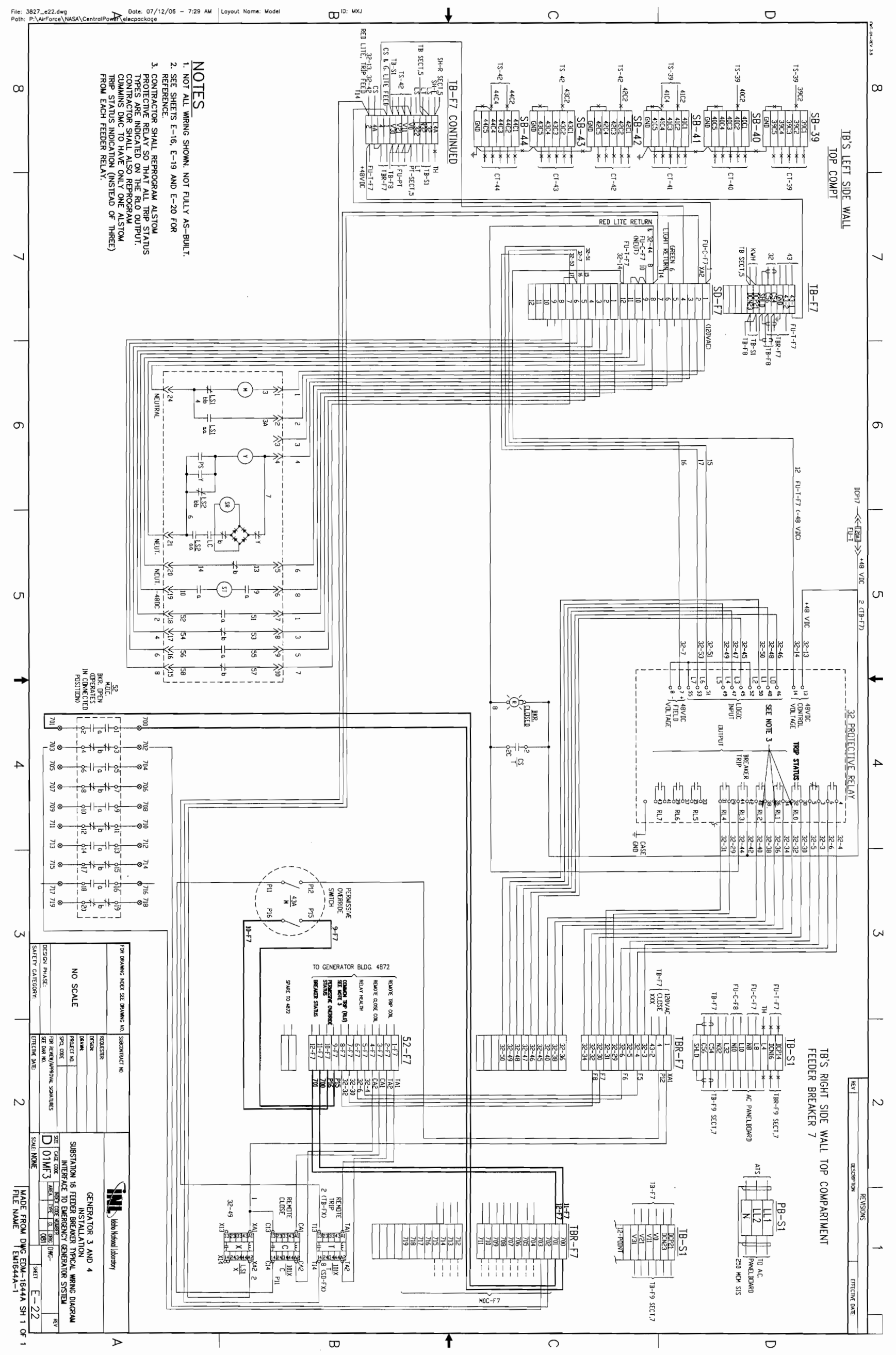




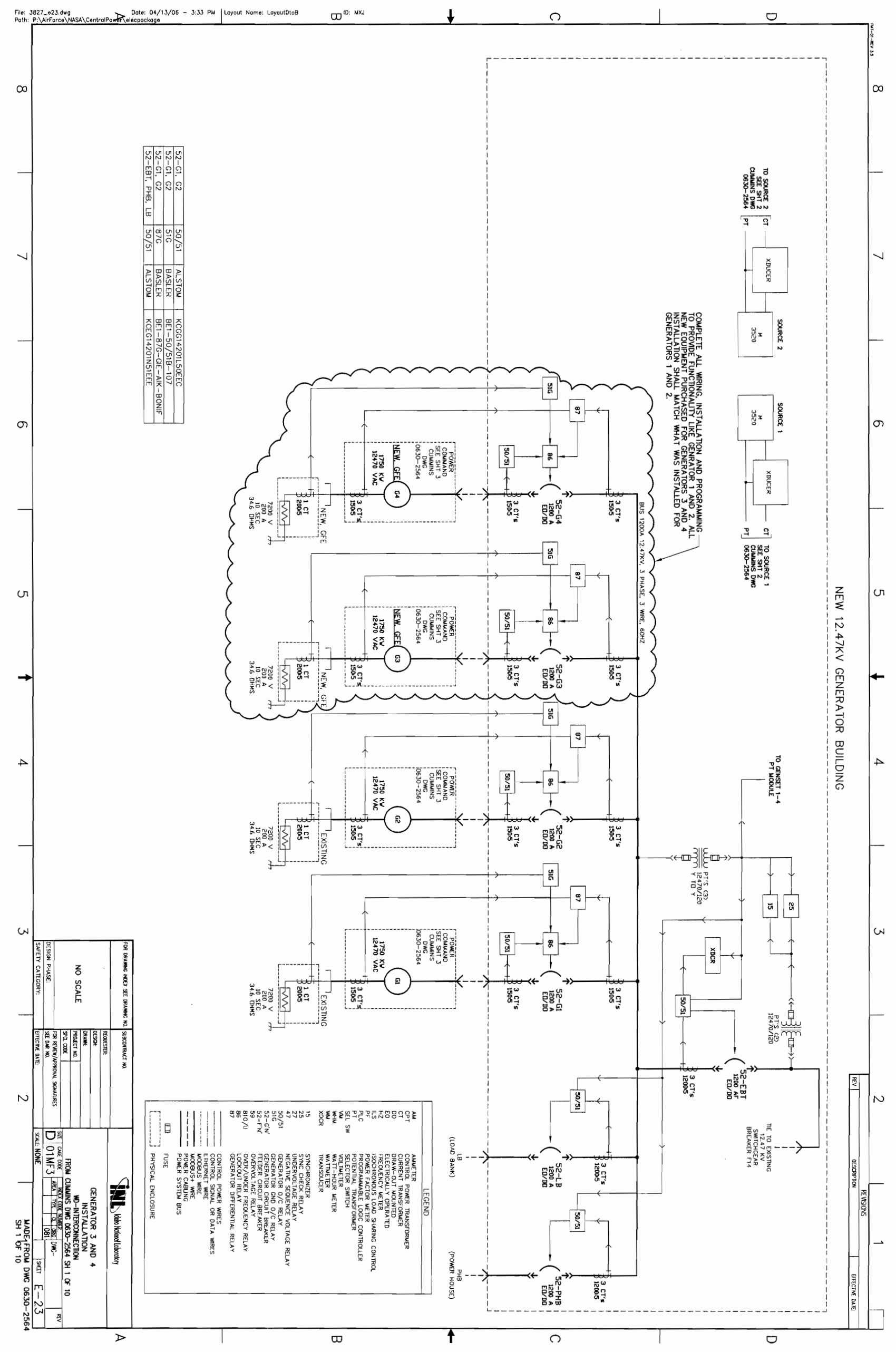




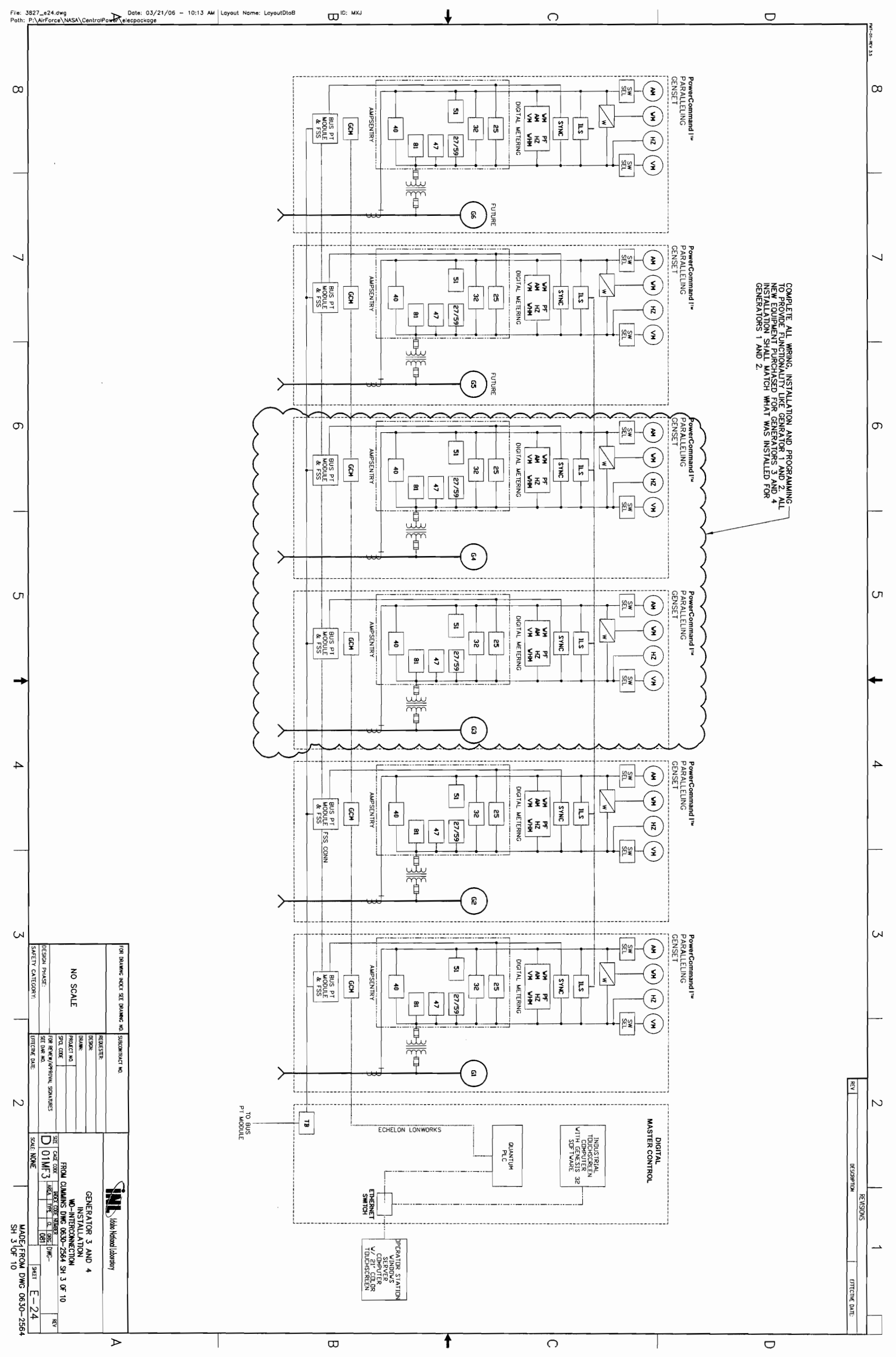




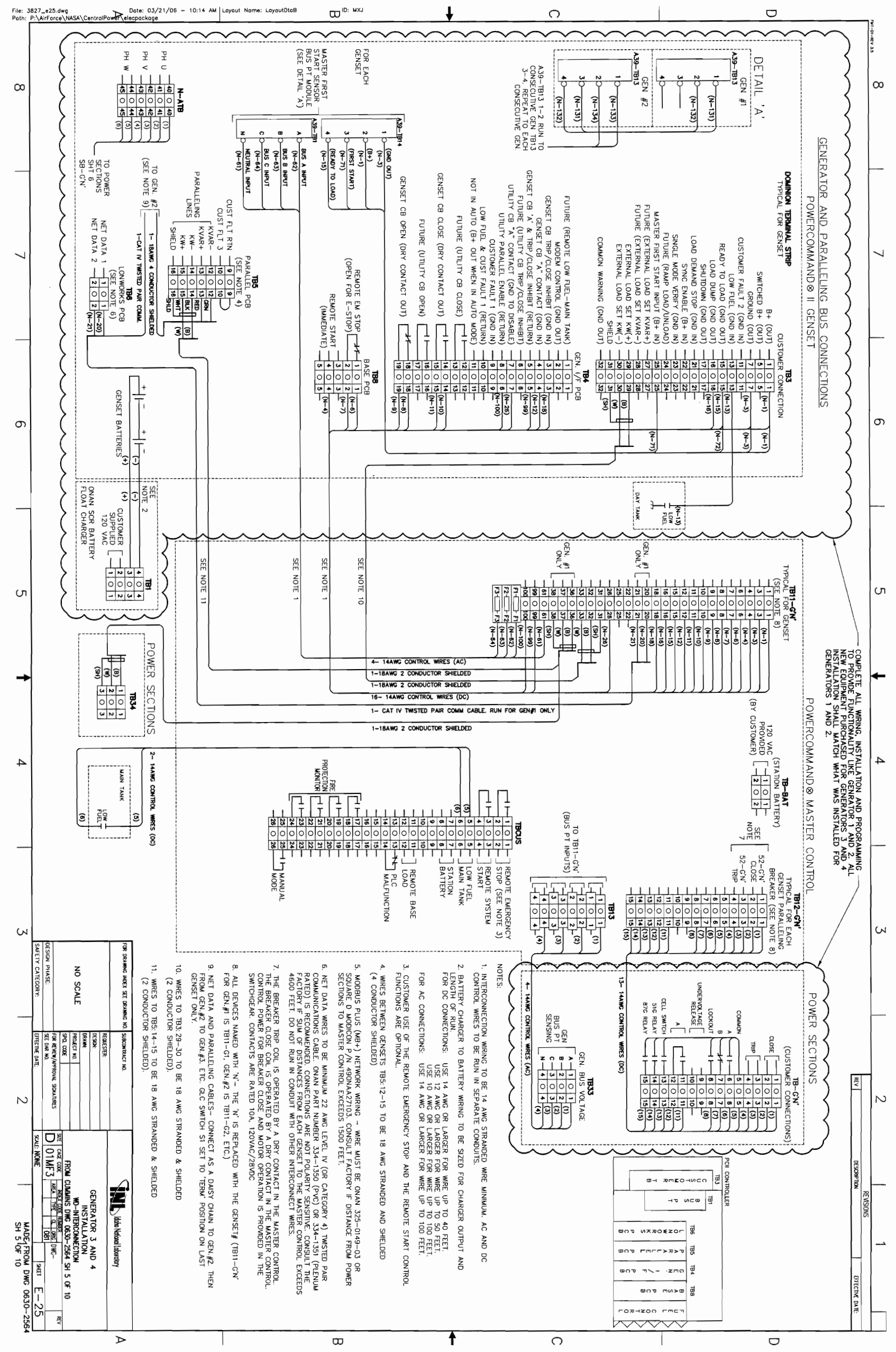




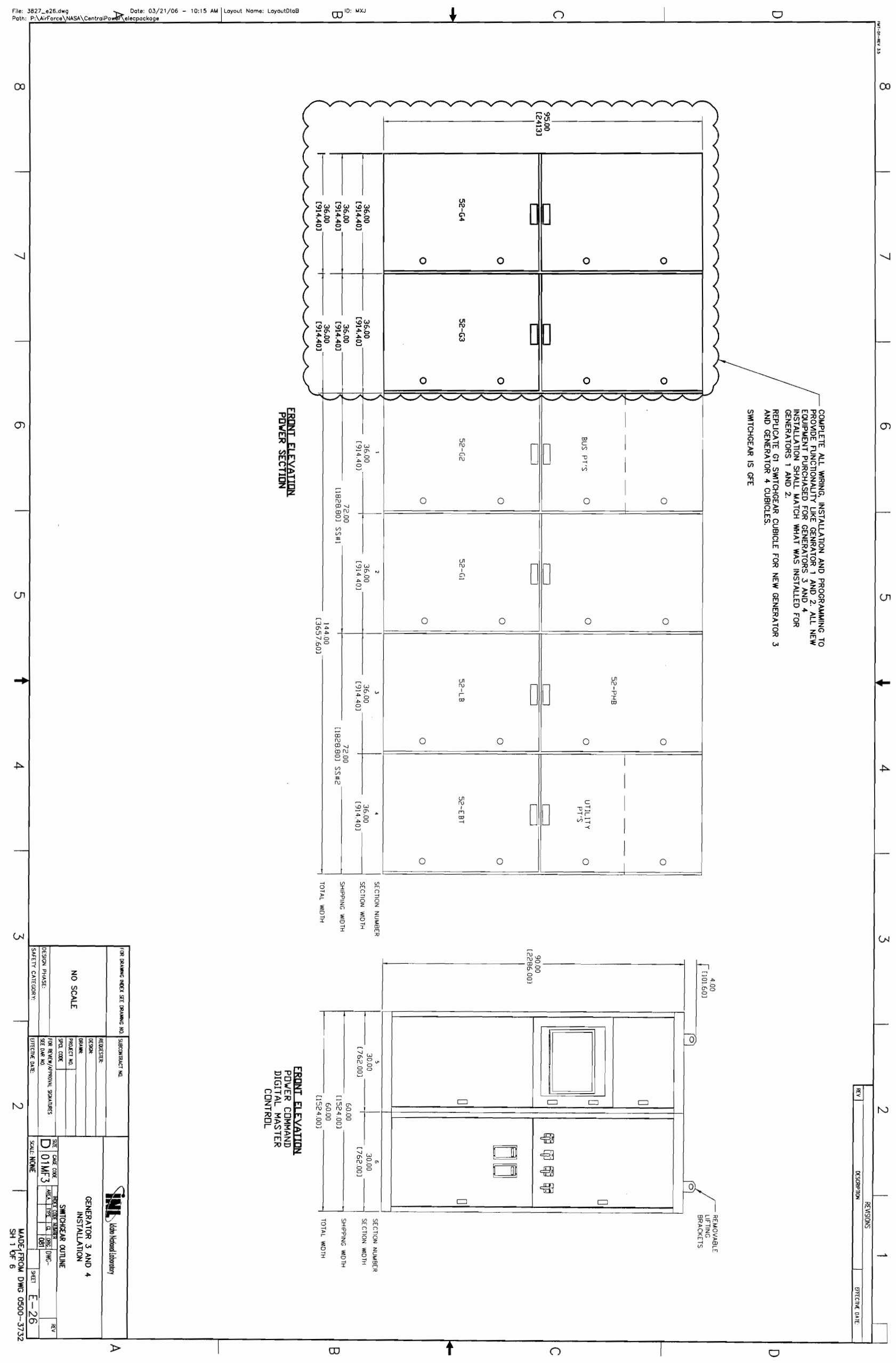




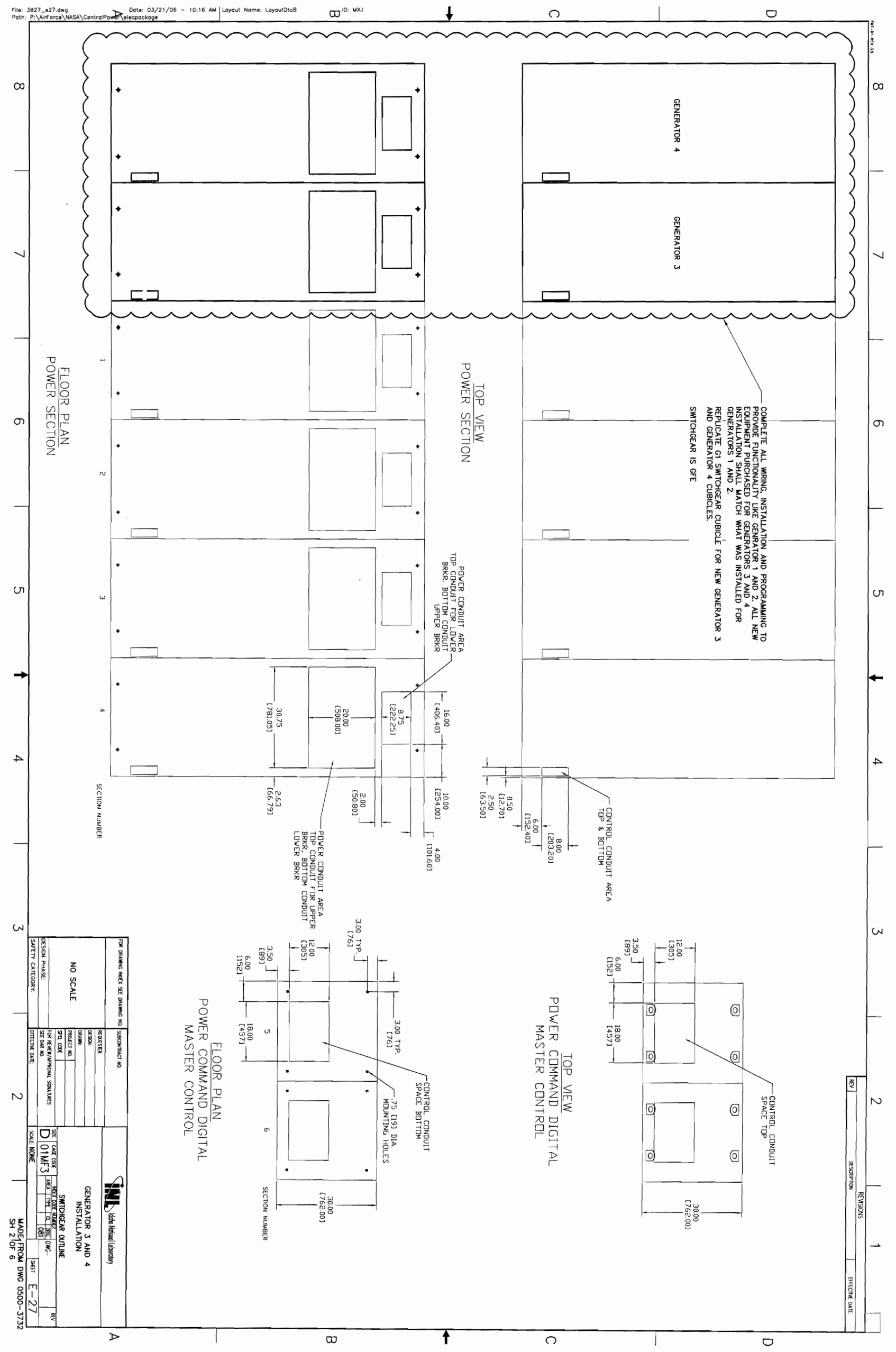




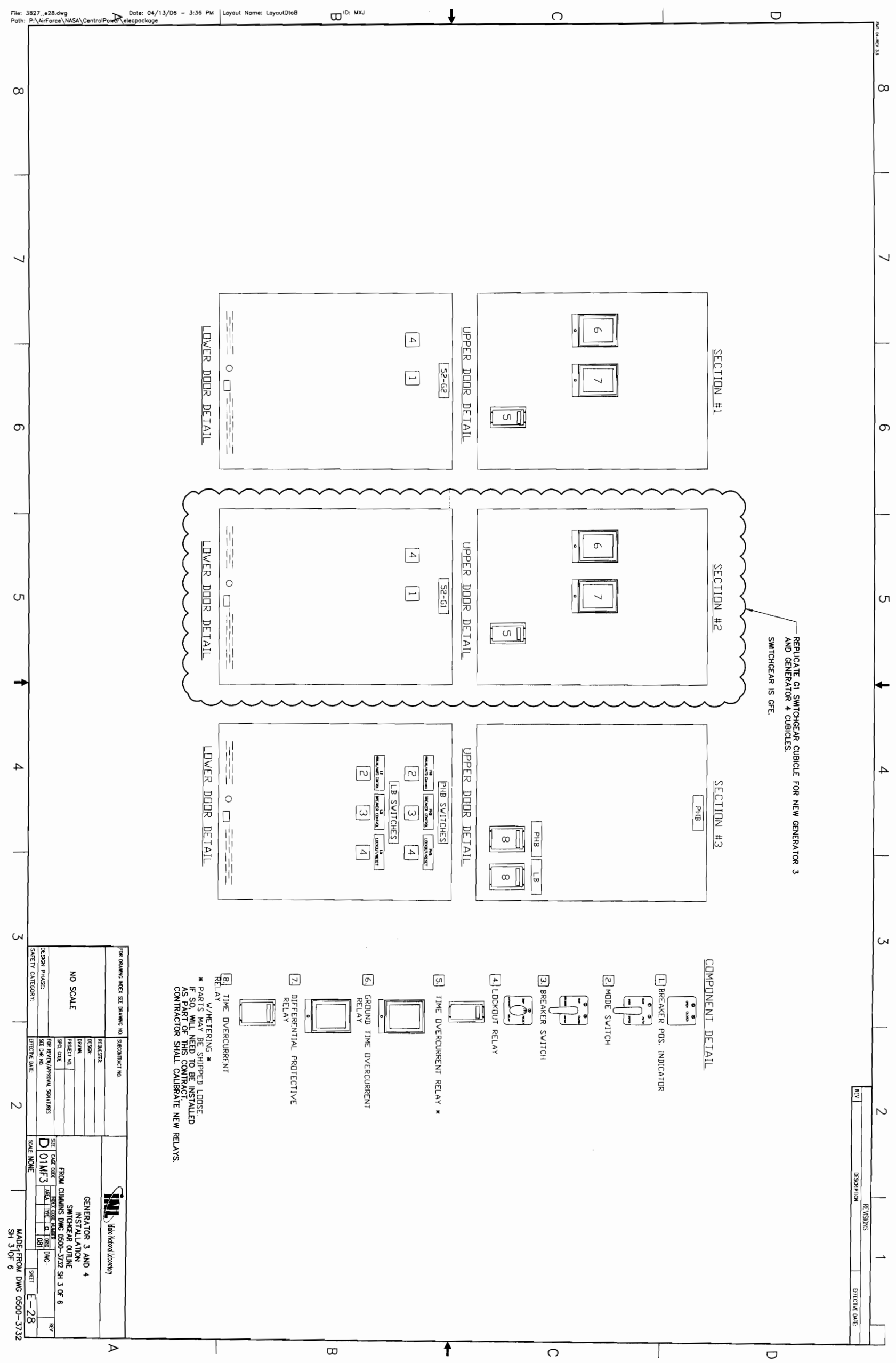




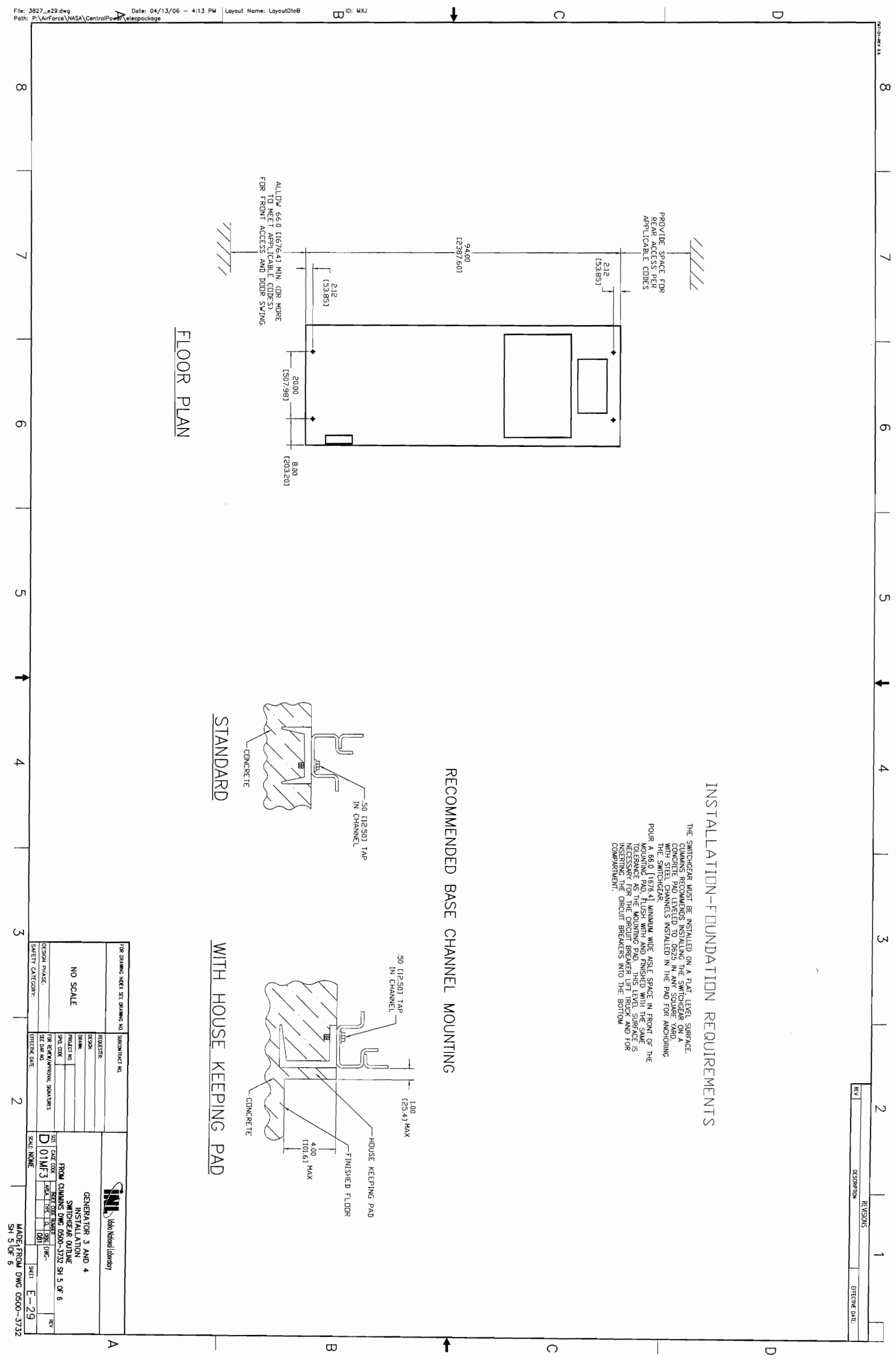




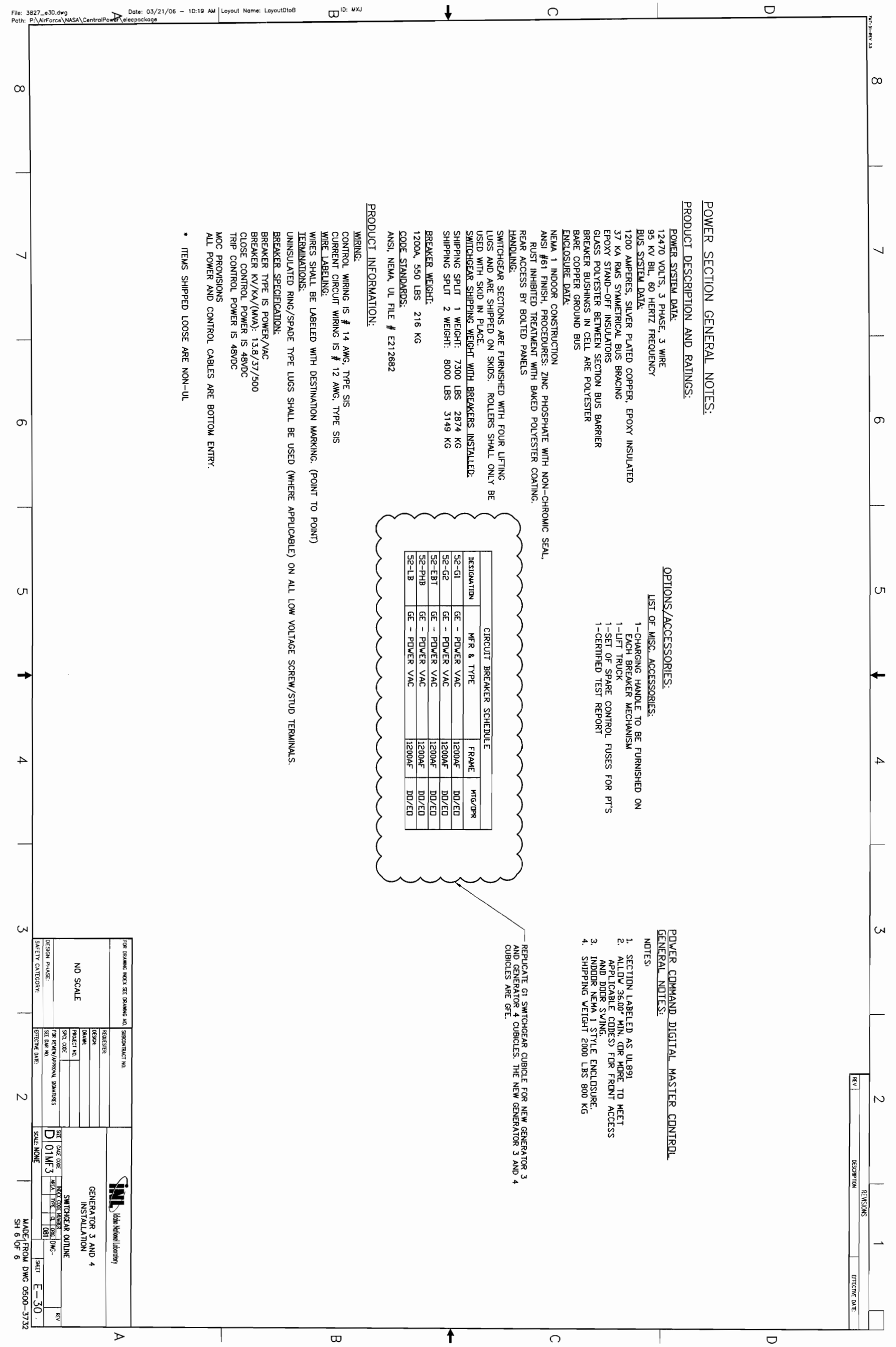




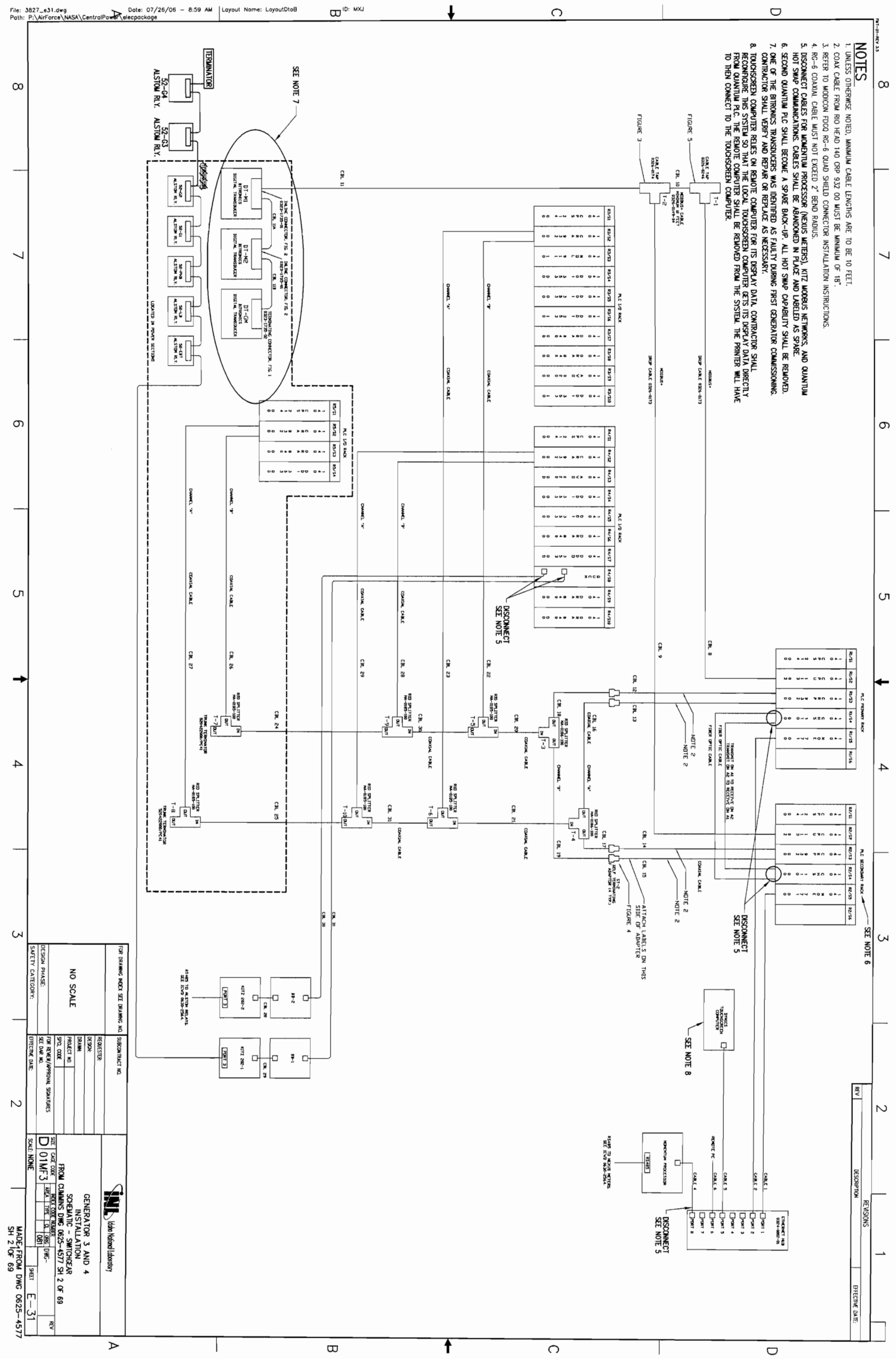




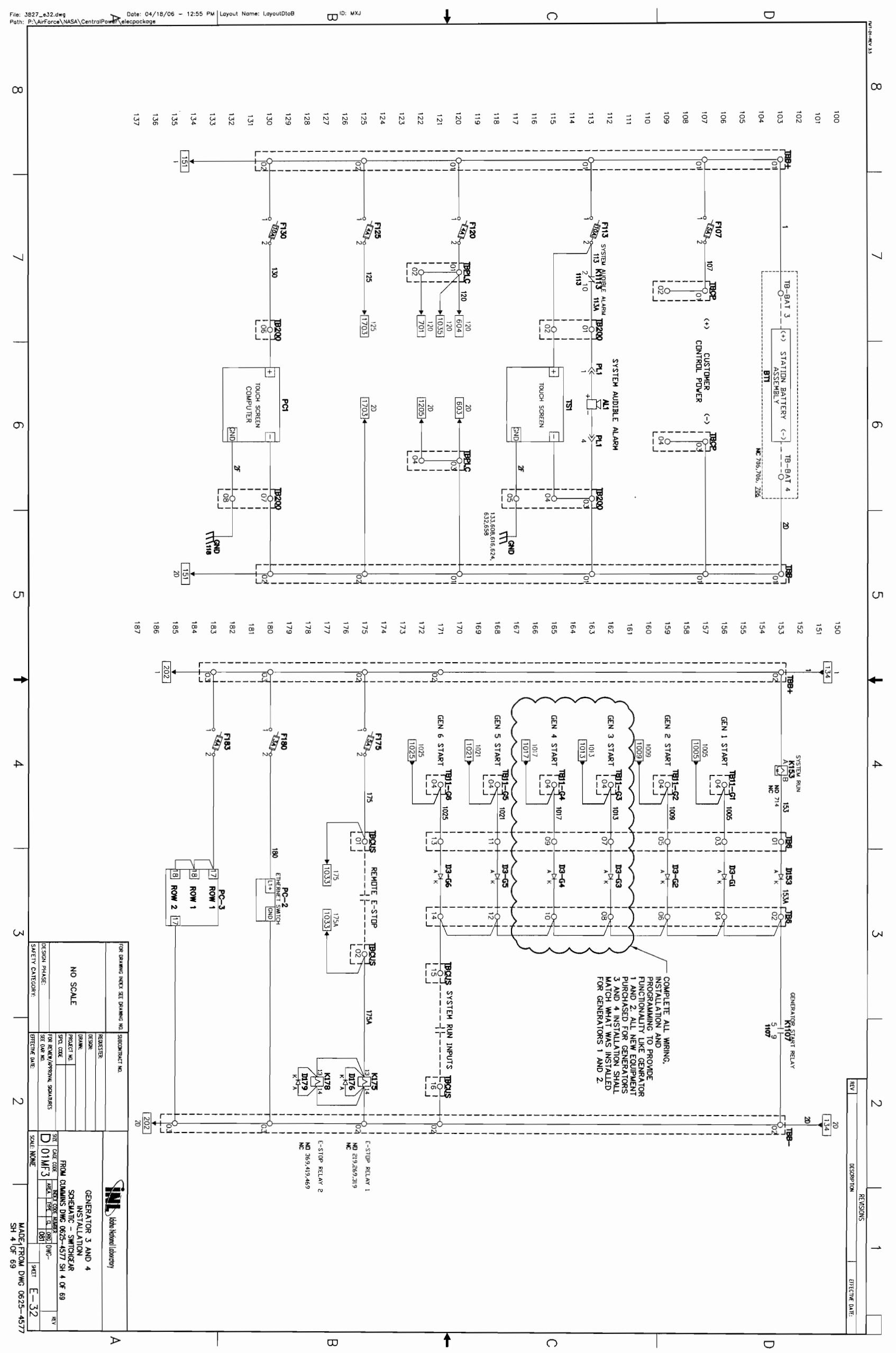




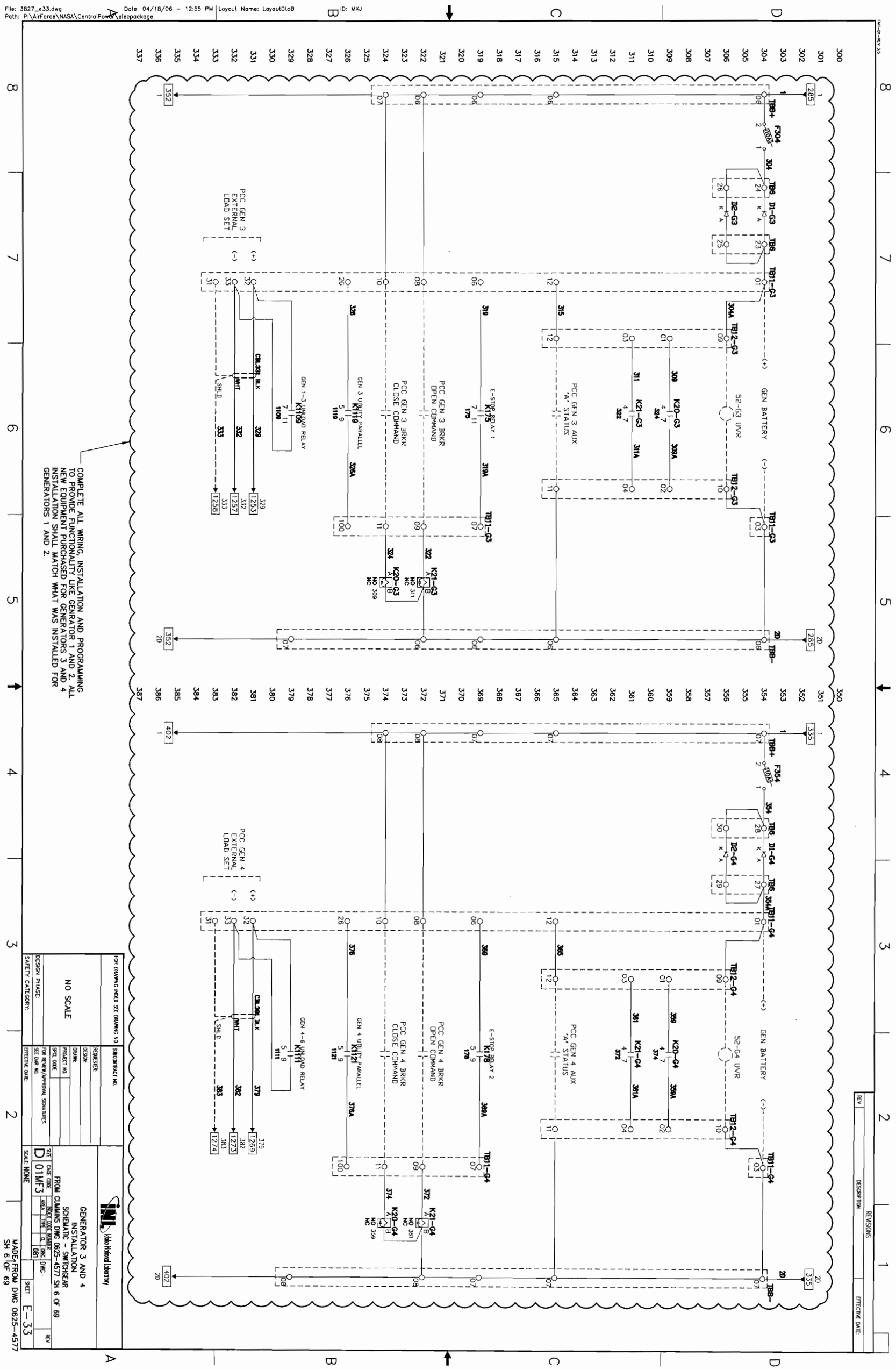




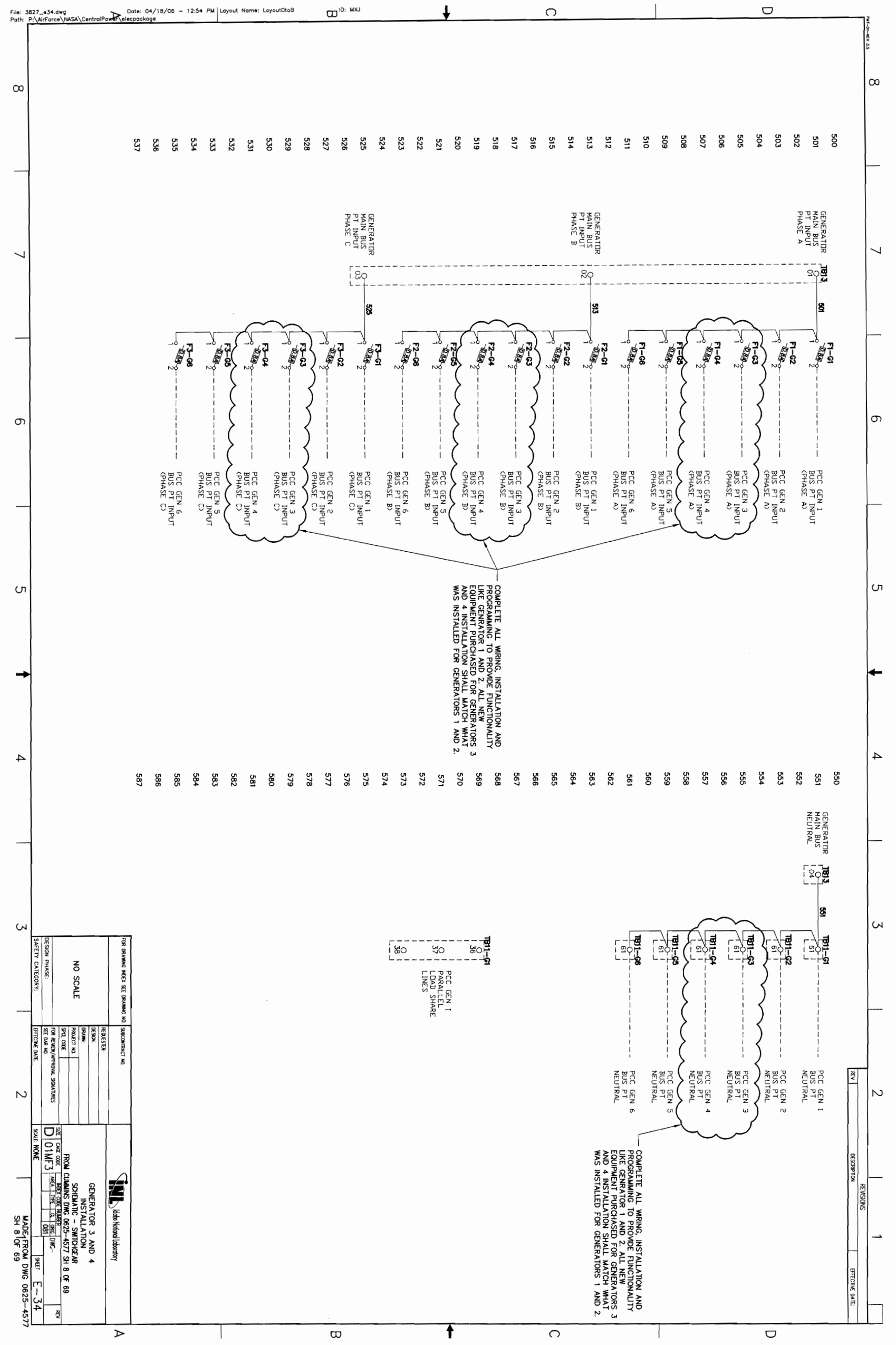




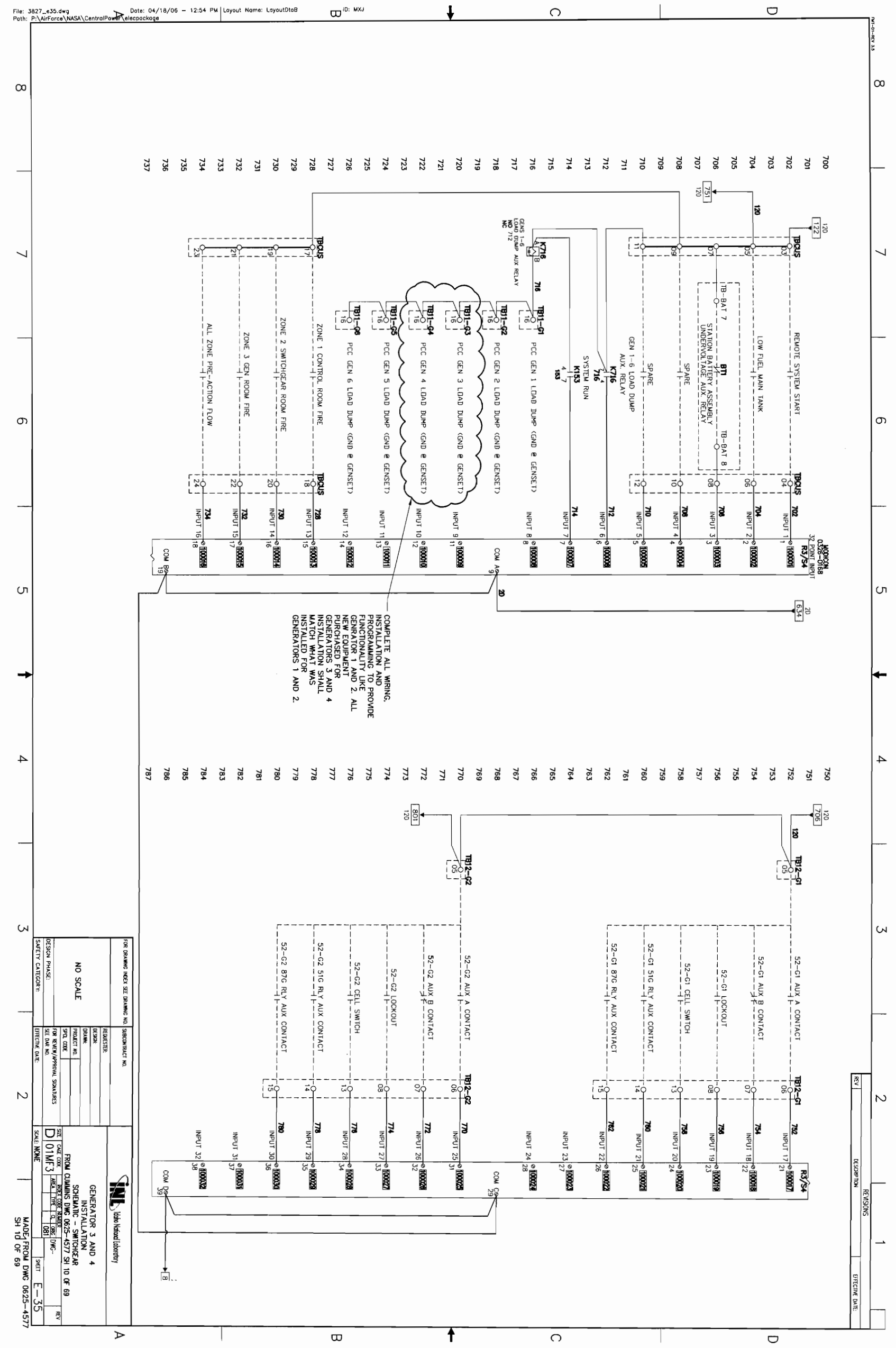




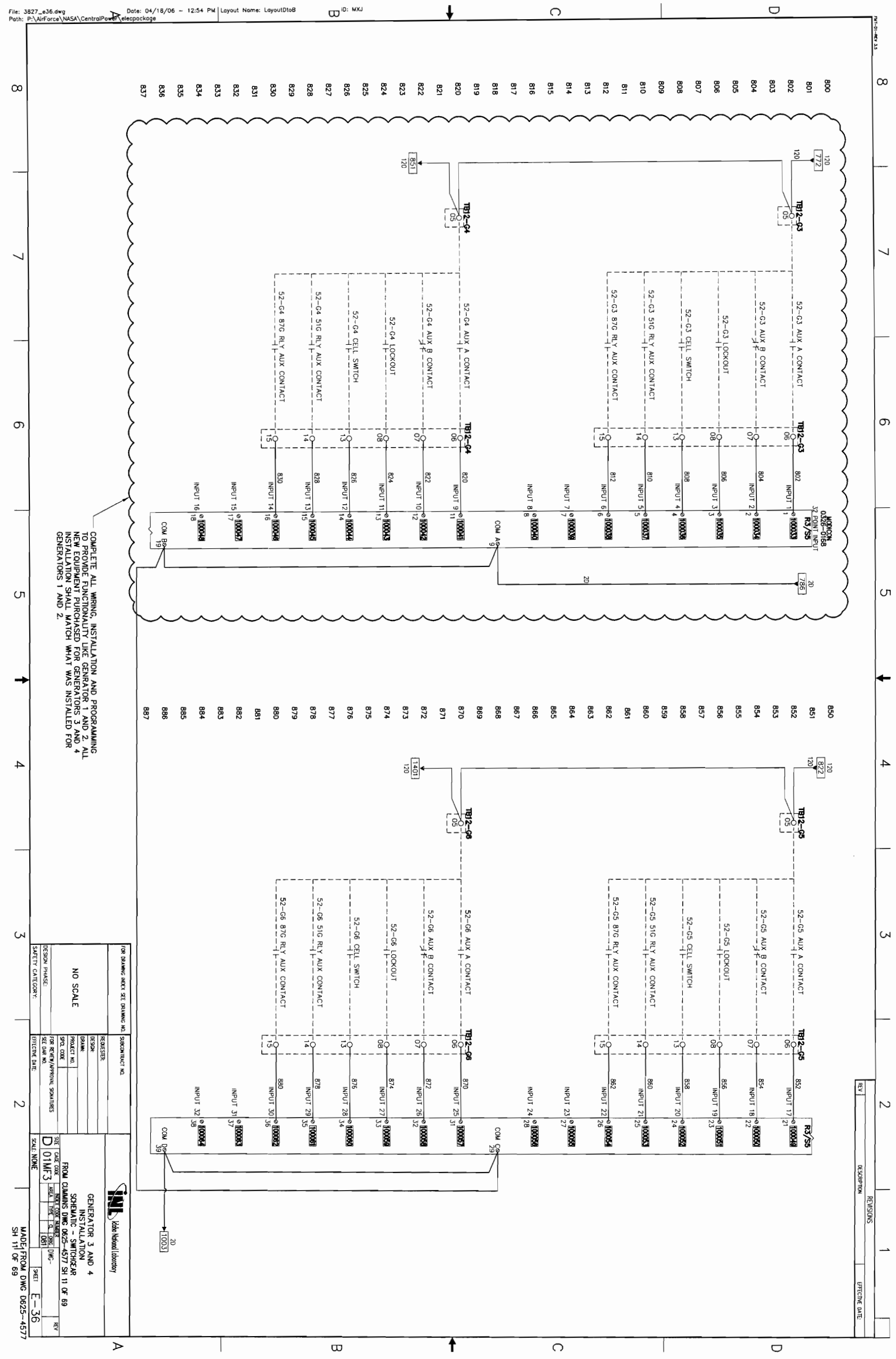




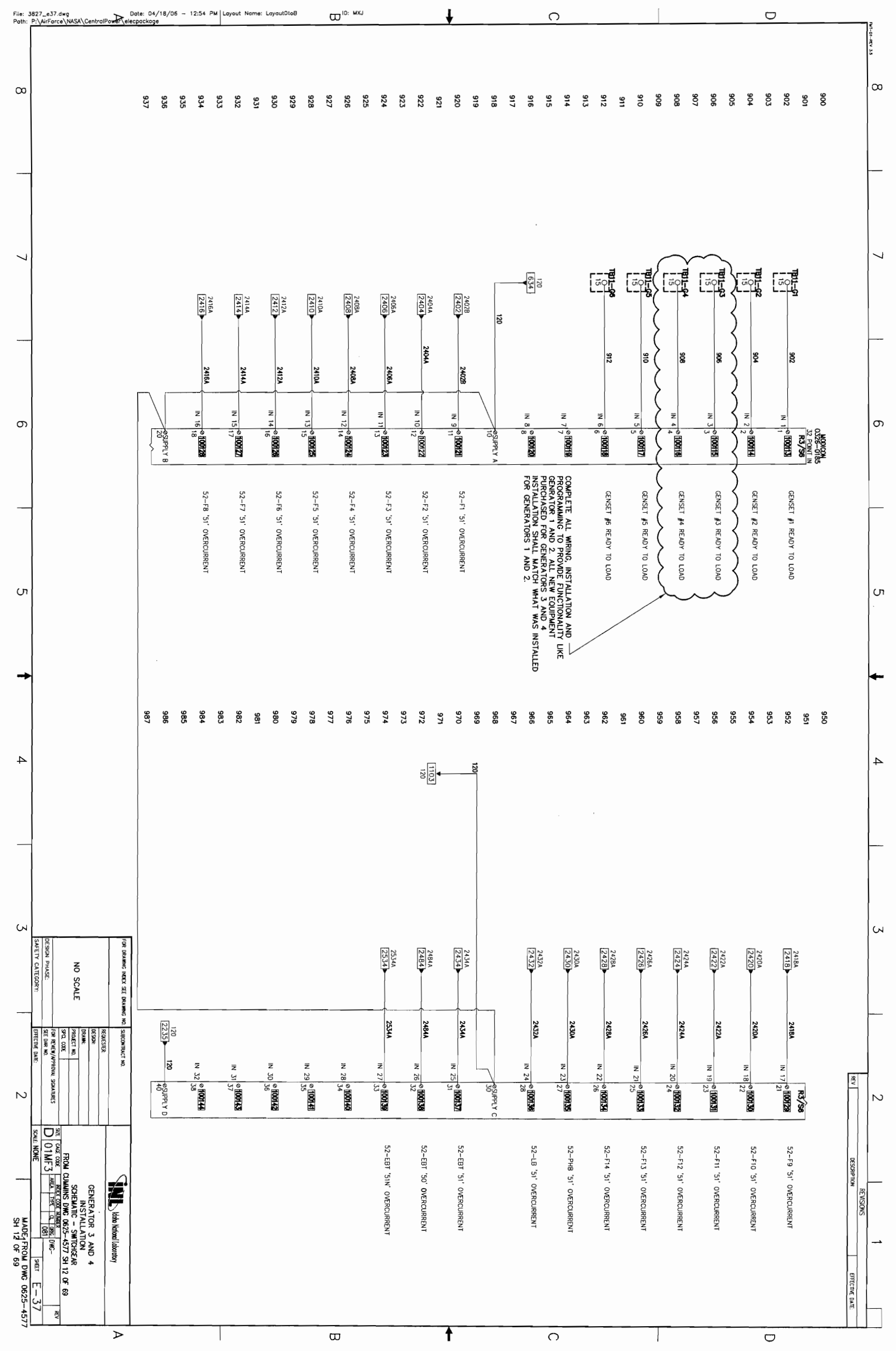




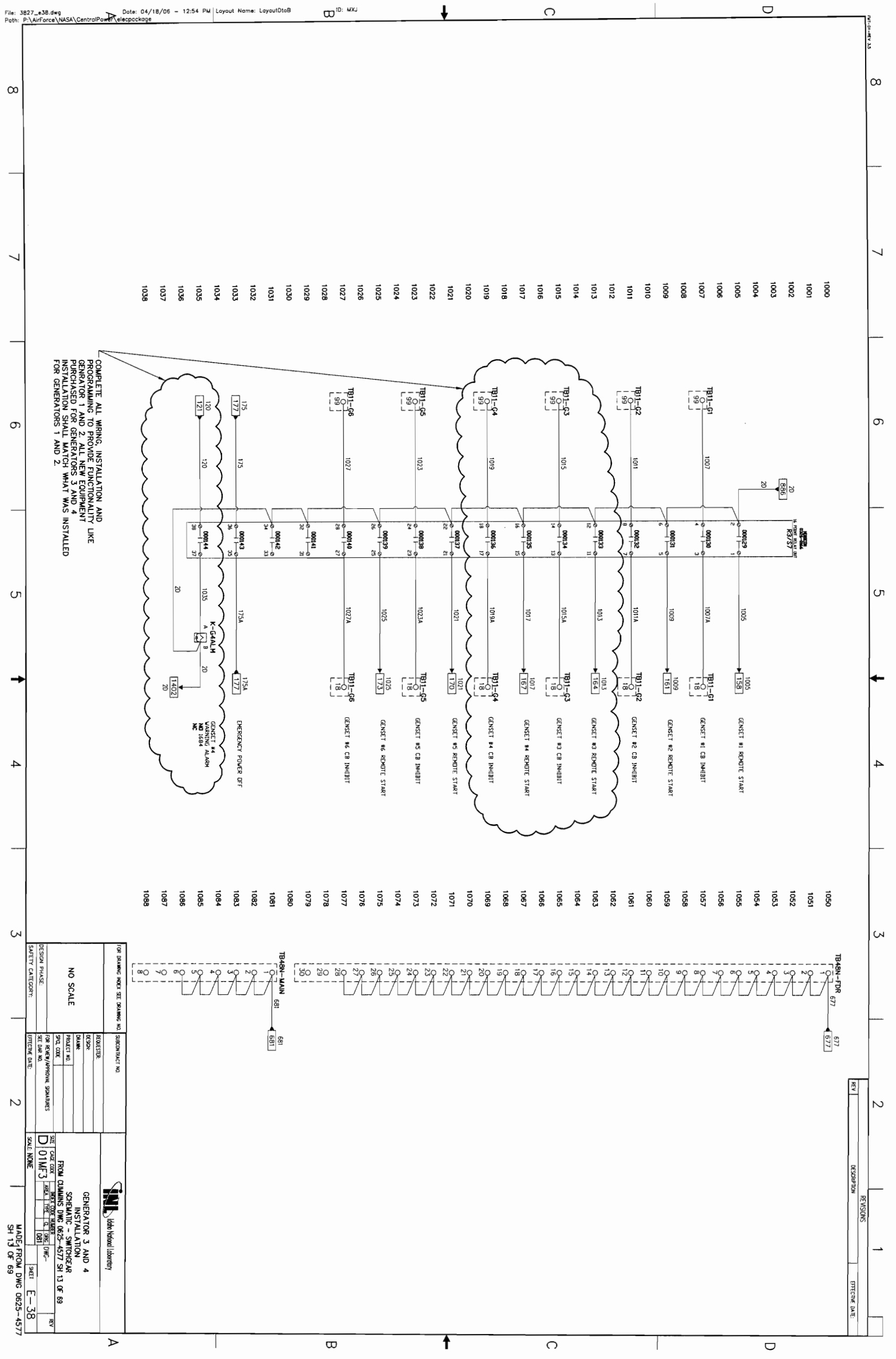




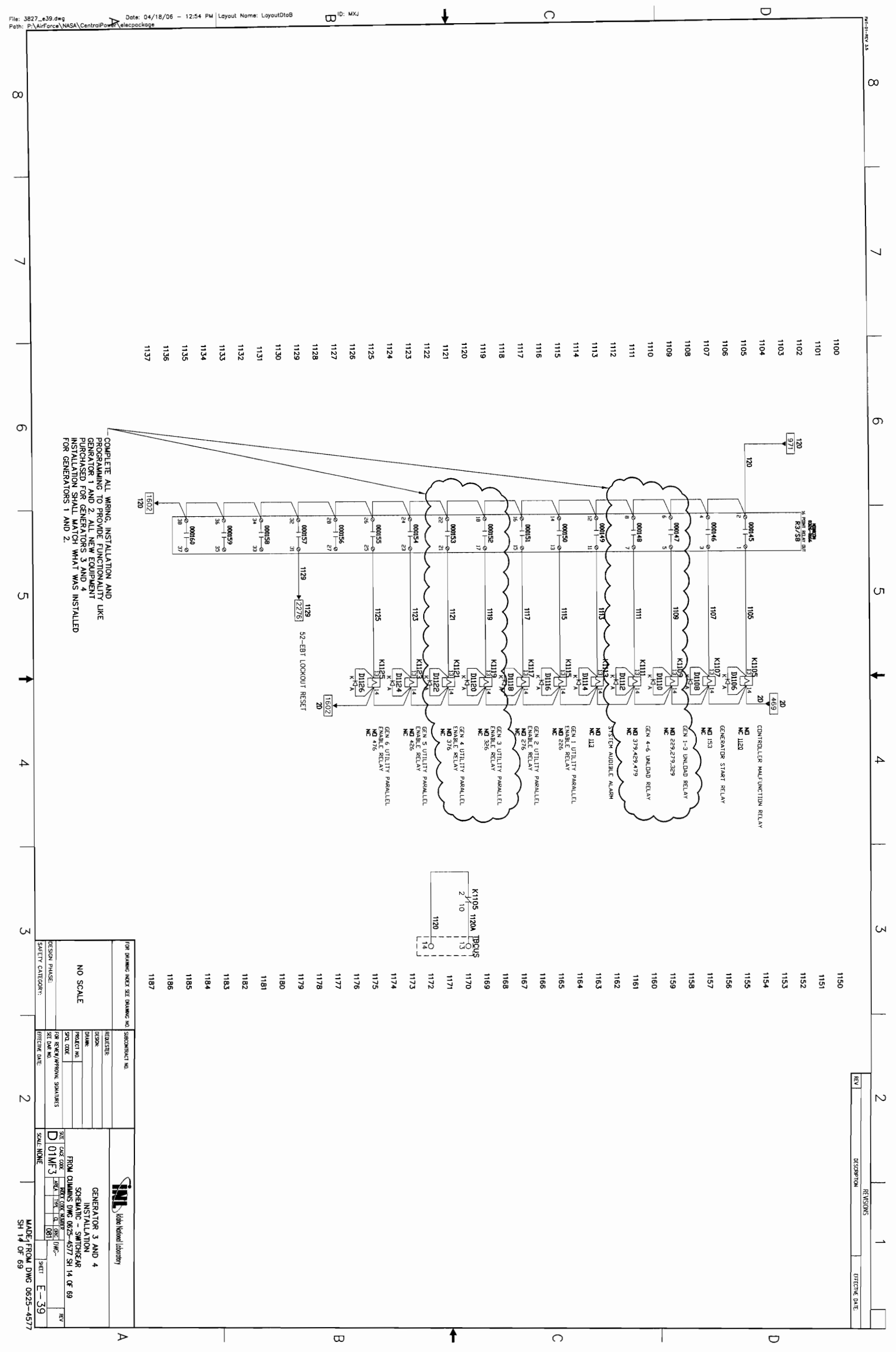




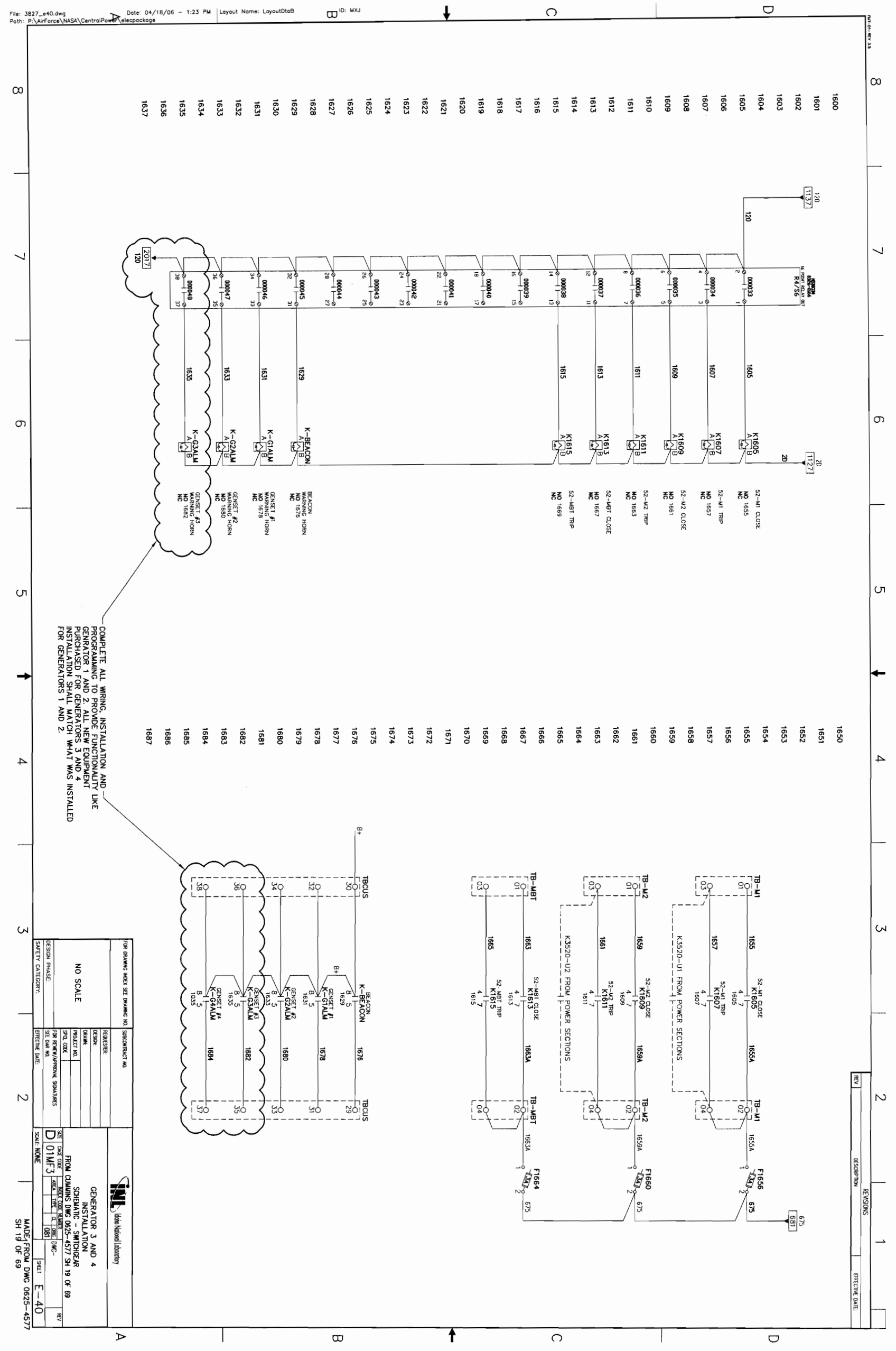




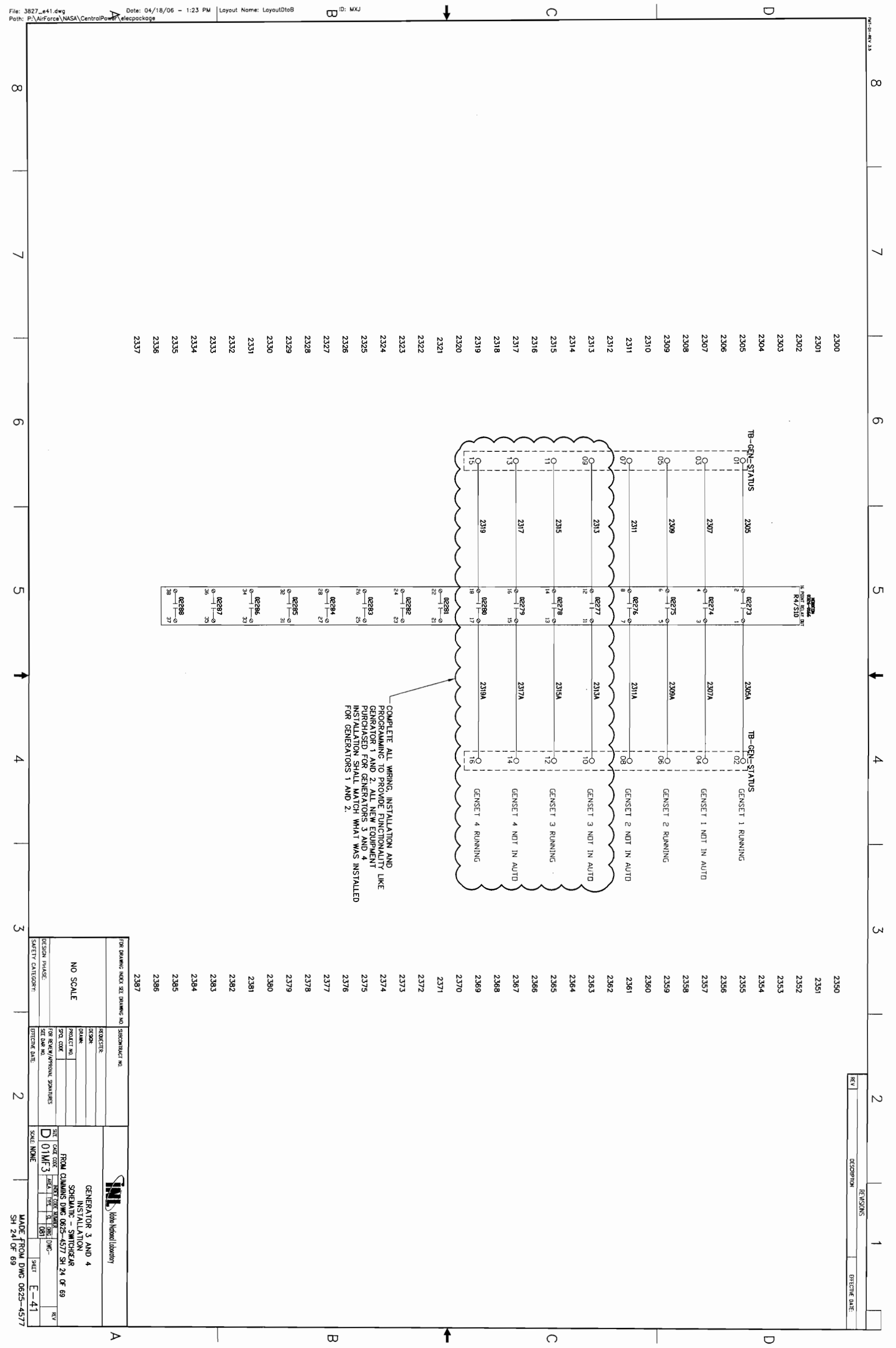




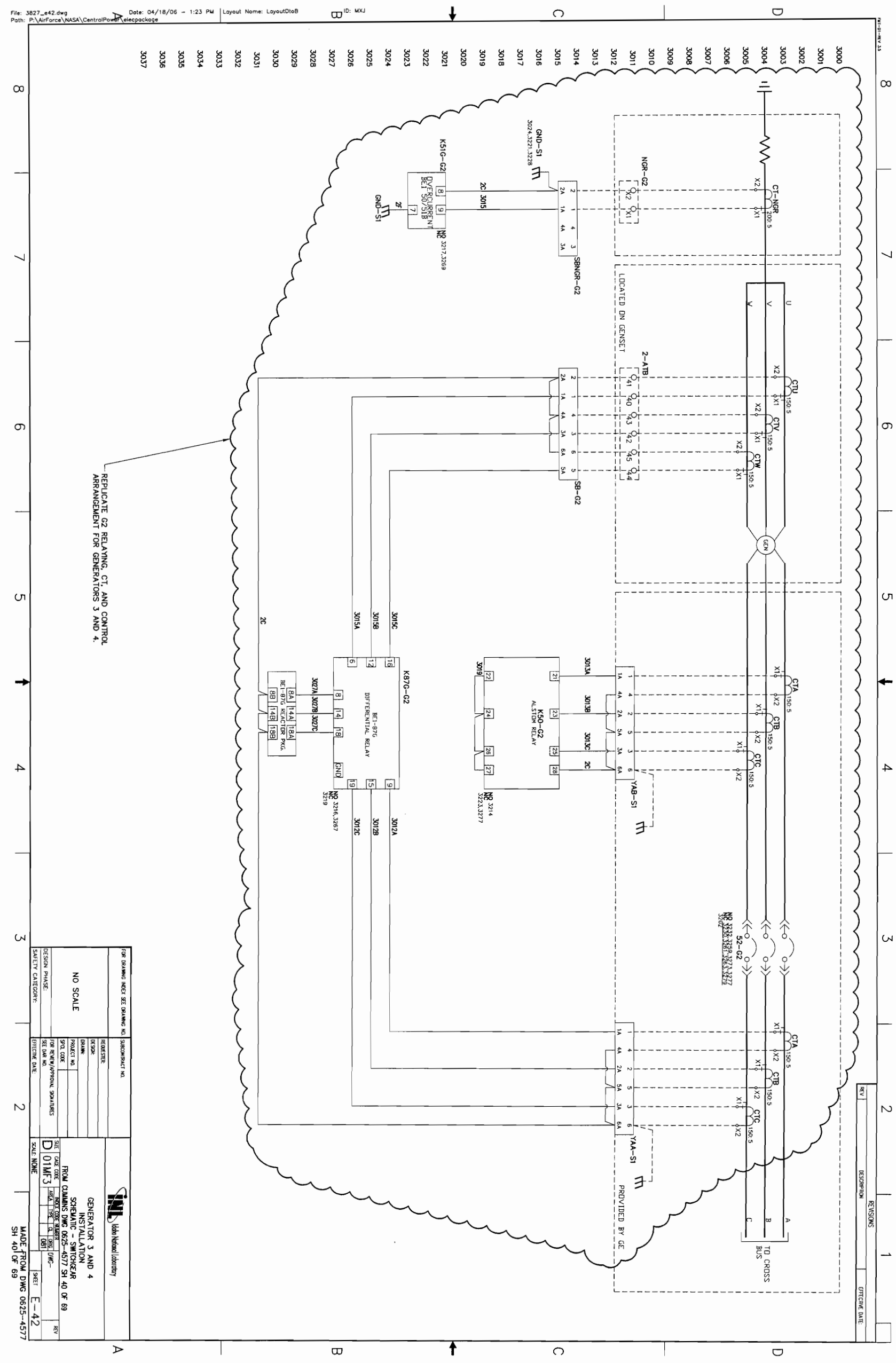




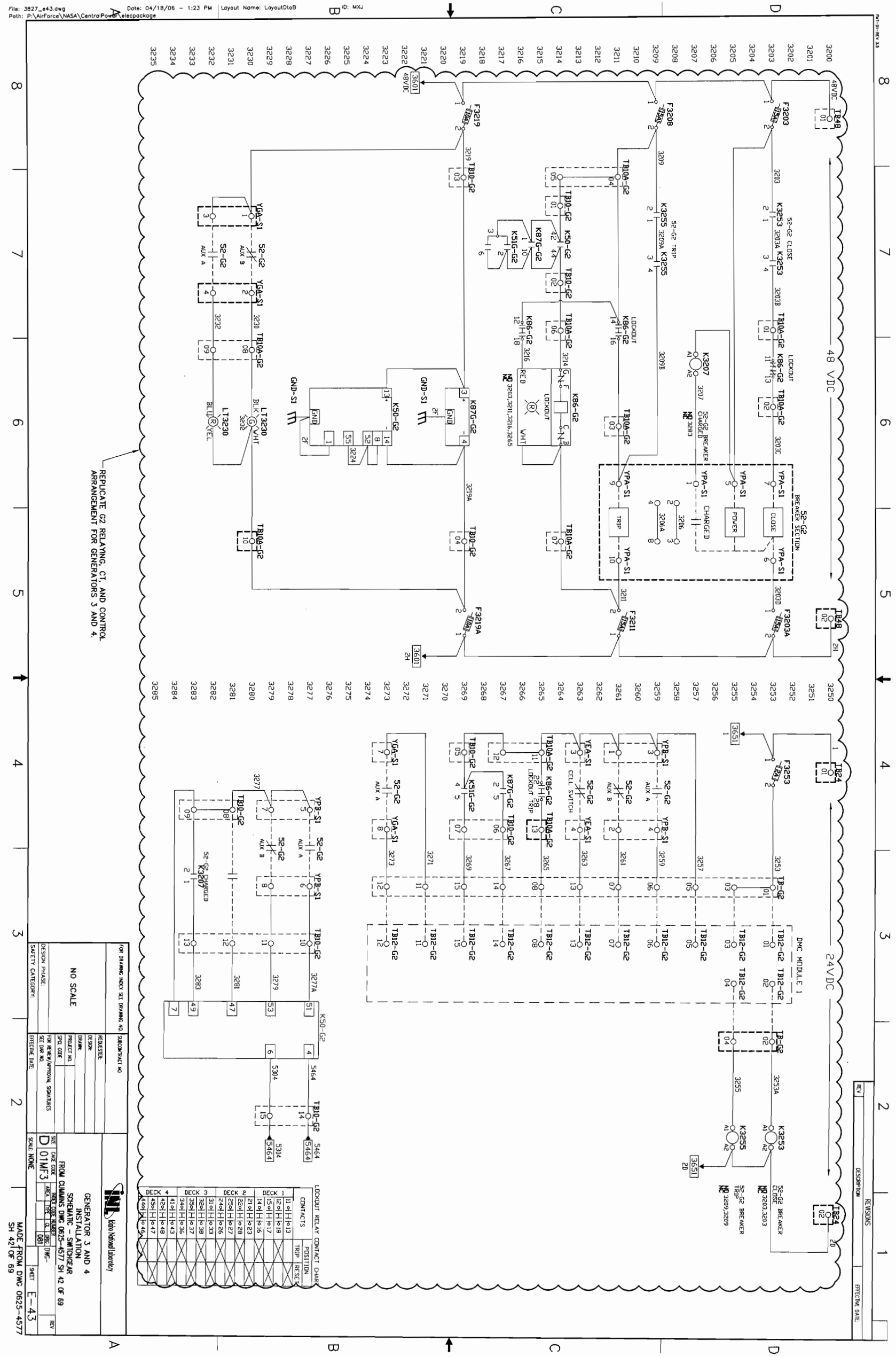




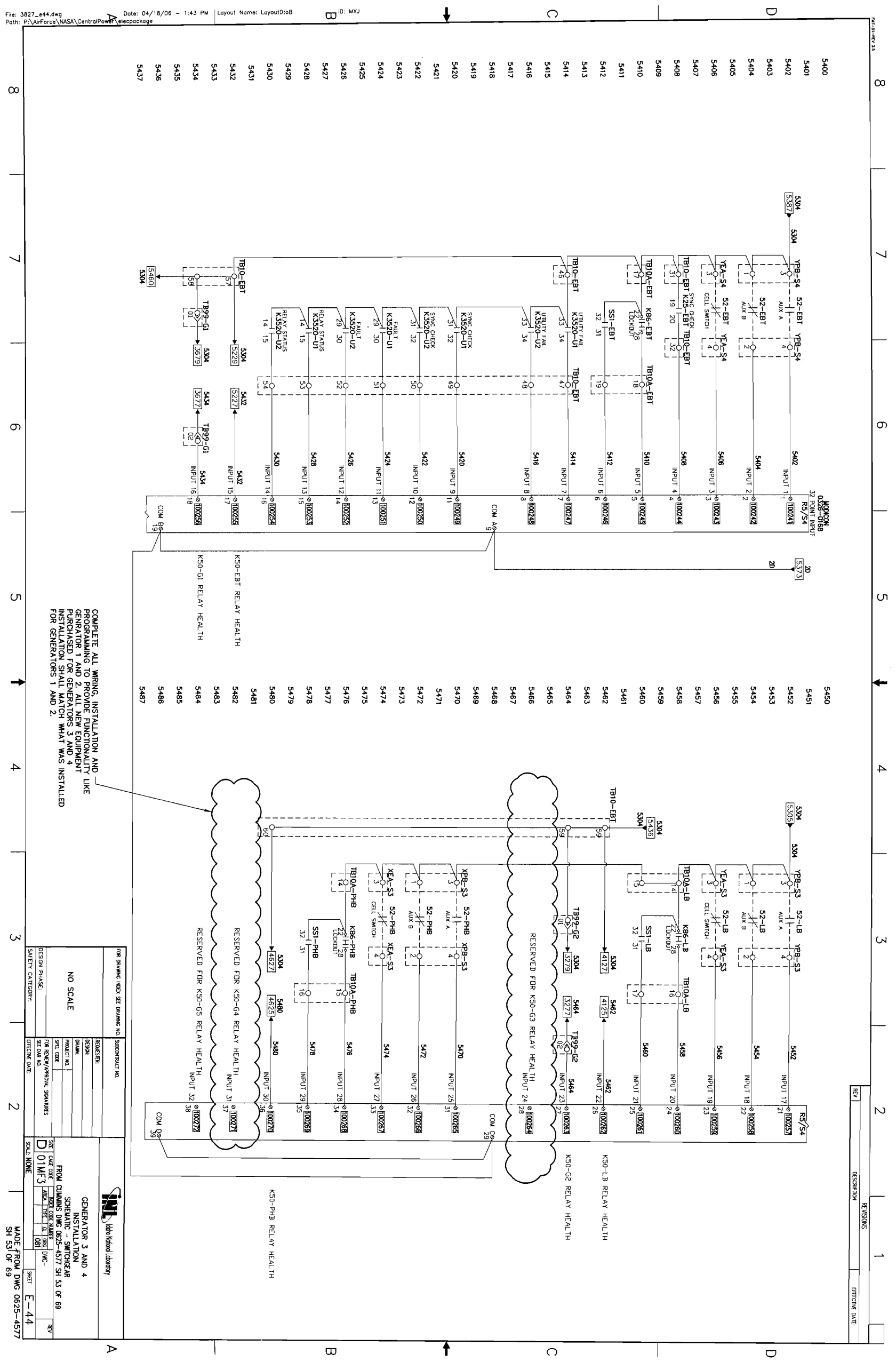




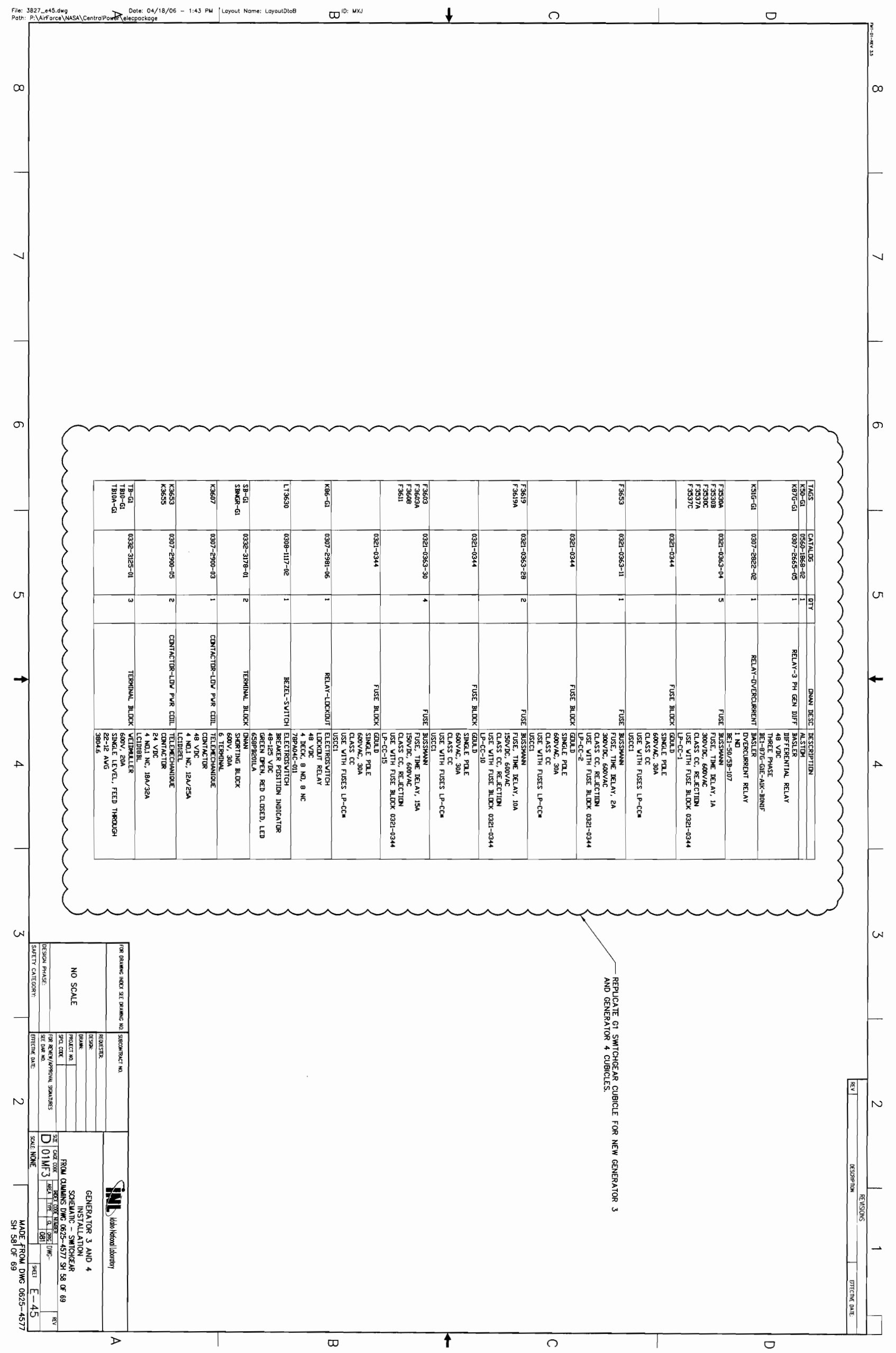




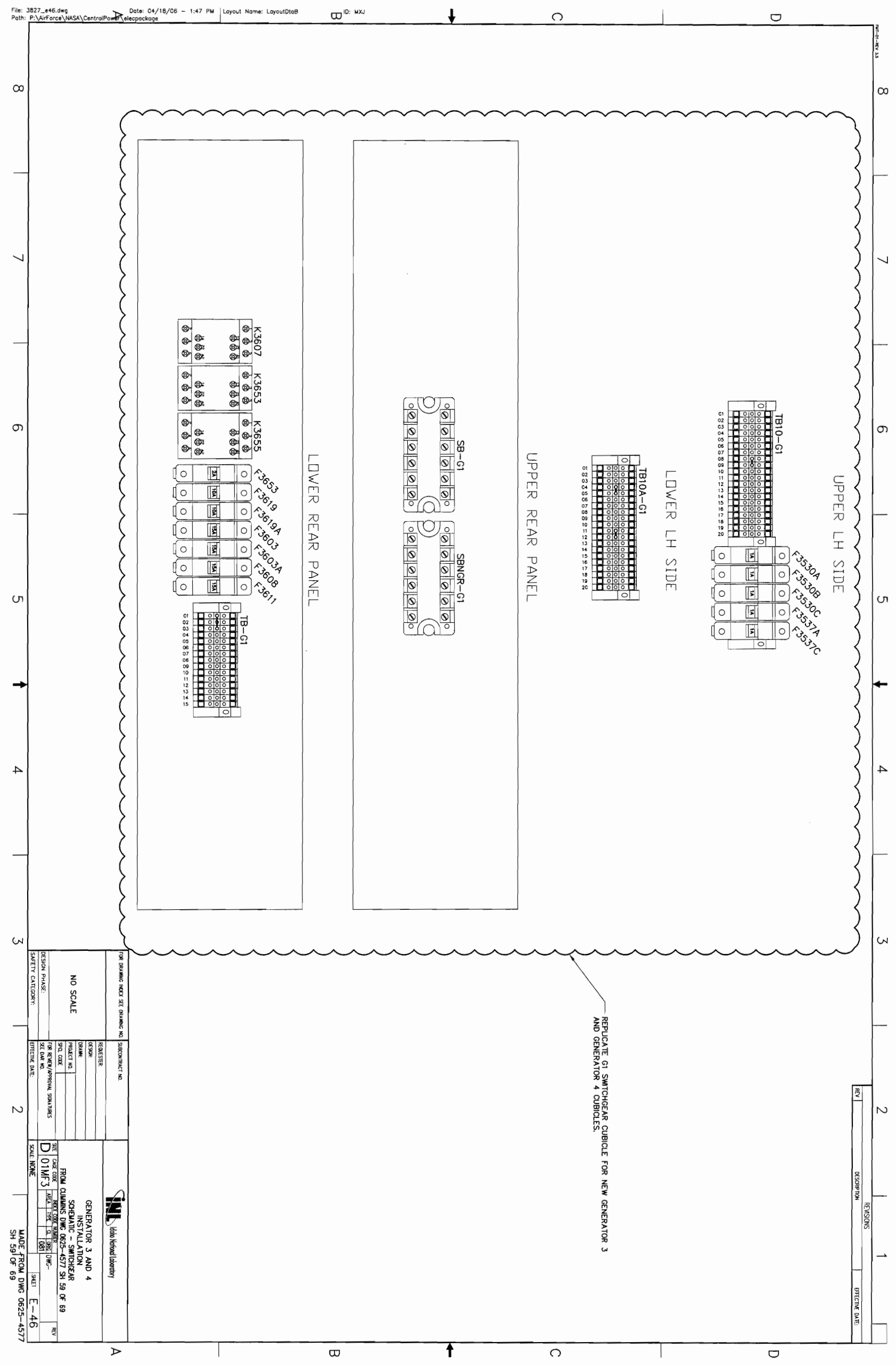




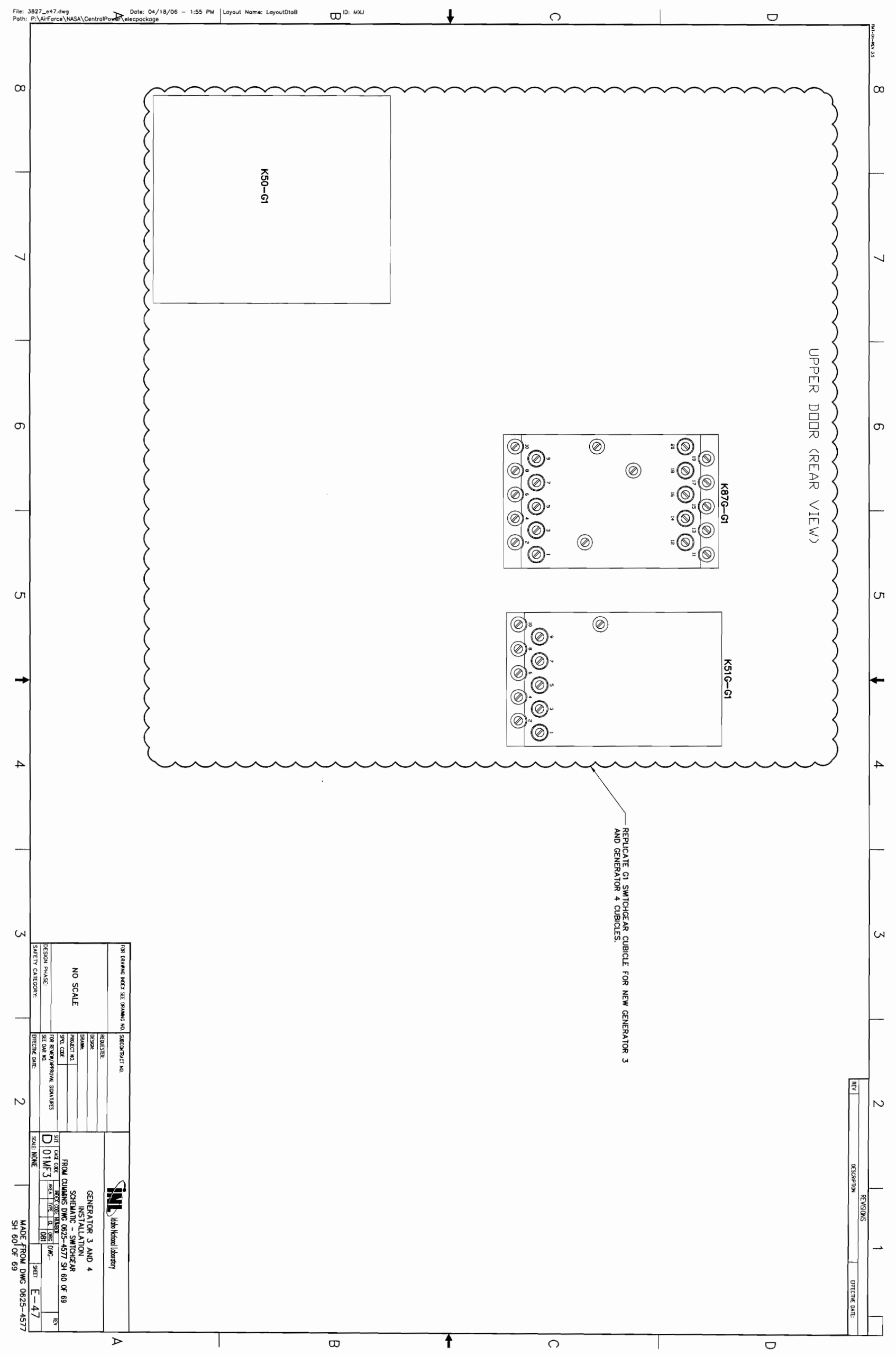




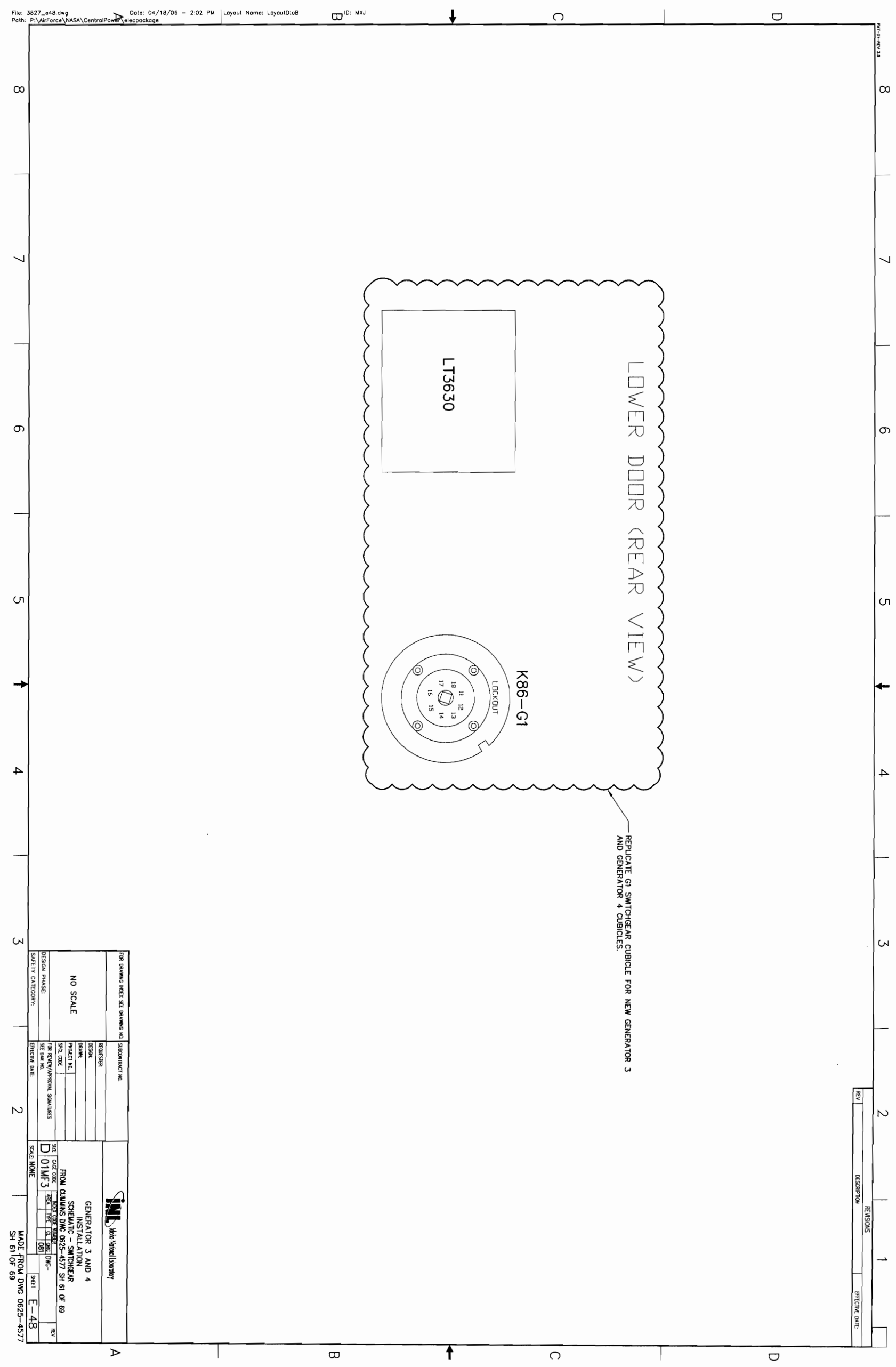




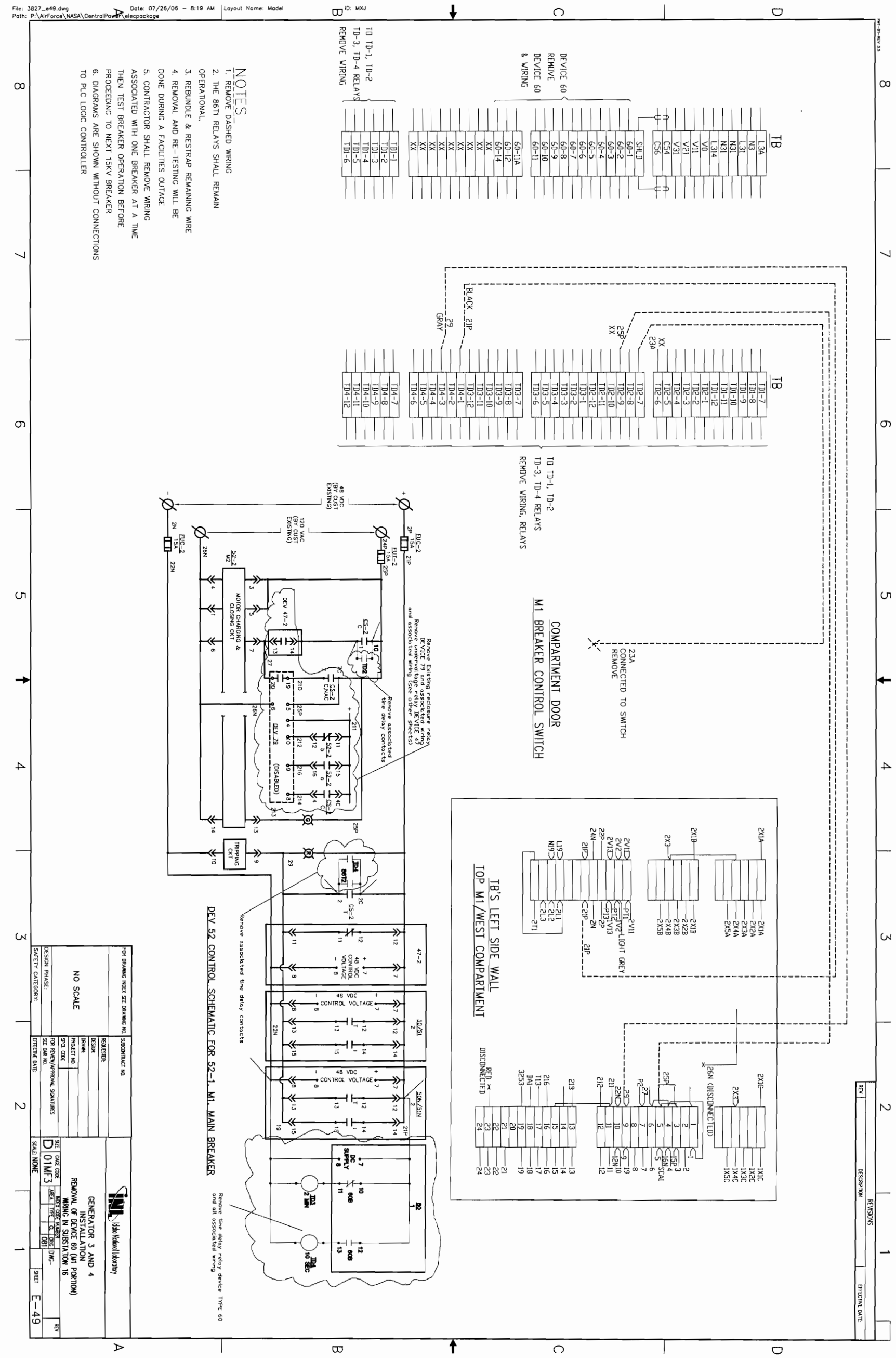




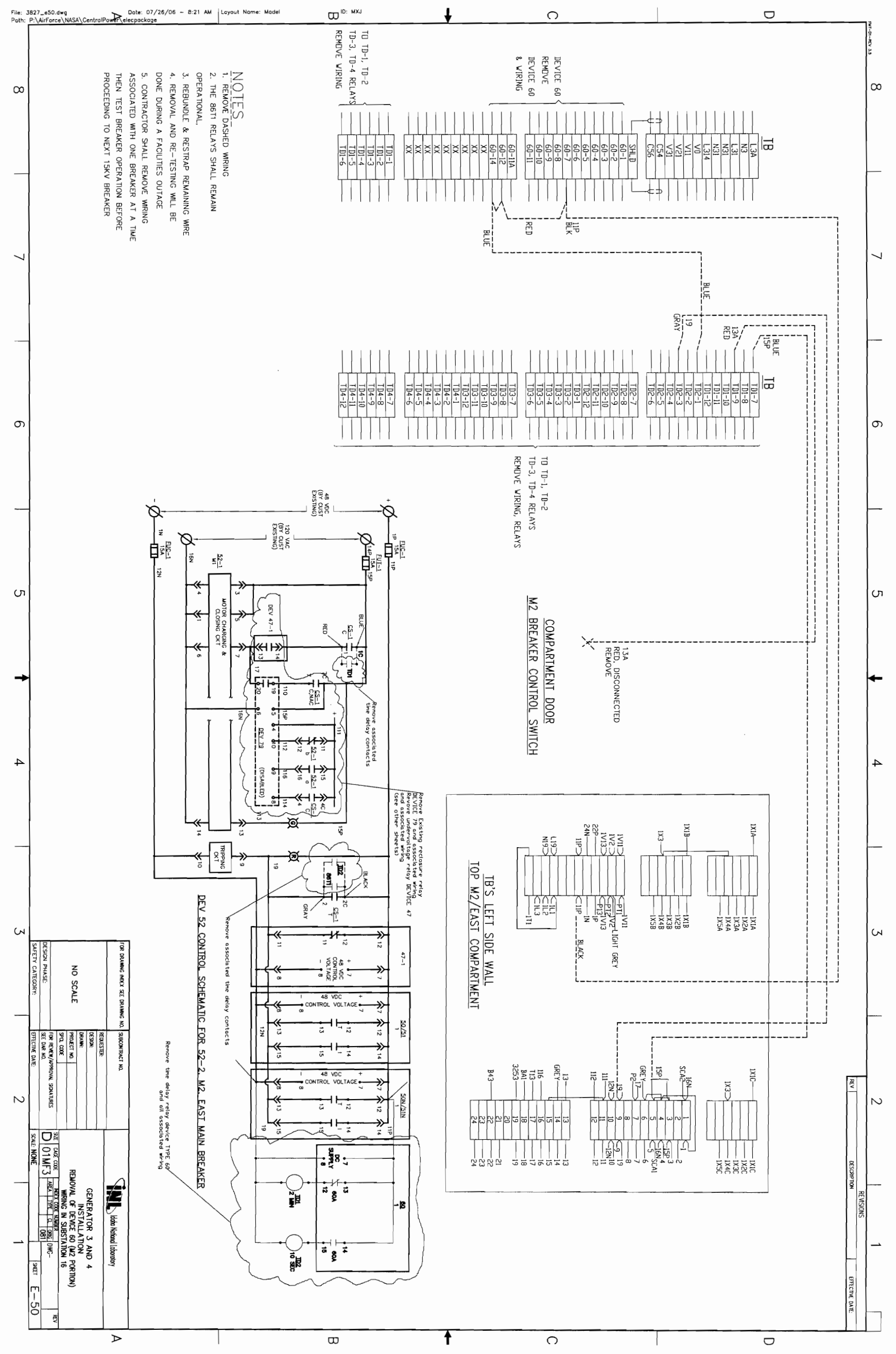




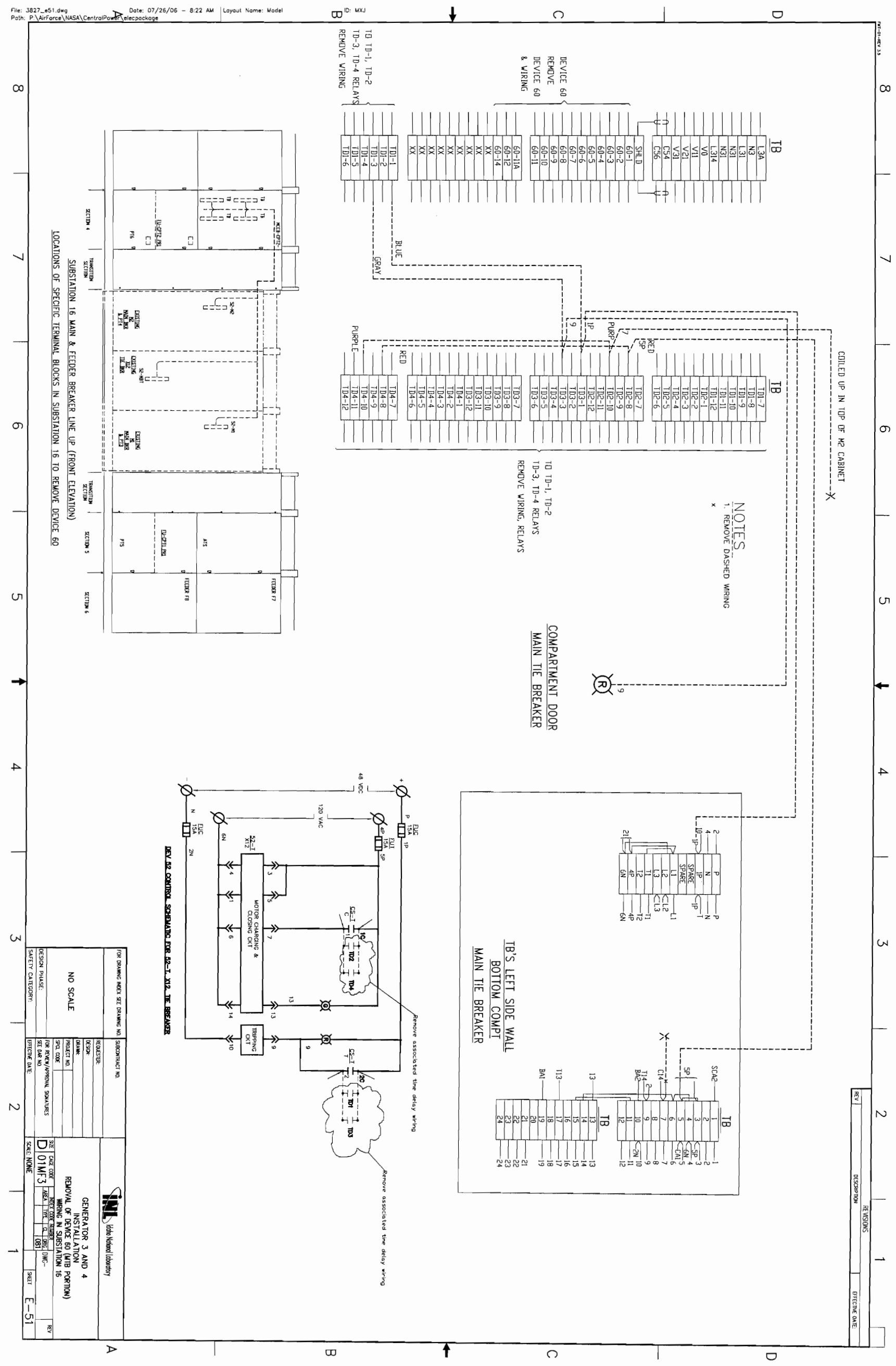




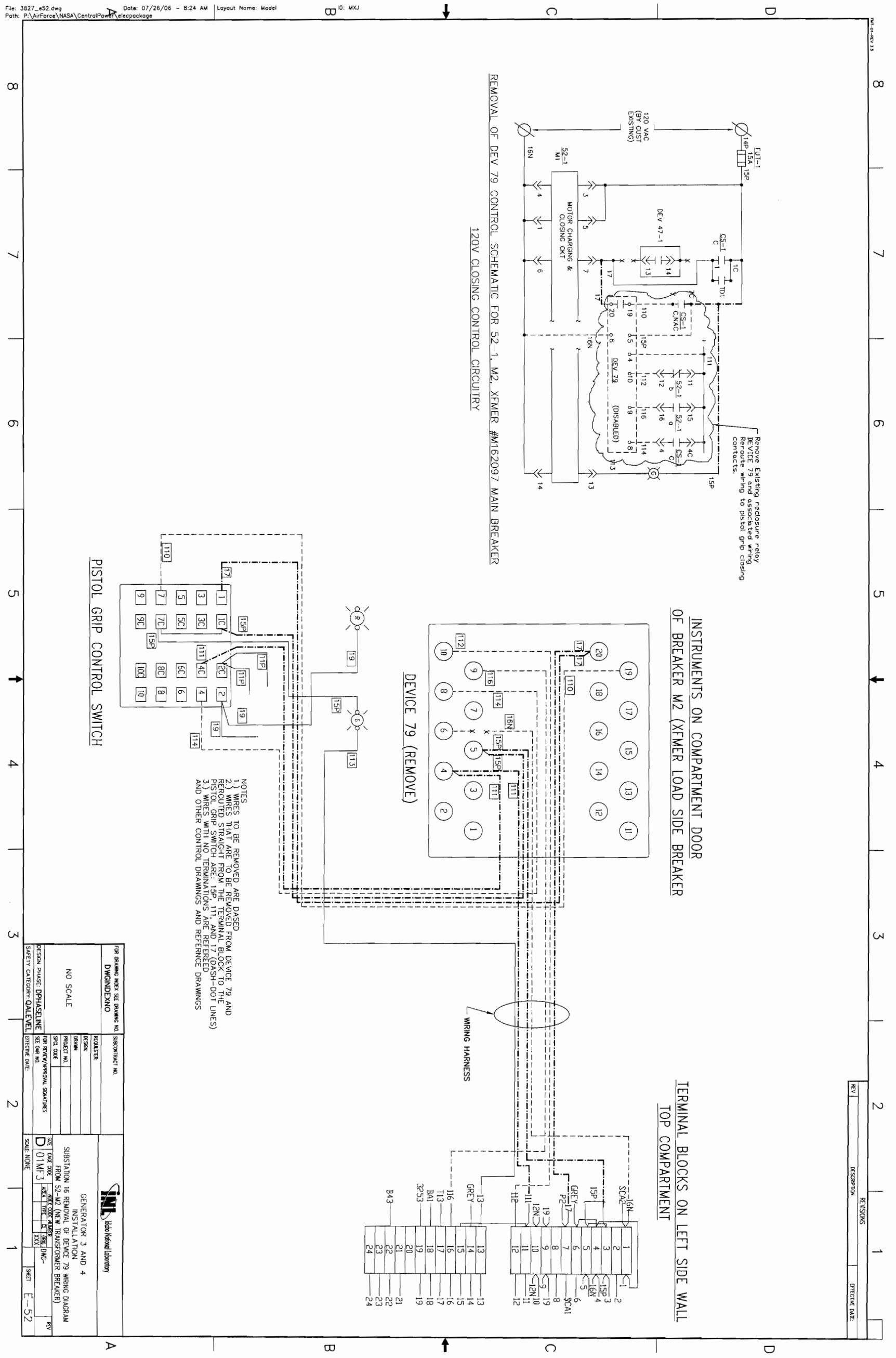




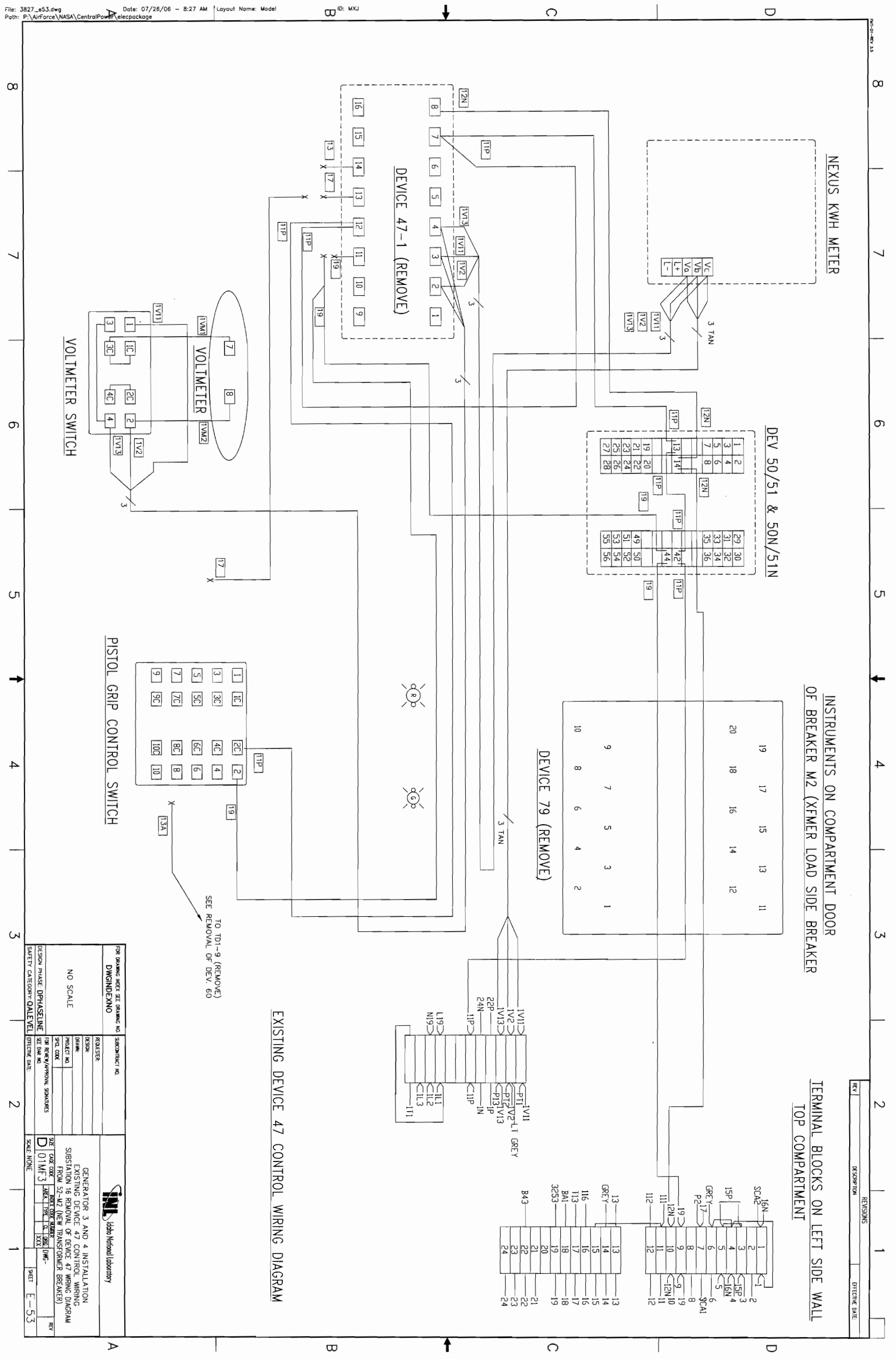




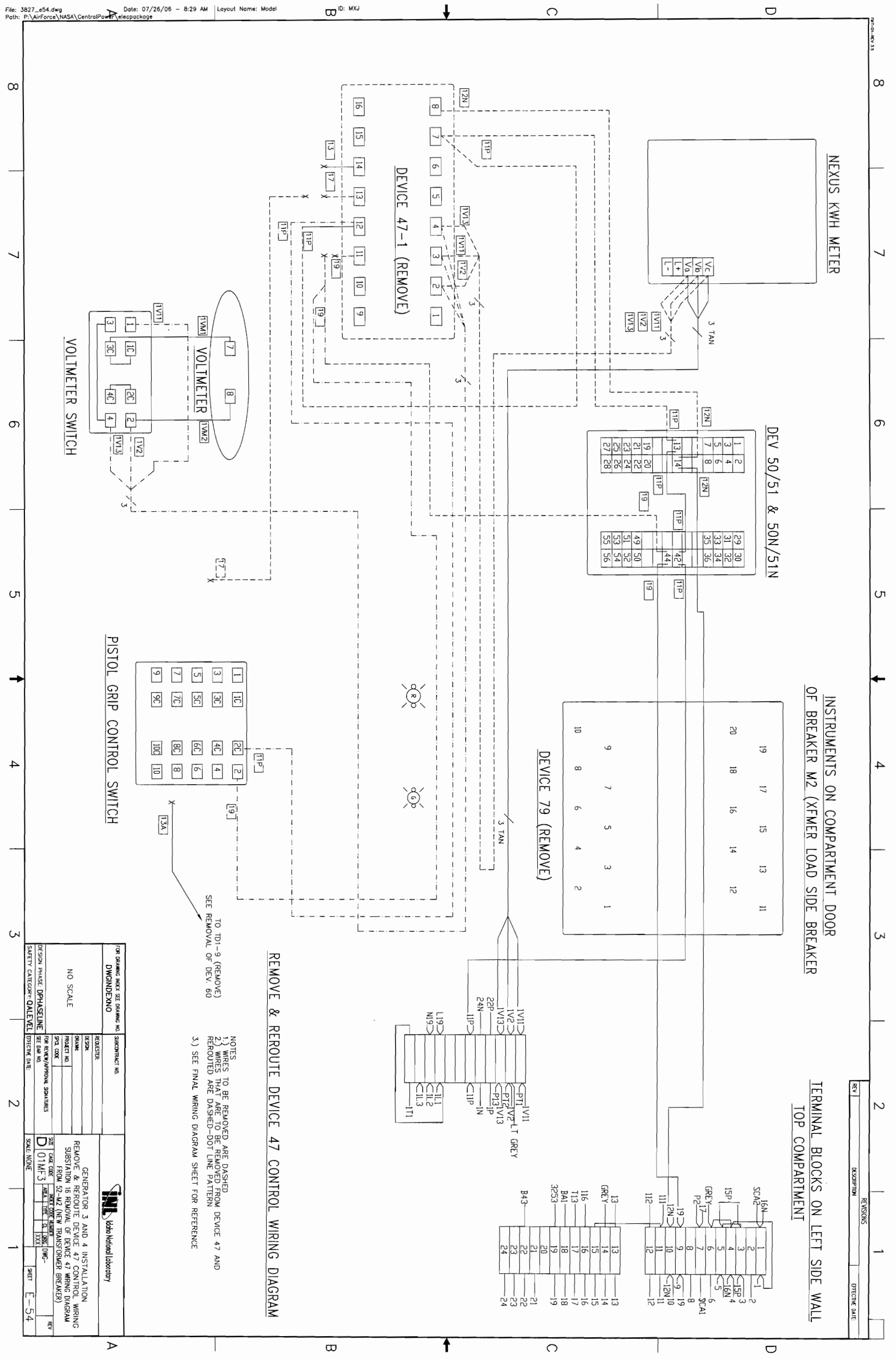




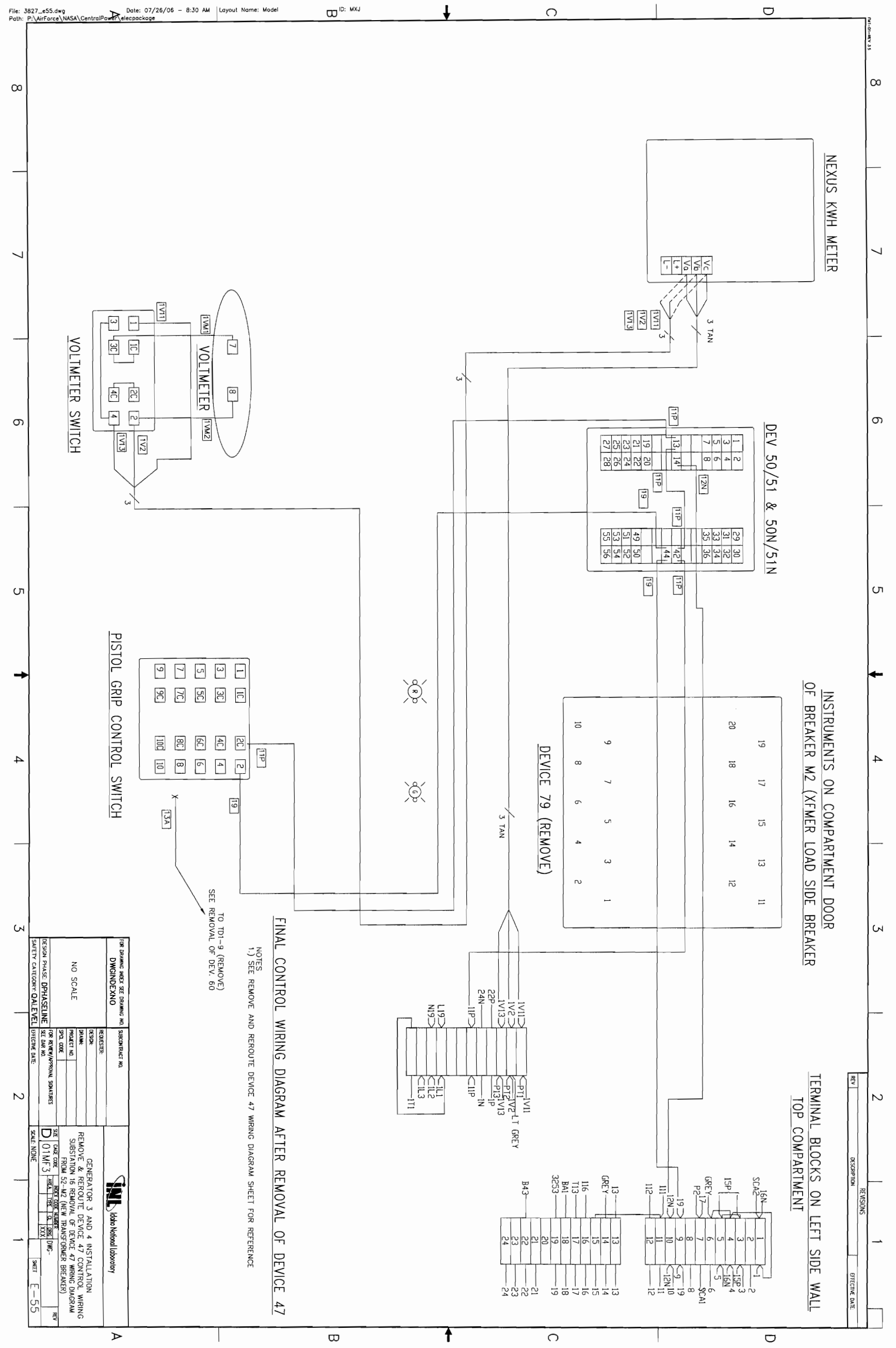




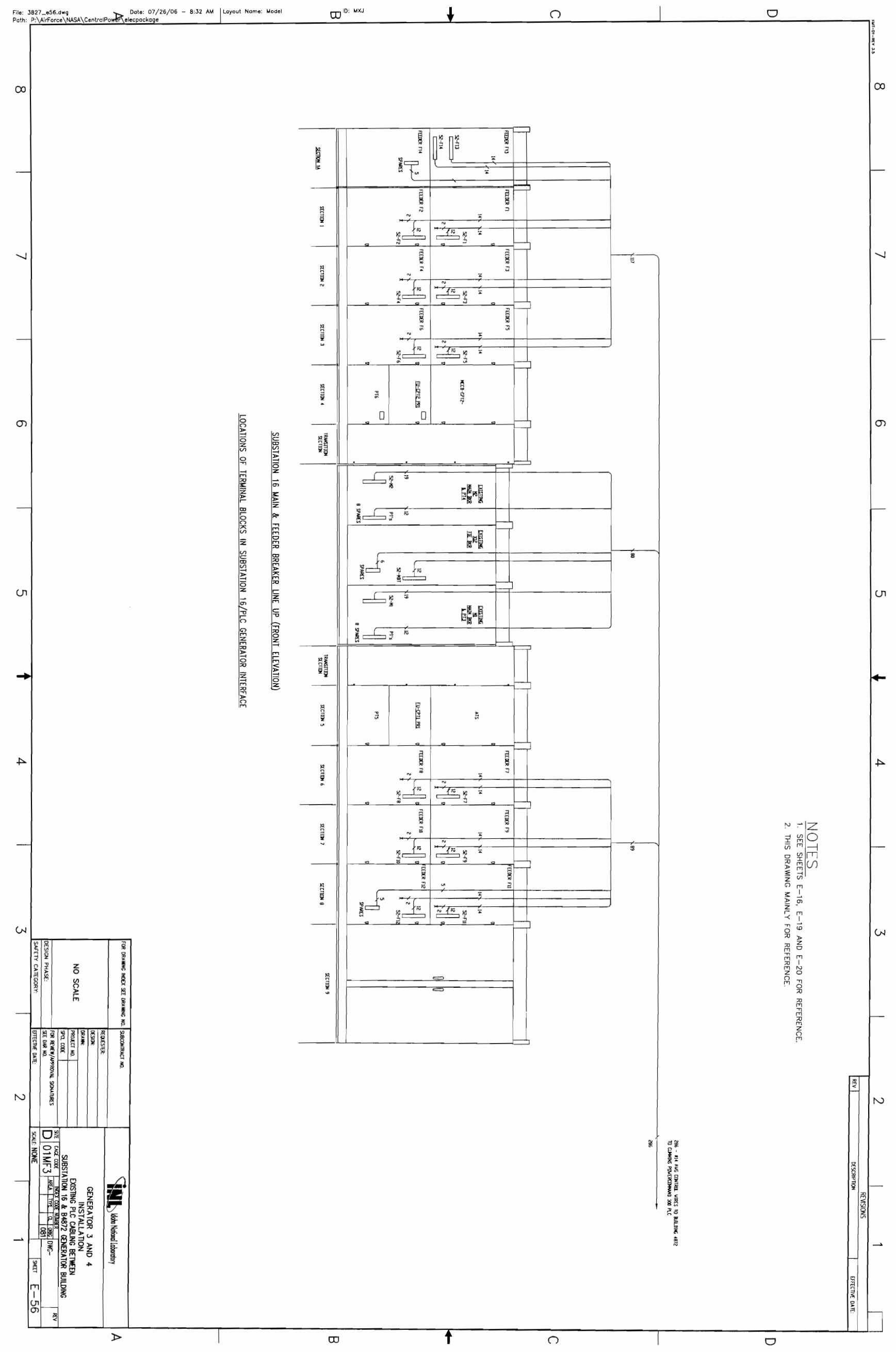

